\title{
Setting a Regulated Suction Pressure for Endotracheal Suctioning: a Systematic Review
}

David Arbon

Student number 1214862.

Master of Clinical Science candidate

The Joanna Briggs Institute.

Faculty of Health Sciences

The University of Adelaide, S. Aust. 5005.

david.arbon@adelaide.edu.au

Thesis submitted October 2011

Supervisors

Prof. Judy Lumby AM, RN, PhD, MHPEd. BA, FCN (NSW), FRCNA.

Dr. Catalin Tufanaru MD, MPH. 


\section{Table of Contents}

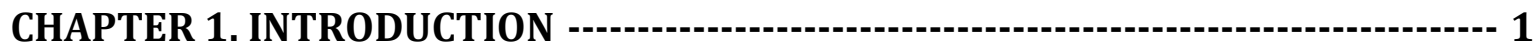

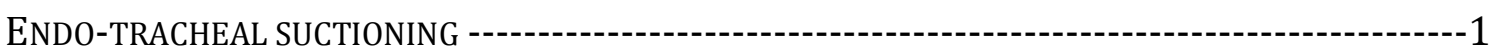

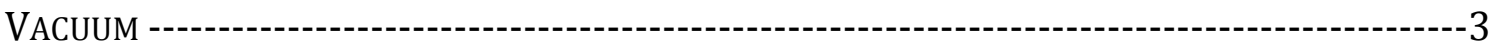

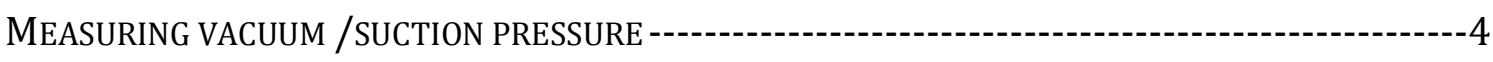

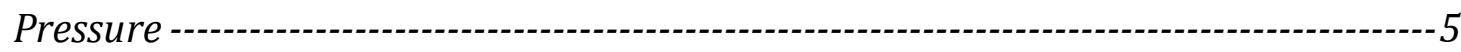

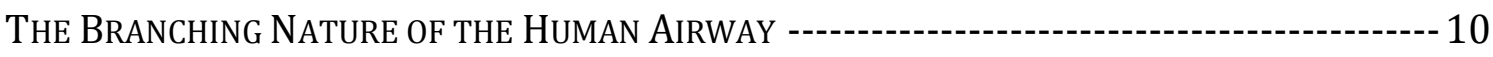

CHAPTER 2. SYSTEMATIC REVIEW PROTOCOL -

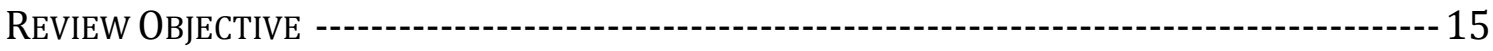

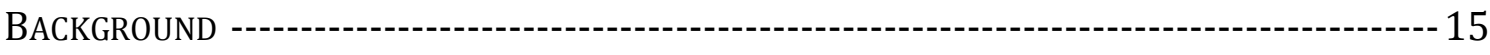

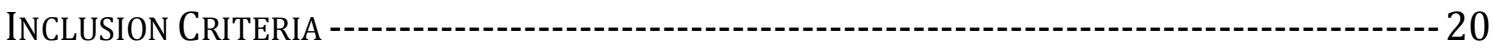

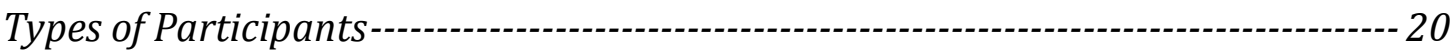

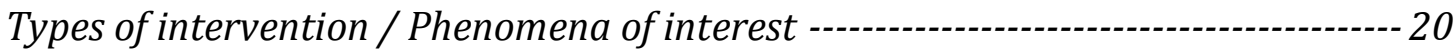

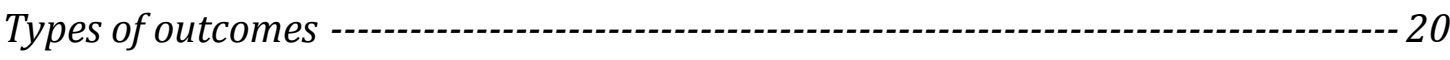

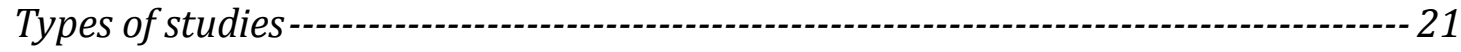

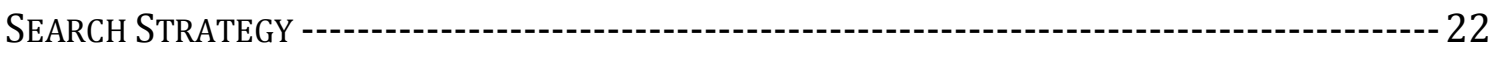

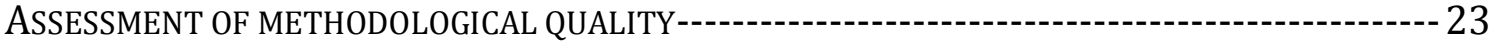

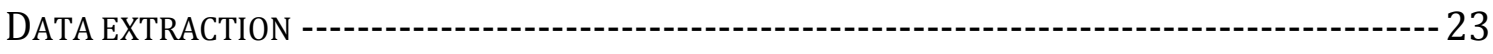

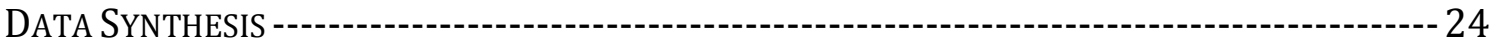

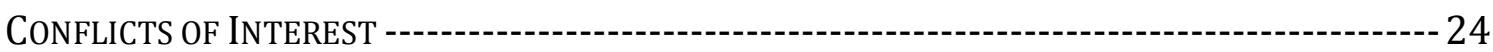

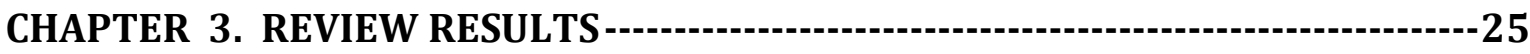

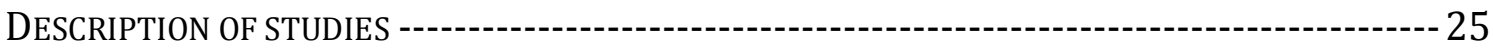

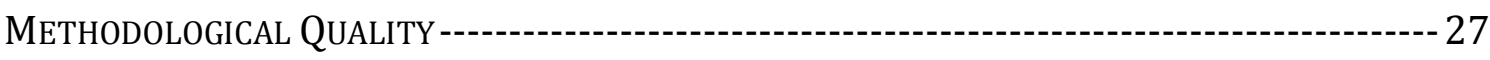

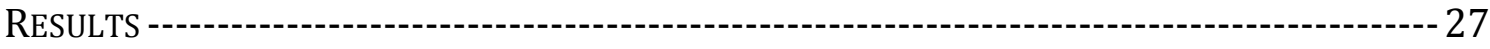

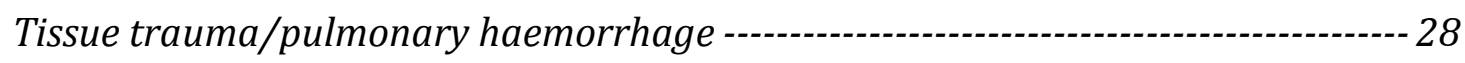

Atelectasis, Loss of Volume, Segmental Collapse--------------------------------- 28

The Haemodynamic effect of negative intra pulmonary pressure ------------------- 34

Benefits of regulating vacuum exposure versus no regulation/free flow ------------ 36

CHAPTER 4. DISCUSSION--- 37

DISCUSSION OF ANIMAL STUDIES AS BACKGROUND TO REVIEW QUESTIONS --------------------- 37

Tracheobronchial Trauma---.-- 37

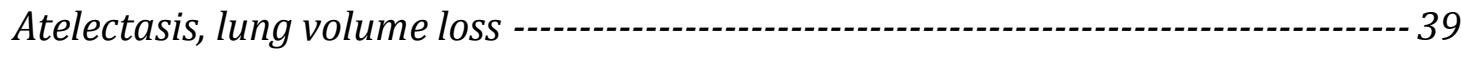

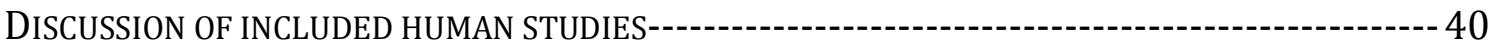

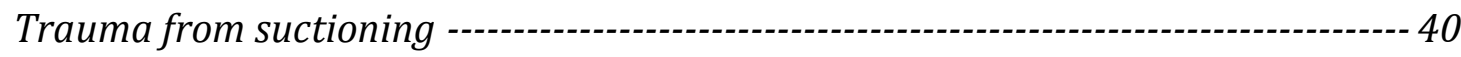

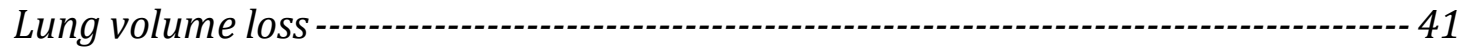

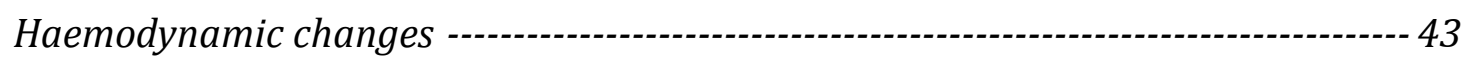

Limitations of the review

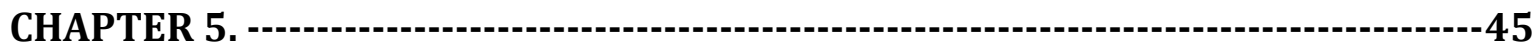

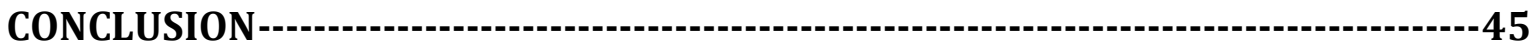

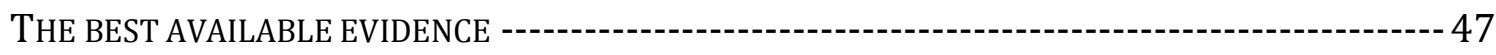

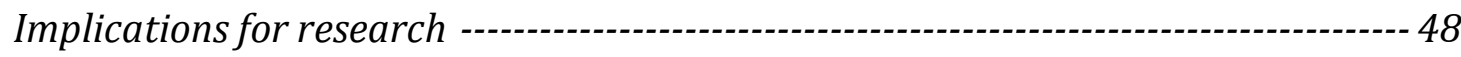




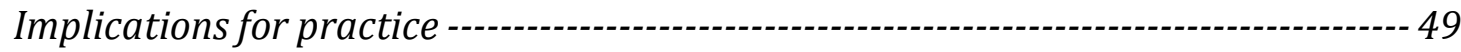

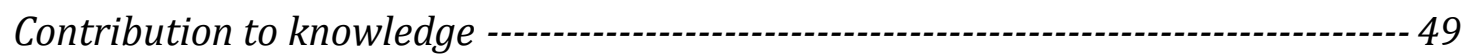

APPENDICES --- 50 


\section{Figures and Tables}

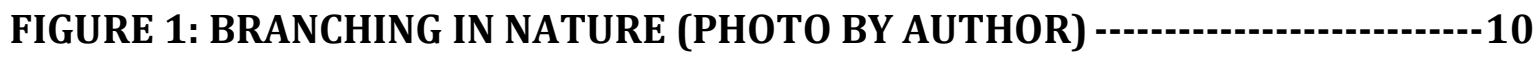

FIGURE 2: CT SCAN OF THE HUMAN AIRWAYS (PHOTO BY AUTHOR) --:-------11

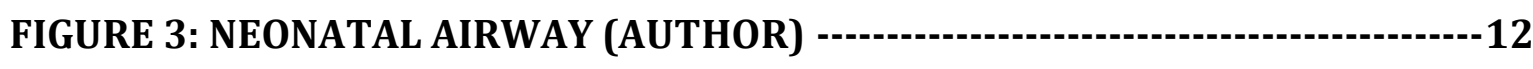

FIGURE 4: HIGHLIGHTING THE NARROWING OF AIRWAYS (ILLUSTRATION BY

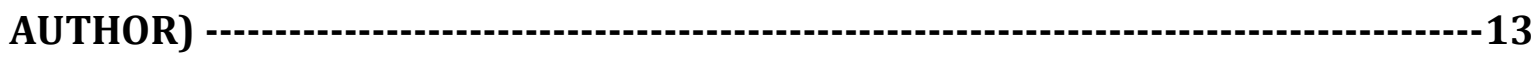

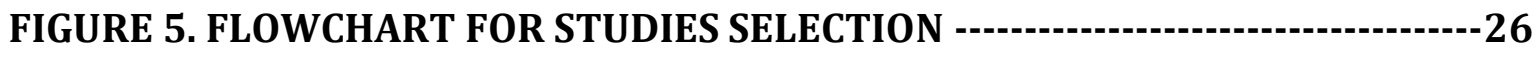

TABLE 1.VOLUME LOSS FROM SUCTIONING -

TABLE 2. FLOW RATES THROUGH SUCTION CATHETERS AT REPORTED

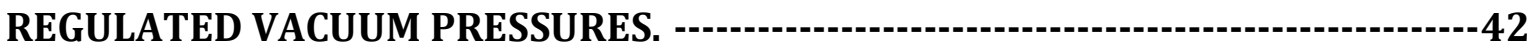




\section{Abstract}

The Thesis has set out to synthesise a recommendation with regard to the setting of a safe yet effective vacuum/suction level, for the performance of endotracheal suctioning of intubated and mechanically ventilated patients in the acute care environment, from a systematic review of human studies.

Specifically the systematic review has sought to answer the following questions:

- What is the best evidence for regulating vacuum pressure in the performance of endotracheal suctioning?

- What is the best evidence for regulating vacuum pressure for endotracheal suction as opposed to setting no regulated pressure in the performance of endotracheal suctioning?

- What is the best evidence for a limit to which vacuum should be regulated for endotracheal suction?

- To what extent does the developed airflow impact on the safety and effectiveness of the suction apparatus?

We have first examined the delivery of suction to the patient by examining hospital suction systems and the physics of suction/vacuum before a review of the relevant anatomy of the human airway and how these may affect one, the other.

While the Systematic Review has focused on extracting data from studies of the effect of setting a regulated suction/vacuum pressure in human subjects, it was found that, in order to provide the best available evidence, the discussion necessarily incorporated the findings of animal and bench test experiments as these underpin the research in this area. It is impossible to neglect the effects of physics and the mathematical certainty of negative pressures developing in the chest at various levels of increasingly negative suction pressure. 
The systematic review included 30 primary research quantitative papers with regard to human subjects in which a level of suction was described as well as variables such as loss of lung volume, trauma or haemodynamic changes. These were examined with regard to extracting outcomes of significance.

It has been due only to the heterogeneous nature these human studies that they have, on the whole, been found unsuitable for pooling into a meta-analysis. However, there remains, within the published literature, a remarkable degree of consistency. It is for this reason that results have been presented as a narrative summary.

\section{Conclusion}

Despite the heterogeneous nature and small scale of much of the research into this subject, findings support and give weight to those recommendations laid out in previous metaanalysis and reviews of the endotracheal suctioning process. An optimal level of vacuum is that which is the lowest that will achieve clearance of retained secretions whilst minimising disruption to ventilation: "As little as possible/as much as necessary." Negative pressures of $80-100 \mathrm{mmHg}$ in neonates and less than $150 \mathrm{mmHg}$ in adults have been recommended. This review has found flows of 15 to 20 litres of air entrained though a suction catheter described as sufficient to perform the procedure. While no safe maximum has been determined; there is no evidence to support suctioning an artificial airway from an unregulated wall suction outlet. 


\section{Student declaration}

This work contains no material which has been accepted for the award of any other degree or diploma in any university or other tertiary institution and, to the best of my knowledge and belief, contains no material previously published or written by another person, except where due reference has been made in the text.

I give consent to this copy of my thesis, when deposited in the University Library, being available for loan and photocopying.

Signed.

David Arbon. 


\section{Ex diuturitate temporis omnia praessumuntur esse solemniter acta.}




\section{Chapter 1. Introduction}

\section{Endo-tracheal suctioning}

Endo-tracheal suctioning, an essential component in the management of airway patency and secretion removal in the critically ill, has become a routine part of care for mechanically ventilated patients in the Intensive Care Unit. ${ }^{1,2}$

Towards the end of 2008 it occurred to me that the unguarded wall suction outlet could present a negative pressure to the lung, equivalent to the suction occlusion pressure of the outlet under certain circumstances.

These outlets can develop a suction occlusion pressure of up to minus $600 \mathrm{~mm} \mathrm{Hg}$ or $80 \mathrm{kPa}$., and a flow rate of more than 80 litres/minute in keeping with the appropriate Australian Standard.

A discussion ensued in which I was assured that we had taken our suction for endotracheal suctioning directly from the wall suction outlet for more than thirty years and observed no suction related adverse events.

Ex diuturitate temporis omnia praessumuntur esse solemniter acta. Or perhaps, everything that has been done for a long time is presumed to have been done in good order.

Nevertheless an examination of some clinical guidelines and contact with Joanna Briggs Institute as well as my old nursing textbook soon alerted me to the fact that it was if fact common advise to set a regulated suction pressure of not more than some $150 \mathrm{~mm} \mathrm{Hg}$. in the adult patient and less than $80 \mathrm{~mm} \mathrm{Hg}$. in the case of small children, prior to performing this routine procedure.

Naturally this presented an opportunity to look more closely at the question of pressure setting and its origins by way of a Systematic Review of the original research. 
The artificial airway mechanically disrupts the muco-cilliary escalator resulting in a pooling of secretions below the endotracheal tube that will need to be removed by the suction catheter ${ }^{1,2}$. Furthermore the Endotracheal (ET) tube itself is inclined to become occluded with bio-films after a short period insitu ${ }^{2}$, making it necessary to perform this suctioning of the airway to keep the airway patent and remove respiratory secretions as part of the care of the intubated patient.

Various risks are involved in the procedure since the earliest days of invasive respiratory support including "death by suctioning". ${ }^{3}$ These risks include:

- Atelectasis; Reported and shown by radiological exam as early as the 1940 's ${ }^{3-5}$

- Pulmonary haemorrhage has been seen with rapid decompression of segmental lung, with mechanical trauma from catheter impaction or sudden explosive decompression. ${ }^{6-8}$

- Tissue trauma has been reported from the vigorous insertion of the suction catheter or impaction as the tissue lining the airway is suctioned into the side ports of the catheter. ${ }^{6,9,10}$

- Negative pressure pulmonary oedema may be a result of the negative intrapulmonary pressure across the alveolar capillary bed.

A collection of systematic reviews, meta-analyses, and guidelines and their recommendations as to pressure setting is appended (Appendix I), and relevant references extracted from these existing publications are appended (Appendix VII). These reviews, meta-analyses and guidelines were examined with regard to the current recommendations for practice and the level of evidence reported to support those findings. Details on existing animal studies that inform the human studies may be found in Appendix IV. 


\section{Vacuum}

\section{Nattura abhorrent a vacuo}

Nature, we are told, abhors a vacuum but what is it and how does nature attempt to remove it.

A vacuum for our purposes exists when the pressure of air or fluid is reduced in relation to that elsewhere. The gas or fluid will flow from an area of high pressure to an area of lower pressure to restore equilibrium in the system under examination. ${ }^{11}$

Galileo Galilei was among the first to consider the practical effects of vacuum in the seventeenth century, when it had been discovered that suction pumps used in mines and irrigation at the time would not lift water more than about 10 meters. ${ }^{12,13}$

Galileo's student Torricelli around 1643, began experimenting with the idea of vacuum by removing air from a sealed chamber, bell jar, he developed the first mercury barometer and described the vacuum formed at the top and how the atmospheric pressure acted to support the column of mercury. Forming the basis of many of the theories of pressure and gas laws we know today. ${ }^{11}$

The vacuum pump as we know it today is considered to have been invented by Otto Von Guericke in 1654. He is better known for the Magdeburg hemispheres held together by a partial vacuum such that horses could not separate them and the subsequent pictures of this feat appearing in school science books since. Further experiments by Robert Boyle (25 January 1627 - 31 December 1691) along with Robert Hooke (18 July 1635 - 3 March 1703) helped define the properties of vacuum. It was 1855 before Heinrich Geissler conducted further investigations creating a record level of negative pressure in a sealed chamber and renewing interest in the potential of vacuum that lead to the development of the electrical vacuum tube. ${ }^{11}$

The blades of the fan in a vacuum cleaner will reduce the air pressure in the hose by removing air maintaining a negative pressure at the nozzle relative to the atmosphere. This flow of air will draw, or rather push, dust and particles into the hose of the vacuum cleaner. The movement created is the suction pressure. 


\section{Measuring vacuum /suction pressure}

As with most human endeavours it seems we, once again, are unable to all speak and understand the same language. Historically pressure has been measured in units that were for the most part linked with their application. The people who went to Galileo for advice found they had trouble lifting water to a height over 32 feet (10 meters) and couched their irrigation problem in feet of water.

Torricelli found mercury a medium where less volume could measure higher or lower pressures more conveniently. The unit of measurement representing millimetres of mercury became known as the Torr after Torricelli.

Now there are; Inches of mercury, feet of water, pounds per square inch, and Pascals, to name a few.

Internationally today the preferred unit is the Kilo-Pascal. (kPa). ${ }^{11}$

In medicine units such as centimetres of water and millimetres of mercury remain commonplace due largely to what is euphemistically called the "conservative" nature of the profession. Also they can be easily demonstrated without a pressure gauge.

When I first questioned that we could be using very high levels of suction for endotracheal suctioning at $550 \mathrm{~mm} \mathrm{Hg}$. I was assured that everything was fine since the pressure was only 75. Of course it was $75 \mathrm{kPa}$.

For the purposed of this paper the following conversion is used; ${ }^{14}$

$1 \mathrm{mmHg}=1.36 \mathrm{cmH} 2 \mathrm{O}=0.133 \mathrm{kPa}=0.0193$ PSI

A Pascal (Pa) is a Newton-per-meter squared. 


\section{Pressure}

Variations in air pressure are important in the life of the whole planet and the life upon it.

At sea level the atmosphere exerts a pressure of one kilogram over every centimetre of surface area or about 101.8 kilo Pascals. $(\mathrm{kPa})$. This pressure decreases as we gain altitude until the earth is left behind and we find ourselves in the 'vacuum' of outer space. At 10,000 feet the air pressure is about $70 \mathrm{kPa}$ or negative $30 \mathrm{kPa}$ of gauge pressure. ${ }^{11,13}$

Back at ground level the wind and weather is generated by high and low pressure cells circling the earth between the range of $8.70 \mathrm{kPa}$ and $10.94 \mathrm{kPa}$. The power of the atmosphere pressure at ground level is not inconsiderable.

Within this $224 \mathrm{hPa}(2.24 \mathrm{kPa}$ or $16 \mathrm{~mm} \mathrm{Hg}$.) range are the triggers of the strongest winds and hurricanes and the source of wind energy production. A fall of only $1.30 \mathrm{kPa}$ barometric pressure can trigger destructive storms. At sea level a cubic metre of air weighs about $1.2 \mathrm{Kg}$ depending on the temperature and a litre of air about 1.2 grams. Which will allow a Boeing 747 laden with passengers and luggage to float into the air and, as long airflow over the wings, can create a slightly more negative pressure above than below the wing, remain in the air happily up to altitudes of 35.000 or more feet where air pressure is only a fifth of what it is at sea level. It is the flow times the mass that equals the amount of work a breeze may perform.

In the hospital setting a mechanical vacuum generator might produce a negative pressure of up to minus $80 \mathrm{kPa}$, , routinely in the medical setting, we aim to supply this pressure at the piped vacuum supply outlet. This is of course $101 \mathrm{kPa}$ minus 80 . And roughly the atmospheric pressure at 25,000 feet which is $38 \mathrm{kPa}$ or $0.384 \mathrm{Kg}$ per square centimetre. 25.000 feet is about as high as a human being can survive without supplemental oxygen although at anything over 10,000 feet a significant risk of high altitude pulmonary oedema is present.

In large medical facilities vacuum is developed by large centrally located vacuum pumps and piped to wall outlets where it may be regulated as clinically indicated for a variety of uses from surgical scavenging in the open wound to gentle wound suction and aspiration. 
The Australian Standard AS $2120.31992^{15}$, (Medical suction equipment. Suction equipment powered from a vacuum or pressure source), sets out minimum requirements for suction systems but is not concerned with the clinical application of suction. ISO 10079-3:1999 is the international equivalent. In Britain; BS EN ISO 10079-3:2000, In the USA; NFPA 99 5.1.12.3.10.4.

Internationally the piped medical suction is presented at the wall as a primrose yellow colour outlet. Oxygen being white and the air outlet coloured black. There will be a panel within the vicinity displaying the current pressures within the system. ${ }^{16,17}$

A device needs to be attached to the suction outlet to allow access. This might range from a simple on/off valve to a complex regulator device.

The simple on/off tap will allow the flow to be adjusted but not the ultimate occlusion pressure so that only the time to maximum vacuum will be reduced ${ }^{18}$.

The on/off tap is sometimes supplied with a pressure gauge but this may be better thought of as a suction gauge as it will measure the increase suction as a function of the airflow through the system. The gauge pressure will still equal that presented at the wall when the system is occluded or the tap fully open.

A vacuum regulator on the other hand will set a maximum occlusion pressure as well as adjusting the flow of air the system or suction force. ${ }^{16}$ Usually an occluded pressure setting will be made prior to the commencement suctioning as described by the manufacturers specifications.

It is the difference between an area of high and low pressure or density of a gas or fluid that will induce the flow we perceive as suction. This is the field of fluid dynamics. The reduction in pressure created by the machinery of the central piped suction plant will create airflow at the unguarded wall connection of some 80 plus litres per minute as the air in the room rushes to fill the void created by the negative vacuum. A hose connected to this outlet will direct this airflow to sweep particles into the hose and collection jar if one is placed in the hose line. 
The difference between this negative pressure and the atmospheric pressure creates the airflow which in turn produces work energy. In the hospital we use this for the suction that will clear an airway of vomitus, an open wound of blood, to maintain a clear operating field, to remove tracheo bronchial secretions and gently remove exudates from healing wounds.

Venturi suction is generated by harnessing the Bernoulli Effect from a high flow compressed gas source and remains a valuable source of portable suction ${ }^{16-18}$. The venturi vacuum effect is harnessed in devices such as paint and garden spray guns, perfume atomisers and sand blasters for cleaning. While mostly seen in portable devices many hospitals still rely on a venturi device to generate their piped suction. Later we will consider the venturi effect large air flows may have on lung volume during endotracheal suctioning.

While a simple scavenging apparatus has saved many lives in the medical setting. There are, however, times when this negative pressure is directed to closed spaces such as the stomach a closed wound drain or the trachea and bronchial tree. Then it may be vital to reduce this suction force so as to reduce the negative pressure effects within the body cavity.

Just as it is possible to vacuum the house without creating a negative atmospheric pressure within, it will be desirable to apply just enough suction to remove the debris as desired without causing physical damage to the surrounding furnishings. This will require fitting a suction regulator to the wall outlet to control the amount of negative pressure and subsequent force of airflow at the hose or catheter end. Otherwise, as we have described, the sudden application of suction would be akin to opening the aircraft window at 25,000 feet.

Without regulation the air pressure within the body cavity can quickly reduce to that presented by the wall outlet minus air flow that can be entrained from without that cavity.

This brings us to the question of endotracheal tube suction or aspiration of secretions through the endotracheal tube of an intubated patient as part of their routine and therapeutic regime. 
It has been common practice in some parts of Australia to connect the endotracheal suction directly to the wall suction outlet via a couple of tubes and a collection bottle leaving the ultimate occlusion pressure of the system at that presented at the wall outlet with perhaps only a simple on / off tap.

This assumes that the flow will be limited by the narrowness of the tubing and increasing resistance from its length and while to some extent this is true in that the time to maximum occlusion pressure is reduced it is not to the extent we may have assumed. Possibly this is because more modern piped vacuum produced by powerful mechanical pumps has crept up on clinicians more used to older venturi systems. Earlier systems aimed to present an occlusion pressure of at least $400 \mathrm{~mm} \mathrm{Hg}$ at the wall outlet and a flow of greater than 40 litres per minute. Over time it is possible that contamination and soiling may obstruct the piped system, even though filters are integral, and the flow rate become diminished. Nevertheless maintenance should ensure that the minimum standard is retained.

While the vacuum delivered to the wall outlet may vary depending on the hospital wide demand it remains generally within a range of 70 to $80 \mathrm{kPa}$ with a flow rate to the outlet of some $80 \mathrm{~L} / \mathrm{min}$. in line with the Australian Standard.

Unregulated, the flow through the size $14 \mathrm{Fr}(4.7 \mathrm{~mm})$ suction catheters remains around 54 $\mathrm{L} / \mathrm{min}$. The flow through the size $12 \mathrm{Fr}(4 \mathrm{~mm})$ suction catheters is about $40 \mathrm{~L} / \mathrm{min}$. These results based on some personal research and observations. Full details are available from the author on request. ${ }^{19}$

And the effect when these are passed through an endotracheal tube into the trachea is to create a negative pressure within the lung of at least $4 \mathrm{~mm} \mathrm{Hg} .8 \mathrm{~mm} \mathrm{Hg}$ if a size $14 \mathrm{Fr}$ catheter is used with a size 8 ID et tube and can be $22 \mathrm{~mm} \mathrm{Hg}$. (30 $\mathrm{cm} \mathrm{H} 20)$ if a size 14 catheter is passed through a size 7 ID tube. This negative intrapulmonary pressure only increases as the catheter is advanced beyond the end of the endotracheal tube into a bronchus or bronchiole.

Ultimately the laws of physics require that a measured amount of vacuum and flow be imposed upon the pulmonary system during endotracheal suctioning. ${ }^{20-22}$ Some forty years ago Rosen and Hillard ${ }^{23}$ described the potential for dangerously high levels of vacuum to 
be developed during suctioning and made a recommendation that the suction catheter should occlude less than half the internal lumen of the endotracheal tube. Vanner and Bick writing in Anaesthesia ${ }^{24}$ described flow rates and negative pressures that may be developed using various size catheters and an occlusion pressure of $500 \mathrm{mmHg}(76 \mathrm{kPa})$. Through the anaesthetic machine they used flow rates may be reduced though not the ultimate 'occlusion' pressure. This would put their figures more in the range we have measured with a suction occlusion pressure of $300 \mathrm{~mm} \mathrm{Hg}$. using a similar bench top arrangement and the High vacuum suction regulator. In personal correspondence Dr Richard Vanner has pointed out that a shorter ET tube will reduce the subsequent negative pressure at the end. However this will increase the depth that a catheter may be inserted into the lung inadvertently if as we read in many guides, the catheter is inserted until resistance is met then withdrawn $2 \mathrm{~cm}$, very high levels of negative pressure may be imposed upon the lung structure.

Flow rates through suction catheters have been examined in a paper Campos 2005 presented at the eighteenth international congress of mechanical engineering ${ }^{20}$, describing flow rates and developed suction pressure with an occlusion pressure of $120 \mathrm{~mm} \mathrm{Hg}$. $(16 \mathrm{kPa})$.

A simple demonstration on the power of a suction device can be performed by taking a 2 litre plastic bottle and "intubating" it by placing an $8 \mathrm{~mm}$ internal diameter ET tube or alternatively a $30 \mathrm{~cm}$ piece of $8 \mathrm{~mm}$ plastic tubing in the top. Holes should be made in the bottom of the bottle and then standing it in a basin of water so that the water level in the bottle and basin equalise. This model can be suctioned using an open suction technique. As a suction catheter is inserted into the bottle through the $8 \mathrm{~mm}$ Endotracheal tube and suction applied, the pressure in the bottle will decrease relative to the atmospheric pressure pushing down on the water in the basin and the water level in the bottle will rise. As the vacuum is increased by turning the dial on the suction regulator or the tap on the wall suction outlet the water level will rise. The amount of suction force will be directly affected by the airflow through the system. The speed of the air flow will ultimately be limited by the power of the vacuum applied and the resistance offered by the suction catheter ET tube combination. The subsequent vacuum within the bottle will be seen as the level of water in $\mathrm{cm}$. 


\section{The Branching Nature of the Human Airway}

From an anatomical review of the lung we can see that the lungs far from being a, "bag in a box", as often depicted in those old textbooks, are a branching structure as is commonly found in nature (refer to figure 1). The sort of structure described by Mitchell Feigenbaum in his theory of order and chaos as is replicated in nature. ${ }^{25}$ But also the structure you can easily make out when driving through the countryside in winter.

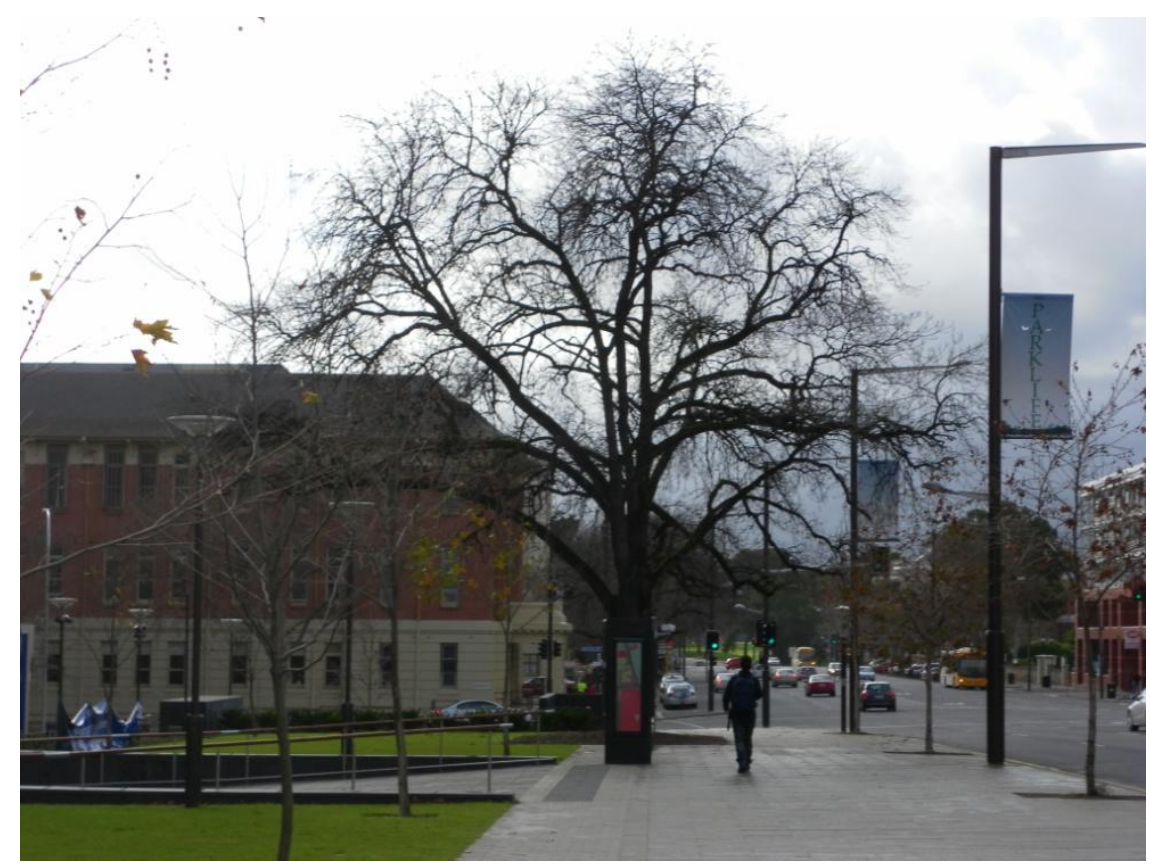

Figure 1: Branching in Nature (Photo by Author)

The dark bare branches of the trees giving a stark pictograph of a branching model, looking verisimilar to the airways of the lung with the alveolar leaves stripped away. ${ }^{26}$

Similar images have been produced my modern spiral CT scans of human airways and their complex branching structure can now be mapped and measured to an accuracy never before seen. ${ }^{27}$ 


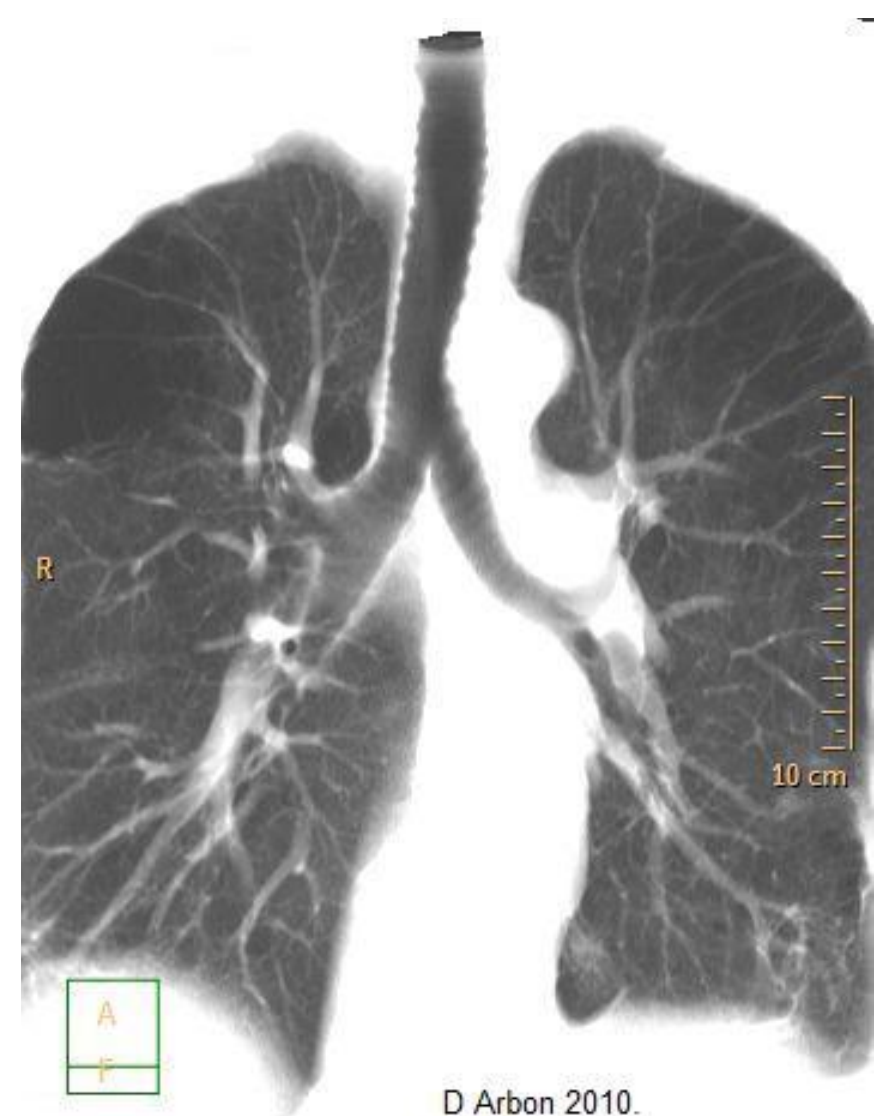

Figure 2: CT Scan of the human airways (Photo by Author)

Now we can see the nature of the lung, a collection of ever diminishing tubular segments and although a single breath might be dispersed throughout these passageways with practically no resistance. It is however, easy to see that individual branches when occluded by disease or mechanical invasion will starve the segments beyond of air.

How quickly the airway narrows is of crucial importance to our investigation of endotracheal suctioning for the distance the catheter is inserted and the width of the catheter will dictate how quickly an airway may be occluded ${ }^{28}$. 


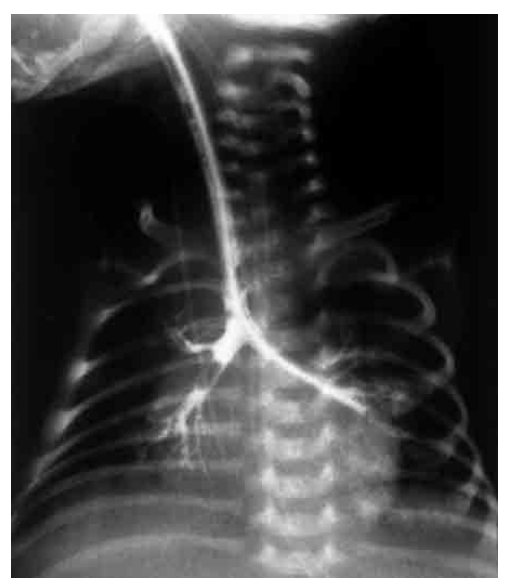

Figure 3: Neonatal Airway (Author)

A bronchoscopic voyage down the airways will also reveal this branching and narrowing of the human airways. ${ }^{27}$

The adult Trachea is usually about $120 \mathrm{~mm}$ long and $18 \mathrm{~mm}$ in diameter. This divides into the right and left primary bronchi $12 \mathrm{~mm}$ by $47 \mathrm{~mm}$ with the right being a little shorter and wider than the left.

The lobar bronchi are about $8.3 \mathrm{~mm}$ by $19 \mathrm{~mm}$ finding us $178 \mathrm{~mm}$ into the lung.

The next level or segmental bronchi are $5.6 \mathrm{~mm}$ in diameter and $7.6 \mathrm{~mm}$ long and branch again into smaller bronchi at levels 5 to 10 with diameters shrinking from $3.5 \mathrm{~mm}$ to $1.3 \mathrm{~mm}$ in diameter and lengths from 10.7 to $4.6 \mathrm{~mm}$.

Finally we come to level of 11 to 13 with diameters of 1.09 to $0.8 \mathrm{~mm}$ and lengths of 3.9 to $2.7 \mathrm{~mm}$.

Now we have travelled about $260 \mathrm{~mm}$ into the respiratory tree.

When a guideline says to the caregiver, "Insert the suction catheter until resistance is felt, then withdraw $2 \mathrm{~cm}$ and commence suctioning", an assumption is commonly made that the catheter will come into contact with the carina at the first bifurcation then resistance will be felt. However, seeing the catheter inserted to the hilt, then plainly this is not so. 
If an endotracheal tube is inserted such that its outlet is $2 \mathrm{~cm}$ above the Carina, a $50 \mathrm{~cm}$ suction catheter inserted "until resistance is felt" may extend $20 \mathrm{~cm}$ beyond the opening of the ET tube into the narrowest of bronchi. The $50 \mathrm{~cm}(500 \mathrm{~mm})$ suction catheter can easily reach $20 \mathrm{~cm}(200 \mathrm{~mm})$ beyond the end of the ET tube exploring blindly passages even a $5 \mathrm{~mm}$ diameter Bronchoscope cannot visit.

The segment of lung to be suctioned and in all probability collapsed is unknown.

Research has unsurprisingly then found that suctioning to a premeasured distance not more than $2 \mathrm{~cm}$ beyond the end of the ET tube to be less uncomfortable and have less adverse effects on the patient. ${ }^{29,30}$

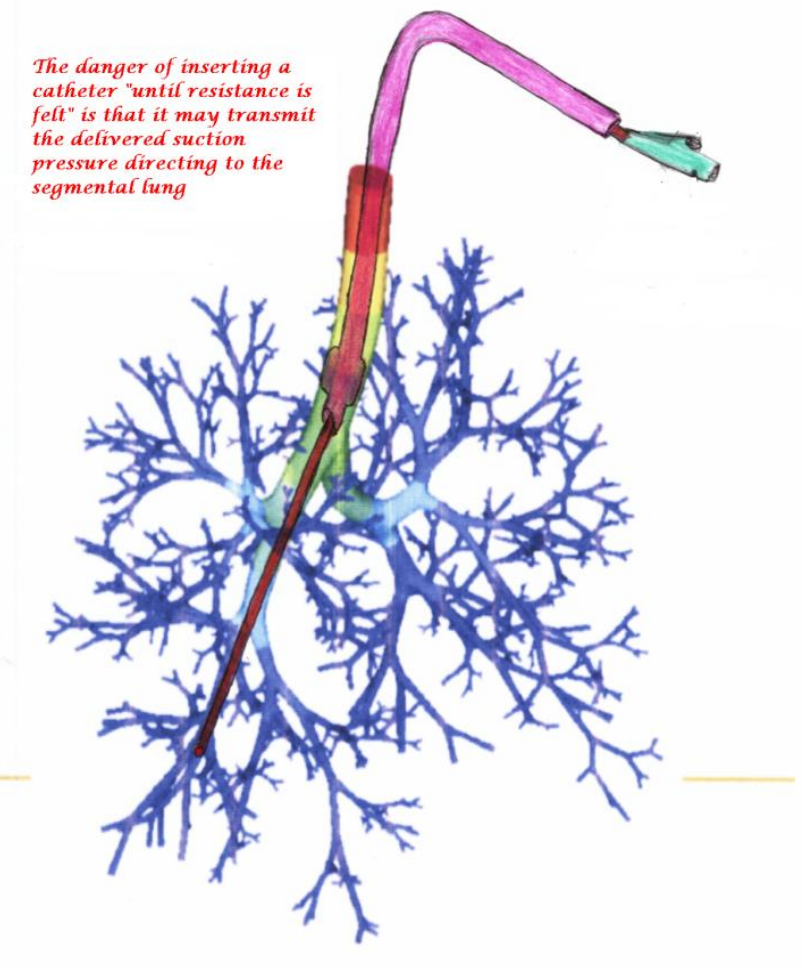

D. Arbon2011

Figure 4: Highlighting the narrowing of airways (illustration by author) 
The instant that suctioning is commenced the area beyond the suction catheter is exposed to a vacuum equivalent to that set on the suction regulator. From physics we know that the flow that results will depend on the diameter and length of the suction tubing.

From bench top measurements we know that a flow of some 40 Litres a minute can be achieved by a size 12 French scale suction catheter attached to the wall piped suction outlet and a flow of around 56 Litres per minute through the size 14 French suction catheter, towards the occlusion pressure of around $76 \mathrm{kPa}$. This flow is not diminished as the catheter is inserted further into the lung but the subsequent negative pressure distal to the catheter will increase significantly.

Regulating the vacuum occlusion pressure to around $14 \mathrm{kPa}(100 \mathrm{~mm} \mathrm{Hg}$.) will reduce the driving pressure and the resultant flow. Now the flow through our size 12 Fr suction catheter will be perhaps 15 Litres a minute ${ }^{24}$. This still represents 15 grams of mass and subsequent power to drag secretions through the tube. The reduced pressure of $14 \mathrm{kPa}$ is nearer to the maximum that the average adult can achieve against a closed airway by use of the respiratory muscles alone, although, even at this reduced pressure the symptoms of negative pressure pulmonary oedema are reported ${ }^{31-33}$. 


\section{Chapter 2. Systematic Review Protocol}

\section{Review Objective}

The principle objective of this review has been to critically appraise and present the best available evidence for setting different levels of vacuum / suction pressures when patients are receiving endotracheal suctioning.

Specifically the review has sought answer the following questions.

What is the best evidence for regulating vacuum pressure in the performance of endotracheal suctioning?

What is the best evidence for regulating vacuum pressure for endotracheal suction as opposed to setting no regulated pressure in the performance of endotracheal suctioning?

What is the best evidence for a limit to which vacuum should be regulated for endotracheal suction?

To what extent does the developed airflow impact on the safety and effectiveness of the suction apparatus?

\section{Background}

Endo-tracheal suctioning, an essential component in the management of airway patency and secretion removal in the critically ill, has become a routine part of care for mechanically ventilated patients in the Intensive Care Unit. ${ }^{1,2}$

The artificial airway mechanically disrupts the muco-cilliary escalator resulting in a pooling of secretions below the endotracheal tube that will need to be removed by the suction catheter ${ }^{1,2}$. Furthermore the Endotracheal (ET) tube itself is inclined to become occluded with bio-films after a short period insitu ${ }^{2}$, making it necessary to perform this 
suctioning of the airway to keep the airway patent and remove respiratory secretions as part of the care of the intubated patient.

- Various risks are involved in the procedure since the earliest days of invasive respiratory support including "death by suctioning". ${ }^{3}$ These risks include;

- Atelectasis; Reported and shown by radiological exam as early as the 1940 's ${ }^{3-5}$

- Pulmonary haemorrhage has been seen with rapid decompression of segmental lung, with mechanical trauma from catheter impaction or sudden explosive decompression. $^{6-8}$

- Tissue trauma has been reported from the vigorous insertion of the suction catheter or impaction as the tissue lining the airway is suctioned into the side ports of the catheter. $^{6,9,10}$

- Negative pressure pulmonary oedema may be a result of the negative intrapulmonary pressure across the alveolar capillary bed. Negative pressure pulmonary oedema is sequel to sudden reduction suction in air pressure at the alveolar level. This is more often seen in cases of laryngeal-spasm after surgery. ${ }^{33-}$ 36

In Australia medical suction from a piped source should comply with Australian Standard AS 2120.3 1992. ${ }^{15}$ The United States Standard is similar, NFPA 99 5.1.12.3.10.4.

The unguarded outlet in a modern hospital piped vacuum system may have an occlusion pressure of around $80 \mathrm{kPa}(600 \mathrm{~mm} \mathrm{Hg}$.) below atmospheric pressure and develop a flow though the outlet of over 80 Litres a minute. ${ }^{17}$ This vacuum may then be used directly to clear a large amount of blood or vomitus from an operation site or oropharynx or regulated to an appropriate level for thoracic suction or removal of exudates from a healing wound.

An examination of current evidence based research reveals a recommendation that a regulated suction pressure of $80 \mathrm{~mm} \mathrm{Hg}$ to $150 \mathrm{~mm} \mathrm{Hg}$ (11 to $20 \mathrm{kPa}$ ) be set prior to performing endotracheal suctioning in the Adult patient suggesting this may be increased to $200 \mathrm{~mm} \mathrm{Hg}(26 \mathrm{kPa})$ if secretions prove difficult to clear. ${ }^{1,2,37}$ 
Even so, in many intensive care units this suction is taken directly from the wall mounted high pressure suction outlet and the hospital piped vacuum system, a simple on / off tap being fitted which may deliver a vacuum level which has been described as being between effective and unsafe. ${ }^{38-40}$

From this we see a very large difference between theory and practice in some institutions and an invitation for further investigation.

A search of the references quoted in these systematic reviews and meta analysis of the endotracheal suctioning proceedure ${ }^{1,2,37}$, leads back to the work of Rosen and Hillard in the 1960s and their investigation into the physical properties of hospital suction systems and their application to patient care. . $^{32}$

This research was among the first to recommend using a suction catheter that occluded less than half the internal diameter of the endotracheal tube in order to prevent the build up of large negative intra-pulmonary pressures during the suctioning procedure as there would be sufficient return airflow down the endotracheal tube to compensate for that removed by the suction catheter within the lung.

Choosing a size of suction catheter is complicated by the common misunderstanding of Charriere's French scale commonly used for labelling suction catheters. While converting the French scale to $\mathrm{mm}$ merely involves dividing the number by 3 , many persist in complicating the issue by using inaccurate mnemonics and calculations such as times the ET size by two and minus two which of course gives 14fr. for a size 8 ID (internal diameter) tube. This issue is further complicated by considering that it may be better to think about the area of the lumen taken up by the area of the circle created by the suction catheter ${ }^{2}$.

Another aspect of this issue to come out of the seminal work of Drs. Hillard and Rosen is the fact that it is the air flow generated by a vacuum through a tube that actually is responsible for pushing the secretions into the suction catheter and creating the negative pressure in the pulmonary space. ${ }^{3,24}$ A cubic metre of air may weigh 1.2 kilograms at sea level and every litre 1.2grams. The weight of air moved by the more powerful vacuum will 
produce more work energy and a stronger suction force. As shown more recently in the work of Vanner, little intra pulmonary pressure drop with is seen with air flow rates up to 25 Litres / min., when the suction catheter occludes less than half the internal diameter of the endotracheal tube ${ }^{24}$. However in unpublished research, with assistance of the Biomechanical Engineering section of Flinders Medical Centre, in South Australia we have been able to measure some negative pressures developed in vitro using suction taken directly from the piped suction outlet. The research discovered that using the normal suction arrangement and a model similar to that used by Vanner, though minus the Anaesthetic machine, significant flows and subsequent negative pressures developed. A flow rate of some 56 litres / min was achieved through a size 14Fr catheter and 40 Litres / min through the size $12 \mathrm{Fr}$ catheter toward the occlusion pressure of $550 \mathrm{~mm} \mathrm{Hg}$. These large flow rates may impose significant forces upon the small airways the results of which should be clarified by this review.

When inserted through a size 8 Internal Diameter endotracheal tubes a negative pressure of over $8 \mathrm{~mm} \mathrm{Hg}$ is created using a size $14(4.7 \mathrm{~mm})$ catheter and negative $4 \mathrm{~mm} \mathrm{Hg}$ when a size $12(4 \mathrm{~mm})$ suction catheter is used. Similar results were documented by Dr. Rosen in $1960^{3}$.

This increase is negative pressure as the ET tube narrows in relation to the suction catheter is an expression of the Bernoulli principle as the catheter within the endotracheal tube forms an annulus and resultant negative pressures may be calculated in compliance with the Hagen-Poiseuille Law ${ }^{41,42}$.

As the suction catheter is advanced further into the bronchi, current practice being to advance the catheter until resistance is felt and withdraw $2 \mathrm{~cm}$ before commencing to suction, the $50 \mathrm{~cm}$ suction catheter tip may be found within a narrow branch of the bronchial tree some $18 \mathrm{~cm}$ beyond the end of the ET tube ${ }^{42}$. Advances in medical imaging make visible the rate at which the airways of the bronchial tree narrow so that an examination of these studies may help to clarify the issue of intrapulmonary vacuum pressure. $^{26,27,43}$ it is a physical certainty that subsequent negative pressure within that area of lung will increase since as the further the catheter is inserted into a narrowing tube the higher resistance will create a higher level of negative pressure distally. A review of 
radiological findings in children before and after the implementation of regulated suction in a paediatric intensive care unit shows a significant statistical reduction in the incidence of right upper lobe collapse. ${ }^{5}$ Further studies have shown a reduction in adverse events when the catheter was advanced no more than $2 \mathrm{~cm}$ beyond the endotracheal tube ${ }^{44}$.

Recent studies concerning the effects of endotracheal suction have been conducted in animal subjects. Research conducted by Hogmann in Sweden has noted the risks of lung injury at suction pressures of $14 \mathrm{kPa}(120 \mathrm{~mm} \mathrm{Hg}),{ }^{45}$. These findings appear in the published work of Almgren and colleagues ${ }^{9,39}$. Further animal and human studies have demonstrated airway collapse during suctioning using computed tomographic scans ${ }^{46,47}$.

It has been postulated that any loss of alveoli from sub-atmospheric pressure developing during suctioning may be detrimental and closed suction systems, whereby the patient may be suctioned without disconnection from the ventilator, has been promoted as a means of maintaining Positive End Expiration Pressure (PEEP) and hence lung volume during this procedure. The modern microprocessor controlled ventilator can deliver airflow to compensate for the flow being extracted by the suction catheter, maintaining lung volume.

While traditionally a manual hyper-inflating series of breaths delivered by hand ventilator has been the method of choice for recruiting lung segments lost to atelectasis during suctioning, in recent times the concept of the 'open lung' has been developed discouraging disconnection from the ventilator and suggesting that even the loss of PEEP as the pressure within the lung returns to atmospheric on disconnection is to be avoided ${ }^{48}$.

The question then is how to perform this essential procedure without creating unwanted negative intrapulmonary pressure?

In this review an examination research studies as well as expert opinion has been combined with a search for literature examining the effects of suctioning on airway compliance and lung function as well as the findings and reports of expert clinicians working in the field to synthesize a recommendation with regard to setting of a safe vacuum level for performing endotracheal suctioning. 
Prior to the commencement of this systematic review, the Cochrane Library, CINAHL and Joanna Briggs Institute (JBI) Library of systematic reviews were searched to ensure that no previous systematic reviews on this specific subject were identified or in progress.

\section{Inclusion Criteria}

\section{Types of Participants}

Patients receiving mechanical ventilator support through endotracheal tube or tracheostomy in the acute care setting.

Participants may present with a variety of pathologies but studies will not be excluded on the bases of diagnosis.

Patients may require intubation and endotracheal suctioning at any age; vacuum applied in the performance of suction may have health implications and be of interest to the clinician.

Papers regarding either spontaneously breathing and/or machine ventilated subjects have been also included so long as the participants required endotracheal suctioning in the acute stage of their hospitalisation.

\section{Types of intervention / Phenomena of interest}

The setting of a level of vacuum / suction pressure, taking into account the developed flow, to facilitate safe endotracheal suctioning in the acute care setting of the Intensive Care unit, High Dependency or Emergency Area.

\section{Types of outcomes}

Outcomes related to mortality, morbidity, and health benefits of regulating suction / vacuum pressure as opposed to having no regulation, i.e. using the unguarded wall outlet, have been sought. 
The effects of negative pressure within the tracheo-bronchial tree including

- Atelectasis;

- Pulmonary haemorrhage;

- Tissue trauma

- $\quad$ Negative pressure pulmonary oedema

\section{Types of studies}

In keeping with the demands of a Systematic Review all quantitative studies in the human population that relate to the objectives of the review have been considered for inclusion.

This review has considered any randomised-controlled trials that address the issue of suctioning artificial airways, specifically with regard to the effects of setting a suction or vacuum level.

In the absence of randomised controlled trials specific to our question, other research designs have been assessed for inclusion using the following hierarchy as it is applied for systematic review:

- Randomised Controlled Trials examining other aspects of this procedure have been considered for data extraction.

- Quasi-randomised control trials

- Quasi - experimental studies

- Cohort studies

- Cases controlled studies

- Case series 
- Case reports

- Expert opinion.

\section{Search Strategy}

The search strategy has aimed to find both published and unpublished studies in English. An initial limited search using SCOPUS was undertaken. An analysis of the text words contained in the title and abstract and of the index terms has then been undertaken in CINAHL, PUBMED and SCOPUS. Thirdly, the reference list of all identified reports and articles has been searched for additional studies.

The search included when possible the earliest reports from the1940s, and the earliest days of mechanical ventilation, as these continue to inform practice, and up until the present.

Published and unpublished hospital guidelines / procedure manuals have been searched for references in regard to vacuum pressure setting.

A search of grey literature including papers from Australian, North American and European critical care professional organisations has been made. Experts from the field were contacted for advice regarding local practice and reference materials.

A search of reference lists and bibliographies for original sources was carried out manually.

Search terms:

- Endotracheal suction

- Tracheal toilet

- Tracheal suction

- Regulating Tracheal suction Pressure.

- Hospital suction systems 
- Suction Pressure

- Vacuum

- Atelectasis

- Collapse

- Trauma complications

- Negative pressure pulmonary oedema.

\section{Assessment of methodological quality}

Papers selected were initially assessed by two independent reviewers for assessment of methodological quality using standardised tools from Joanna Briggs Institute Meta Analysis of Statistics and Review Instrument (Appendix II). Any disagreements arising between the reviewers, resolved through discussion with a third reviewer. A secondary reviewer and fellow JBI Masters student, Dora Lang Siew Ping, performed the secondary critical appraisal for all papers. As this systematic review contributes to the award of a MSc Clinical Science, a secondary reviewer has only been employed for the processes of critical appraisal and data extraction.

\section{Data extraction}

Quantitative data were extracted where possible from papers included in the review using the standardised data extraction tool from JBI-MASTARI. The data extracted includes specific details about the interventions, population, study methods and outcomes of significance to the review question and specific objectives using a data extraction tool (Appendix III).The primary review extracted data from all included papers and the secondary reviewer and fellow JBI Masters student, Dora Lang Siew Ping, performed a check of the accuracy of extracted data. As this systematic review contributes to the award of a MSc Clinical Science, a secondary reviewer has only been employed for the processes of critical appraisal and data extraction. 


\section{Data Synthesis}

Where possible, quantitative research study results were to be pooled in a statistical metaanalysis using the Joanna Briggs Institute Meta Analysis of Statistics Assessment and Review instrument (JBI-MAStARI). All results subjected to double data entry. Odds ratio (for categorical data) and weighted mean differences (for continuous data) and their 95\% confidence intervals calculated for analysis. Heterogeneity assessed using the standard chisquare. However since statistical pooling has not been possible the findings have been presented in narrative form.

\section{Conflicts of Interest}

None known. 


\section{Chapter 3. Review Results}

\section{Description of studies}

The literature search was conducted as described in the protocol with additional research being retrieved from an examination of the references to setting a level of suction for endotracheal suctioning contained within the various clinical guidelines, expert opinion papers and meta-analyses. (Appendix VII)

Search initially identified 5,537 potentially relevant papers.

Based on inclusion criteria we decided to retrieve only 183 abstracts for further examination.

After examination of abstracts 135 papers were excluded. The reasons for exclusion of these papers were: these papers were not primary research papers but literature reviews, systematic reviews with or without meta analysis, or clinical practice guidelines. We decided to examine the full text paper of 48 studies out of 183 retrieved.

After examination of the full text paper 18 papers were excluded. The list of all excluded 18 papers is presented in appendix VI.

30 full text papers were examined for methodological quality. No studies were excluded on the basis of methodological quality alone. 30 papers were then included in the review. Details of included studies are included in appendix V. 


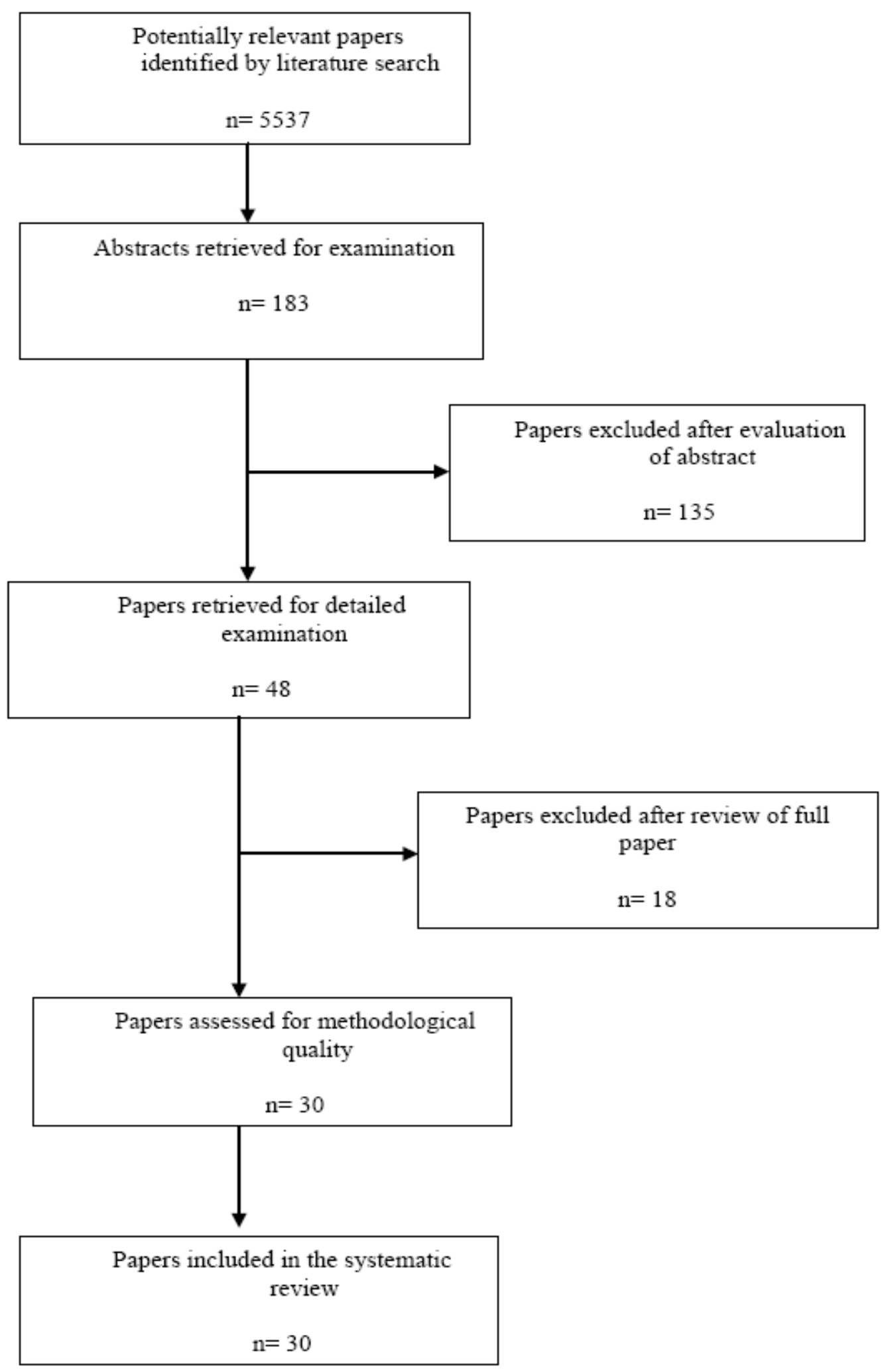

\section{Figure 5. Flowchart for studies selection}




\section{Methodological Quality}

Of the 30 included human studies examined none were excluded on the grounds of methodological quality alone. The 30 included studies though often involving small sample size did however represent careful quasi experimental or observational designs reporting outcomes of interest to this review. Although of a heterogeneous nature with regard to experimental and reporting methods a consistent causal inference of the effects of suction / vacuum pressures with regard to endotracheal suctioning could be extracted as a narrative summary.

\section{Results}

The earliest studies of the phenomena of endotracheal suction and the effects on tracheobronchial trauma date back to the 1950's and the work of Plum and Dunning ${ }^{49}$ progressing through the 1960s with Rosen and Hillard' ${ }^{23}$ discussion of optimal suction / endotracheal tube diameters to reduce the risk of large negative pressures developing in the lung during suctioning ${ }^{50,51}$. In the 1970s the potential for suction catheter induced tracheobronchial trauma was further investigated ${ }^{52}$ Even in the twenty first century Kuzenski's study of the effect of suction trauma in two mongrel dogs is often cited ${ }^{53}$. By the 1990s consensus with regard to setting an optimal level of suction vacuum pressure for endotracheal suction appears to have been arrived at ${ }^{54,55}$ and the focus turned to evaluating the proposed benefits of "open vs. closed" endotracheal suctioning ${ }^{56}$. Now the pressure set on the suction regulator became an almost standard parameter while levels of lung volume loss or haemodynamic instability are examined in human and animal studies with different ventilator modes during open or closed endotracheal suctioning. 
Today, while the debate regarding open and closed suctioning continues, "Open Lung" theory ${ }^{48}$ and the interest in reducing the incidence of as well as optimising the treatment of Acute Lung Injury has turned the spotlight on the need to minimize shearing forces at alveolar level whilst maintaining effective ventilation. ${ }^{4,56,57}$

From included studies we extracted findings related to our outcomes of interest.

- Tissue trauma/Pulmonary haemorrhage

- Atelectasis, Loss of Volume, Segmental Collapse.

- The Haemodynamic effect of negative intra plural pressure.

- Benefits of Regulating vacuum exposure versus no regulation / free flow.

\section{Tissue trauma/pulmonary haemorrhage}

As described earlier, Plum and Dunning ${ }^{49}$ in 1956 developed a method of regulating endotracheal suctioning in an effort to reduce tracheal trauma and since then advances have been made with regard to the design and fabrication of suction catheters to make them as atraumatic as possible. Interestingly no further human research was uncovered with regard to suction induced trauma, follow up research being exclusively conducted in the animal model. Perhaps due to her ability to pool together the previous studies with regard to suction induced trauma concisely, Kuzenski ${ }^{53}$ remains a cited reference with regard to the reporting of suction induced trauma to the airways.

\section{Atelectasis, Loss of Volume, Segmental Collapse}

13 papers were retrieved with outcomes of particular interest regarding loss of lung volume through endotracheal suctioning. While it was generally conceded that having the suction catheter take up less than half the internal lumen of the endotracheal tube this was not consistently applied in the research and the conversion of French gauge to millimetres of diameter as we have alluded to in the background, frequently confused. 
Over time it has become accepted that even at the usually recommended level of vacuum pressure a degree of collapse will be found usually with loss of positive end expiratory pressure with disconnection from the ventilator but also as more air is extracted from the lung than may be entrained through the endotracheal tube. The suction catheter creating an annular flow which will increase the negative pressure within the lung segment as the catheter is inserted deeper into the lung.

A 1969 study by Brandstater ${ }^{50}$ of lung volume loss in very young ventilated children with tetanus, using a suction / vacuum pressure of not more than $33 \mathrm{mmHg}$, discussed the possibility of applying increased inflation pressure in an effort to restore lung volume loss of reportedly around $50 \%$ as part of a recruitment manoeuvre.

In 1963, Egbert, L.D., Laver, M.B. and Bendixen H.H ${ }^{58}$, noted that loss of compliance was observed whenever deep breaths were not part of the respiratory cycle and this was seen in patients and in animal studies during constant volume ventilation. Also higher pressures are needed to reopen collapsed airspace. In a study of 36 patients during anaesthesia they observed that passive hyperinflations during anaesthesia had advantages in maintaining compliance. A fall in compliance or lung volume fall was seen after endotracheal suctioning which could be restored by assisted breaths at positive pressures of around $20 \mathrm{~cm} \mathrm{H} 2 \mathrm{O}$. The authors note that in 1963 a reliable method of measuring atelectasis from suctioning does not exist.

In a combination of animal and human study by Fell, T. \& Cheney, F.W. $1972^{59} 26$ adult patients were observed during a suctioning regime with a reported negative pressure of 60 mm Hg. developing a flow of 18 litres / minute through a suction catheter. Subjects were intubated with $8 \mathrm{~mm}$ internal diameter endotracheal tubes. This study found that the most effective way to prevent hypoxia was to hyper-oxygenate the patient for one minute prior to suctioning and limit the suction to 15 second. Of interest to our practice also is the observation that coughing or "bucking" associated with endotracheal suction serves only to increase de-oxygenation. Often it is thought that the cough elicited by the insertion of the suction catheter serves to push secretions within reach of the catheter for easier removal however this is not borne out by the research. 
In 1996 Boothroyd, A.E $E^{5}$ surmised that the frequent right lower lobe collapse observed in the cardiac surgery area of the children's hospital might be an effect of endotracheal suctioning with high levels of vacuum pressure in an unregulated fashion. Initiating a regime of careful endotracheal suction of a less invasive nature at a vacuum not exceeding $120 \mathrm{~mm} \mathrm{Hg}$ a significant decrease in the incidence of this adverse finding was observed.

Cereda, M., et al. ${ }^{60}$ in a 2001 study of ten patients in the intensive care unit of a university teaching hospital found that lung volume loss from suctioning could be reduced if closed suction systems were used allowing the ventilator to supply sufficient inflow to offset extraction at a vacuum level of $100 \mathrm{~mm} \mathrm{Hg}$.

A study has been conducted in an intensive care setting in New Zealand by Frengley, R.W., Closey, D.N., Sleigh, J.W. \& Torrance, J.M. $2001^{61}$ with a bench top component, using a reasonably high level of vacuum pressure; $370 \mathrm{~mm} \mathrm{Hg}$. They described the airway pressure developed with three different airway suctioning techniques noting that it was the difference between the amount of air extracted and the flow back into the lung from the ventilator or freely down the endotracheal tube that influenced the loss of lung volume.

In a study in which the level of suction was described as $400 \mathrm{~mm} \mathrm{Hg}$., Dyhr and Bonde $2003^{62}$, examined the effect of suctioning in 8 patients with an acute lung injury finding significant risk of drop in oxygenation and lung volume, suggesting that perhaps endotracheal suction should be avoided in these patients if at all possible. This adds weight to the argument that $300 \mathrm{~mm} \mathrm{Hg}$ may be as high a pressure as one might be advised to set on the suction regulator but not routinely. I have been able to repeat the interesting bench top experiment they performed demonstrating the increasing level of negative pressure through various catheter ET tube combinations. 
Maggiore, S. et al, $2003^{63}$ in a study of the effects of suctioning in 9 patients with Acute respiratory distress syndrome and acute lung injury it found that avoiding disconnection from the ventilator reduced the lung volume loss associated with endotracheal suctioning at

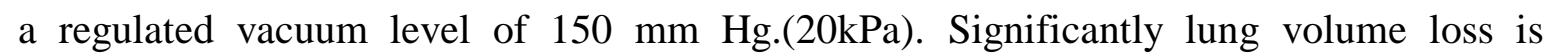
associated with disconnection of the ventilator alone during positive pressure ventilation and this effect may once again be offset by maintaining the pressurisation of the system during the suctioning event. This level of suction is consistent with current professional recommendations. ${ }^{2,10,64}$

In a study by Fernandez, M.-d.-M., Piacentini, E., Blanch, L. \& Fernandez, R. $2004^{65}$ looking at changes in lung volume with three systems of endotracheal suctioning with and without preoxygenation in patients with mild to moderate lung failure in 10 patients with mild to moderate lung failure it was found that using a suction vacuum level of $100 \mathrm{~mm} \mathrm{Hg}$ to $200 \mathrm{~mm} \mathrm{Hg}$. open suctioning produced a lung volume loss of some 1,280 $\mathrm{ml}$ as compared with less than $500 \mathrm{ml}$ in a closed suction system without disconnection from the ventilator. The significance of this is to show that under controlled suction limited to less than $200 \mathrm{~mm} \mathrm{Hg}$ lung volume loss is seen although restored after 10 minutes of subsequent ventilation.

Morrow, B., Futter, M. \& Argent, $2006^{66}$ in an Australian study of 65 neonates in intensive care reported that there was no improvement in airway resistance after endotracheal suctioning at $360 \mathrm{~mm} \mathrm{Hg}$ suction / vacuum pressure. We note that this is not usually considered a safe level of vacuum in the pediatric setting but has not been uncommon in some parts of the world.

In a 2008 study by Heinze, H., Sedemund-Adib, B., Herringlake, M., Gosch, U. \& Eichler ${ }^{67}$ of post operative cardiac surgery patients' functional residual capacity was seen to be lost in all cases despite a suction/ vacuum pressure regulated to $150 \mathrm{~mm} \mathrm{Hg}$. It is noted that the technique of inserting the catheter until resistance is felt may increase the likelihood of segmental atelectasis. 
Lindgren, S., et al. ${ }^{28}$ in a 2008 study describing how bronchoscopic suctioning may cause lung collapse in a lung model and clinical evaluation described also the risk of segmental collapse as the suction catheter; in this case a bronchoscope occluded the airway preventing a return flow to the area of lung being suctioned. A bronchoscope though nearly $5 \mathrm{~mm}$ in diameter, may only have a $2 \mathrm{~mm}$ suction channel equivalent to a size 6 or 8 French suction catheter in aspiration power

Using the recently developed and experimental method of electrical impedance tomography $^{68}$ and suction pressures regulated to $120 \mathrm{~mm} \mathrm{Hg}$. Corley, A., Coruana, L. \& Barnett, $2010^{47}$ discovered that loss of positive airway pressure with disconnection of the ventilator to perform suctioning resulted in a loss of volume that only increased as suction was applied. The electrical impedance system, while non-invasive and non-toxic is not, it is conceded, very useful for detecting microatelectasis as may occur if a small airway was impacted by deep insertion of the endotracheal suction catheter. However this study reinforces that even at low vacuum / suction pressures a degree of lung volume loss is possible. 
In table 1 below details of lung volume loss at various reported suction levels are shown.

\section{Table 1.Volume loss from suctioning}

\begin{tabular}{|c|c|c|}
\hline Study & Vacuum Level & Lung Volume Loss Reported \\
\hline $\begin{array}{l}\text { Brandstater } \\
1969\end{array}$ & 33 mm Hg (unoccluded) & Average loss of compliance reported $50 \%$ \\
\hline $\begin{array}{l}\text { Egbert } \\
1963\end{array}$ & 15 to 20 Liter/min flow rate described & $\begin{array}{l}\text { Compliance } \\
\text { before suction }=47.7 \mathrm{ml} / \mathrm{cm} \mathrm{H} 2 \mathrm{O} \\
\text { after suction }=42.0 \mathrm{ml} / \mathrm{cm} \mathrm{H} 2 \mathrm{O} \\
(\mathrm{p}<.01)\end{array}$ \\
\hline Boothroyd 1996 & $\begin{array}{l}\text { Unregulated suction vs. } \\
120 \mathrm{~mm} \mathrm{Hg.}\end{array}$ & $\begin{array}{l}24 \% \text { developed right upper lobe collapse before } \\
\text { regulation. } \\
7 \% \text { developed right upper lobe collapse after } \\
\text { regulated suction }\end{array}$ \\
\hline $\begin{array}{l}\text { Cereda } \\
2001\end{array}$ & $100 \mathrm{~mm} \mathrm{Hg}$ & $\begin{array}{l}\text { Open suction loss } 1,200 \mathrm{ml} \\
\text { Closed suction loss } 140 \mathrm{ml} \text {. }\end{array}$ \\
\hline $\begin{array}{l}\text { Dyhr } \\
2003\end{array}$ & $400 \mathrm{~mm} \mathrm{Hg}$ & $\begin{array}{l}\text { EELV(end expiratory lung volume) } \\
\text { Before suction } 1550 \text { ml } \\
5 \text { min after suction minus } 11 \% \\
15 \text { min after suction minus } 9 \%\end{array}$ \\
\hline $\begin{array}{l}\text { Maggiore } \\
2003\end{array}$ & $150 \mathrm{~mm} \mathrm{Hg}$ & $\begin{array}{l}\text { EELV (end expired lung volume)reduction } \\
\text { Closed }=-531 \mathrm{ml} \\
\text { Quasi closed }=-733 \mathrm{ml} \\
\text { Open suction }=-1,400 \mathrm{ml}\end{array}$ \\
\hline $\begin{array}{l}\text { Fernandez } \\
2004\end{array}$ & $\begin{array}{l}150 \mathrm{~mm} \mathrm{Hg} \text {. } \\
\text { To } \\
200 \mathrm{~mm} \mathrm{Hg} \text {. }\end{array}$ & $\begin{array}{l}\text { Closed }=-386 \mathrm{ml} \\
\text { Quasi closed }=-497 \mathrm{ml} \\
\text { Open }=1,281 \mathrm{ml}\end{array}$ \\
\hline $\begin{array}{l}\text { Morrow } \\
2006\end{array}$ & $360 \mathrm{~mm} \mathrm{Hg}$ & $\begin{array}{l}\text { Dynamic compliance }(\mathrm{ml} / \mathrm{cmH} 2 \mathrm{O} / \mathrm{Kg} .) \\
\text { Before suction } 0.60(0.45-0.82) \\
\text { After suction } 0.56(0.41-0.75)\end{array}$ \\
\hline $\begin{array}{l}\text { Heinze } \\
2008\end{array}$ & $150 \mathrm{~mm} \mathrm{Hg}$. & 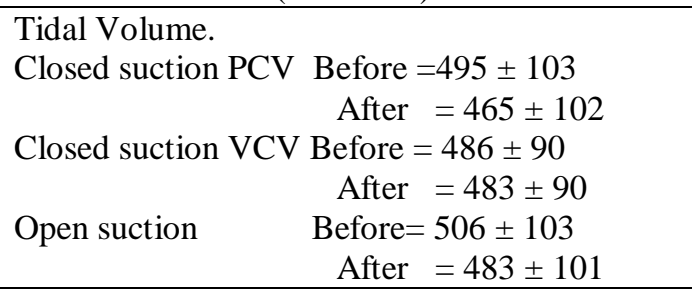 \\
\hline $\begin{array}{l}\text { Lindgren } \\
2008\end{array}$ & $200 \mathrm{~mm} \mathrm{Hg}(20 \mathrm{kPa}) \& 80 \mathrm{kPa}$ & $\begin{array}{l}\text { Derecruitment was pronounced during } \\
\text { suctioning and FRC decreased by }-479 \text { - } \\
472 \mathrm{ml}, \mathrm{P}<0.001 \text {. }\end{array}$ \\
\hline $\begin{array}{l}\text { Corley } \\
2010\end{array}$ & $120 \mathrm{~mm} \mathrm{Hg}$ & $\begin{array}{l}\text { Open = 2321 lung units lost } \\
\text { Closed = } 1416 \text { lung units lost }\end{array}$ \\
\hline
\end{tabular}




\section{The Haemodynamic effect of negative intra pulmonary pressure}

Going back in time to 1970 , Azmy Boutros ${ }^{51}$ reported that significant lung volume loss was probably responsible for the de-oxygenation seen when patients were suctioned at full wall pressure of $500 \mathrm{~mm} \mathrm{Hg}$ as compared with a similar period of apnoea.

In a an observational study by Walsh, J.M., Vanderwarf, C., Hoscheit, D. \& Fahey, P.J. $1989^{55}$ of ten acutely ill medical patients requiring positive pressure ventilation it was reported that the fall in venous oxygenation $(\mathrm{sVO} 2)$ was far greater than might have been anticipated from observing the fall in arterial oxygen saturation ( $\mathrm{Sa} \mathrm{O} 2$ ) during endotracheal suctioning. Using a vacuum level regulated to $120 \mathrm{~mm} \mathrm{Hg}$ creating a flow of 20 litres / min through the size 14 catheter this provides a valuable benchmark for a review of suitable suction / vacuum pressures. It was surmised that a decrease in intrathoracic pressure may result in venous pooling and resultant decrease in left ventricular preload.

In a study investigating the effect of repeated endotracheal suctioning on arterial blood pressure in 1991, Stone, K., Bell, S. \& Preusser, B ${ }^{69}$ using a vacuum / suction pressure that created a flow rate of 16 litres per minute through the size $14(4.7 \mathrm{~mm})$ suction catheters noted an increase in mean arterial pressure during endotracheal suctioning in patients following cardiac surgery. Findings suggested that care needs to be taken to avoid haemodynamic instability in these patients.

Following a review of the literature Celik and Elbas ${ }^{70}$ designed a study to determine if a regulated method of endotracheal suctioning may result in better patient outcomes in regard to haemodynamic variables. Although aware that a regulated suction / vacuum pressure of $150 \mathrm{~mm} \mathrm{Hg}$ was recommended for adult patients they had only the facility to reduce their vacuum level to $300 \mathrm{~mm} \mathrm{Hg}$. In Ankara, Turkey it was found that the introduction of a program of education and regulation both of the suction pressure and the practice of endotracheal suctioning better patient outcomes were achieved. "It can be said that a standard endotracheal suctioning procedure based on the best available evidence important for patients undergoing heart surgery." 
In a 2003 Scandinavian study by Leur, J.P., Zwaveling, J.H., Loef, B.G. \& Schans, C.P. ${ }^{29}$, perhaps better described as a comparison of deep versus shallow endotracheal suction, the suction pressure for both groups in this randomized control trial was reportedly 200 to 400 $\mathrm{mm} \mathrm{Hg}$. The on demand minimally invasive method proved to have fewer side effects than routine, deep endotracheal suctioning. Demonstrating the advantage of taking into account the narrowing of the bronchial tree as the catheter is inserted.

Eleven pediatric intensive care patients, between 6 and 17 years of age, were observed by Briassoulis, G., et al. in $2009^{71}$ and suctioning carried out at a regulated suction pressure of $250 \mathrm{~mm} \mathrm{Hg}$. Using a compact metabolic monitor the researchers determined that in well sedated children without significant lung pathology pulmonary mechanics and gas exchange returned to baseline as early as five minutes after suctioning.

Following the suctioning guidelines of the AARC and limiting vacuum pressure to less than 200mm Hg Seymour, C., Cross, B., Cooke, C., Gallop, R. \& Fuch, B ${ }^{72} .2009$ in their study found a higher incidence of haemodynamic disturbance in patients using closed suction systems when weaning from ventilatory support when compared to patients who were well sedated.

The study by Soares de Paula and Ceccon. $(2010)^{73}$ in a neonatal unit and suction vacuum pressure of 150 to $200 \mathrm{~mm} \mathrm{Hg}$ found little difference in outcomes regardless of whether open or closed suction method was employed. The study concluded that since there was little difference they could continue to use their usual method of open endotracheal suction. Of course one might argue that at these relatively high levels of suction pressure as opposed to those recommended by some systematic reviews both open and closed may be equally problematic with regard to haemodynamic changes and lung volume loss. The variable that is depth of catheter insertion is not described. But we may assume that suctioning beyond the end of the ET tube was avoided. It appears that a carefully observed and controlled method of suctioning as is described in study has benefits to the patient concerned. 


\section{Benefits of regulating vacuum exposure versus no regulation/free flow}

The systematic review of papers with regard to setting a regulated level of suction / vacuum level has found no evidence to support a view that suctioning from an unregulated wall suction outlet is a safe practice. Despite a notional view that a short suction episode at high vacuum may efficiently extract secretions, from the earliest days of mechanical ventilation, obvious tracheal trauma and adverse findings have been associated with very high levels of negative suction pressure applied to an endotracheal suctioning procedure.

Experience and expert opinion would advise that the high negative pressure should nevertheless be available in the case of a medical emergency involving the airway. 


\section{Chapter 4. Discussion}

From a systematic review of these studies in the human population we can synthesize a number of findings with regard to our outcomes of interest.

Firstly though, a brief review of the influence of animal studies in this field of Human physiology is necessary.

\section{Discussion of Animal Studies as background to review questions}

Animal studies have become controversial in recent times and their direct applicability to human physiology questioned particularly in regard to drug trials. It is however fair to suggest that a drug or procedure that has been found injurious in the animal subject is seldom replicated in human trials. In the field of respiratory physiology animal trials and studies still inform research today, the mammalian lung and its reaction to different modes of ventilation not being so different from that of Homo sapiens.

This review found animal studies of interest as background to our review question and they inform the discussion of human studies. These animal studies are presented in Appendix IV.

These will be described in relation to our outcomes of interest;

\section{Tracheobronchial Trauma}

The observation of tracheo bronchial trauma increasing in severity with increasing vacuum/suction pressure has led directly to previous and current recommendation that endotracheal suction pressures be limited to something less than $200 \mathrm{~mm} \mathrm{Hg}^{53}$. As we have mentioned previously later studies shift in focus to looking at haemodynamic variables and the loss of lung volume with different types of ventilation and the suction / vacuum pressure applied becomes a set parameter. 
The earliest study into techniques for minimizing trauma to the tracheobronchial tree after tracheostomy retrieved for this review was written by Plum and Dunning and appeared in the New England Journal of Medicine 1956. This was a study of animal and human subjects.

"The differences in gross appearance between the tracheobronchial trees of cats treated by observed (unregulated) suction and those receiving the regulated-pressure method was striking. Mucous membranes of the former group were hemorrhagic, oedematous and often ulcerated. These changes extended from the level of the tracheotomy down the point where the main stem bronchus had become too small to pass the catheter. The animals receiving observed suction, and kept overnight before being killed, had moderate to marked mucopurulent secretions coating the trachea and both main stem bronchi. The tracheobronchial trees of the regulated pressure treated animals by contrast, were moderately injected, showed little oedema and were not ulcerated." "Microscopical abnormalities were significant in the tracheobronchial trees of both the group treated by observed and that treated by the regulated-pressure method of suction. Epithelial erosion occurred in both groups. Erosion was greater in degree in the cats treated by observed suction, in which almost no tracheal epithelium remained. Submucous inflammation was present in both groups, but only the animals aspirated by the observed method showed extensive fragmentation or disappearance of submucosa; hemorrhagic submucossal infiltration was heavier in this group. .... The proximal part of the right main bronchus suffered the greatest damage in both groups of suctioned animals; in the regulatedsuction-treated group approximately 50per cent of the respiratory epithelium remained on a generally intact basement membrane whereas in the animals suctioned by the observed method, the entire mucous membrane was usually eroded down to the basal mucous glands or muscularis."

This rather long extract describes findings that have been replicated both at human autopsy as described in the same study and in subsequent animal studies usually performed in the canine model. Czarnik makes the point that that it is rarely possible to conduct histopathology on the tracheobronchial tree of Human subjects; this was the primary reason to use an animal subject from which results may be extrapolated. 
These studies in the animal model have informed the advice to limit suction vacuum pressures to less than $300 \mathrm{~mm} \mathrm{Hg}$ or more commonly 100 to $150 \mathrm{~mm} \mathrm{Hg}$ in the adult human patient.

Although anecdotal reports of suction trauma seen at autopsy and during bronchoscopy continue to circulate it may be considered unethical to conduct an experiment where patients were suctioned at high vacuum levels, greater than $300 \mathrm{~mm} \mathrm{Hg}$., as compared with regulated and generally recommended lower vacuum levels. It is conceded that despite advances in catheter design the very act of inserting a catheter into the bronchi may cause a degree of traumatic injury.

\section{Atelectasis, lung volume loss}

While it has in the twenty first century become a routine, at least in the literature, to turn on the suction regulator to a predetermined level of vacuum prior to endotracheal suctioning having observed the risk of tracheal trauma it was also apparent that negative pressure may develop within the lung causing deflation of the lung. Despite the recommendations of Rosen and Hillard that the suction catheter should occlude less than half the internal diameter of the endotracheal tube it was still observed that a recruitment manoeuvre was required to reinflate lost lung segments after the suctioning event. The animal model has allowed this phenomenon to be studied by removing many of the variables found in the hospitalised human population. This particularly true of the research coming out of Sweden $^{4,9,45}$.

It is worth noting that the use of Spiral CT scans to quantify lung volume loss during suctioning may expose the subjects to high levels radiation that will be unsuitable to repeat in human experiments.

The studies performed in the animal model continue to inform both practice and the future direction of human studies. 


\section{Discussion of included human studies}

\section{Trauma from suctioning}

Thambrian and Ripley ${ }^{74}$ in 1966 believed the tracheal ulceration and trauma they were observing in intubated neonates was related to the level of suction pressure being applied and devised a study in which kittens were exposed to increasing levels of suction or vacuum pressure from $50 \mathrm{~mm}$ of mercury to $300 \mathrm{~mm}$ of mercury confirming the observations of Plum and Dunning and recommending that pressures of 70 to $100 \mathrm{~mm}$ of mercury are adequate to remove the thickest of secretions and higher levels of suction pressure could be avoided.

Sackner and Lander ${ }^{52}$, in 1973, report that tracheal trauma has been a common finding at bronchoscopy particularly in the more easily penetrated right bronchus in patients receiving endotracheal suctioning noting that trauma can be seen at vacuum levels from 40 to $200 \mathrm{~mm} \mathrm{Hg}$ but increases with higher vacuum levels. Their report suggests not only limiting the vacuum pressure but using a redesigned catheter tip.

Kuzenski $^{53} 1978$ remains an oft quoted reference with regard to setting a regulated suction/ vacuum pressure after her study performed with dogs as subjects. Drawing directly from the findings of Plum and Dunning as well as Thambrian and Ripley ${ }^{74}$, Barbara Kuzenski was able to report that a suction pressure of $100 \mathrm{~mm} \mathrm{Hg}$ was just as effective at removing mucous as a pressure of $200 \mathrm{~mm} \mathrm{Hg}$.

The most recent study of this type was by Czarnik, Stone et $\mathrm{al}^{75}$ in 1991 . Herein it was reported that either continuous or intermittent suctioning at $200 \mathrm{~mm} \mathrm{Hg}$ produced measurable and significant tracheal trauma and reduced muco-cilliary clearance, again using a canine model. Continuous suction during catheter withdrawal was found to most effectively clear secretions.

These studies represent the primary evidence for setting a regulated suction / vacuum level of less than $200 \mathrm{~mm} \mathrm{Hg}$. 
It has been observed that mechanical trauma to the airways of patients experiencing endotracheal suctioning is exacerbated as suction / vacuum pressures are increased. Not only will high vacuum pressures increase the invagination and tearing of tissue with the suction catheter but also the shearing forces at alveolar level are increased.

Incautious insertion of a suction catheter deeply into the respiratory tree will cause trauma and those who have developed less invasive and controlled techniques have observed measureable benefits. Thankfully the "sink plunger" technique and the use of red rubber catheters have all but disappeared. Even so and despite the use of significantly improved catheters a degree of trauma from the very act of insertion may be present.

\section{Lung volume loss}

Lung volume loss continues to be measurable during endotracheal suctioning and this is most likely responsible for a number of the hemodynamic and gas exchange abnormalities observed during endotracheal suctioning.

From table 1 it is easy to see that despite our inability to directly compare some study results due to various measuring and reporting strategies, the degree of lung volume loss is intimately related to the vacuum applied and the fluid dynamics of the system as the various pressures within the system try to equalise.

The air flow created through the suction catheter at different suction pressures using a suction outlet that complies with international standards will be verisimilar to those described in those papers where this is a reported variable. 
Table 2. Flow rates through suction catheters at reported regulated vacuum pressures.

\begin{tabular}{|l|l|l|l|}
\hline Author & Catheter size & Free Air Flow & Regulated Vacuum \\
\hline Frengley & $14 \mathrm{Fr}$ & $40 \mathrm{~L} / \mathrm{min}$ & $386 \mathrm{~mm} \mathrm{Hg}$ \\
\hline Walsh J M & $14 \mathrm{Fr}$ & $20 \mathrm{~L} / \mathrm{min}$ & $120 \mathrm{~mm} \mathrm{Hg}$. \\
\hline Brown S E & $14 \mathrm{Fr}$ & $20 \mathrm{~L} / \mathrm{min}$ & $120 \mathrm{~mm} \mathrm{Hg}$. \\
\hline Egbert L E & $12 \mathrm{Fr}$ & 15 to $20 \mathrm{~L} / \mathrm{min}$ & \\
\hline Stone K & $14 \mathrm{Fr}$ & $16 \mathrm{~L} / \mathrm{min}$ & \\
\hline Baun M & $14 \mathrm{Fr}$ & 17 to $30 \mathrm{~L} / \mathrm{min}$ & Wall suction \\
\hline Fell T & & $16 \mathrm{~L} / \mathrm{min}$ & $66 \mathrm{~mm} \mathrm{Hg}$. \\
\hline Arbon D(author) & $14 \mathrm{Fr}$ & $56 \mathrm{~L} / \mathrm{min}$ & $570 \mathrm{~mm} \mathrm{Hg}$. \\
\hline & & & \\
\hline
\end{tabular}

As these flows are imposed within the lung, entrainment will create a negative pressure beyond the tip of the catheter that will increase with the resistance to return airflow the more deeply the catheter is inserted into the respiratory tree. This is in keeping with the reported findings of the examined studies.

In the commonly employed positive pressure ventilation the majority of volume loss is seen as the patient is removed from the ventilator and then further volume will be removed as suctioning is commenced. Depending on the ventilator settings employed this loss of positive end expiratory pressure and to some extent suction volume loss may be reduced by using a closed suction system so that the patient will remain connected to the ventilator. 


\section{Haemodynamic changes}

Form the review of these studies haemodynamic changes with regard to setting an appropriate regulated suction / vacuum pressure are apparently mediated by these lung volume changes. The degree of venous shunting as blood returning to the heart is increased, squeezed from a collapsed area of lung is seen as a haemodynamic variable. Otherwise the stimulation of a cough or bronchospasm as well as the degree of distress elicited from the very act of suctioning ${ }^{30}$ will all impact on the haemodynamic response. A very good explanation of these potential haemodynamic changes appears in a 1984 study by Baun, Franz and Lindsay ${ }^{54}$.

\section{The role of previous reviews and Guidelines}

Existing reviews and guideline were sought as part of the background preparation for this review. The review itself came out of a desire to reconcile our current practice of not limiting or regulating suction pressure for the performance of endotracheal suctioning with the current published guidelines.

A collection of systematic reviews, meta-analyses, and guidelines and their recommendations as to pressure setting is appended (Appendix I), and relevant references extracted from these existing publications are appended (Appendix VII). These reviews were examined to extract the current recommendations for practice and the level of evidence reported to support those findings. Further a hand search of the references was made to extract any papers representing original research that may be of use to the review.

\section{Mixing of findings in Adults and Children}

No differentiation between studies within the adult or pediatric and neonatal setting was made as both the levels of suction vacuum applied and the resultant results with regard to our outcomes of interest remain consistent throughout the entire spectrum of cases. More interest and research appears to be under taken in the pediatric area but the effect of increasing vacuum / suction levels are equally important to the frail and elderly. 


\section{Limitations of the review}

A limitation of the current review may be its reliance on human studies as primary sources.

This has meant that a diverse group of research methodologies and reporting methods have been combined with a view to extracting data with regard to the outcomes of interest.

As a direct consequence any study that involved human subjects and reported results with respect to suction vacuum pressure set and its effect on one or more of the outcomes of interest such as increasing trauma, lung volume loss or hemodynamic changes was included where possible.

For example when looking at the amount of lung volume loss reported at different levels of vacuum or suction pressure. This is variously reported in terms of functional residual capacity, compliance, end expired volume or in the case of electrical impedance tomography, simply "units".

The necessity of conducting a search with historical papers going back to the earliest days of mechanical ventilation has highlighted that the demands of experimental quality has varied over time. Nevertheless all included papers are from reputable peer reviewed journals and were the best available sources of their time with strong internal validity.

Despite these limitations it has been of some comfort to realise all the findings ultimately reflect the effect of those laws of physics first promulgated in the $17^{\text {th }}$ century. 


\section{Chapter 5.}

\section{Conclusion}

It is clear then that the effect of vacuum pressure imposed upon the lung and described in the studies performed in a human population are in keeping with physical first principles as supported by various animal studies dating back to the 1950's.

While the mechanically ventilated patient either with an endotracheal tube or tracheostomy will require assistance to remove accumulated airway secretions, endotracheal suction is a procedure with inherent risk to the patient from airway trauma, haemodynamic disturbance and disruption to gas exchange.

Previous Meta -analyses systematic reviews and expert clinical guidelines have advocated setting a regulated suction / vacuum level prior to performing endotracheal suctioning although they consistently give a low value to the evidence supporting these recommendations. The reason for this, it could be argued, lies in the appraisal process and the changes in research methodology and reporting over time.

Despite this room for practice improvement and in some cases simply implementation of these recommendations remains.

Dryr, Bonde and Lasson ${ }^{62}$ in 2002, suggested that vacuum pressures of up to $400 \mathrm{~mm} \mathrm{Hg}$ are sometimes used in Scandinavia while recommending that, at $400 \mathrm{~mm} \mathrm{Hg}$, ETS be avoided if possible considering the subsequent effect on lung volume.

Following a Scandinavian survey into the practices of endotracheal suctioning in 2005 by Grivens et $\mathrm{al}^{76}$, an editorial by A Larsson appeared entitled; -'Inhale, suction and close the lung: a common clinical practice in Scandinavian intensive care units?" ${ }^{40}$ Herein it was reported that despite previous recommendations, some intensive care units continue to use a vacuum pressure of as high as $300 \mathrm{~mm} \mathrm{Hg}$. 
With improvements in lung imaging and data collection it has been found that endotracheal suctioning has adverse effects on lung volume and haemodynamics previously unsuspected and have called for further review of this routine procedure. ${ }^{4,77}$

Interestingly as time goes by the references with regard to setting a regulated level of suction / vacuum level become less convincing, so that for example the latest American Association for Respiratory Care (AARC) guideline 2010 may only reference a single text to support a recommendation of less than 150mm Hg for adult patients. The 1993 edition by Branson ${ }^{64}$ cites two texts. Over time the evidence becomes expert opinion from someone who had read the original evidence. This is an indication that in much of the world setting a regulated vacuum / suction pressure prior to suctioning is just an accepted part of the routine but is disconcerting for a reviewer who may confine a search to the current century.

Limiting a literature search to recent works will downgrade the level of evidence in a systematic review as it was back in the early days of mechanical ventilation that much of the ground breaking research was performed. Only a search of the references to the references or a broader search of historical and original research has captured these papers and increased the level of evidence accordingly.

Similarly confining a search to human studies or ignoring bench test or invitro findings may remove invaluable physiological and physical research of relevance to a comprehensive understanding of the subject. It has been disappointing to see how this knowledge has failed to be followed up in practice but it is only in fairly recent times that many of these papers have found their way into readily accessible data bases and Nurses in Universities able and encouraged to study them.

Even so one of my original textbooks from 1979 recommends setting a regulated level of vacuum on the suction regulator prior to endotracheal suctioning and this is a general nursing text ${ }^{78}$. 


\section{The best available evidence}

The best evidence for setting a regulated suction / vacuum pressure prior to endotracheal suctioning then comes out of more than fifty years of small heterogeneous studies by interested and concerned health professionals. Taken as a body of work and examined chronologically they point indubitably to the reasonable response that the suction / vacuum pressure presented to the lung during endotracheal suctioning should be controlled regulated and carefully assessed. The study by Plum and Dunning in human and animal cases and replicated in animal models on several occasions since demonstrate plainly the increasing risk of tracheobronchial trauma with increasing vacuum levels and the recommendation to limit this to less than $200 \mathrm{~mm} \mathrm{Hg}$.

The observation that lung volume and functional residual capacity was lost to suctioning was observed in the 1960s and Rosen and Hillard suggested limiting the size of the occluding suction catheter within the airway tree. Even so it has not always been made plain that large negative pressures could be imposed as the catheter was inserted deeply into a narrowing bronchiole with large airflows from high driving pressures.

Methods were devised to reinstate lost lung segments and recruitment manoeuvres of various kinds, on and off, ventilator were studied.

More recently it has been hypothesized that this opening and closing of lung units may itself be a cause of trauma at the alveolar level reenergizing the research into optimal levels of endotracheal suction pressure and the performance of this one time routine procedure.

Remembering that there is only approximate consistency among suppliers of suction regulators and piped suction or suction machines may present various flow rates. It has been suggested that optimizing flow for a level of vacuum is desirable but very high flow rates through the system will cause a venturi effect within the lung itself as the suction catheter acts as an annulus within the bronchi resulting in a net loss of lung volume. 
Flow rates of 15 to 20 litres of air through the suction catheter have been reported in various studies at recommended vacuum occlusion pressures and would appear to be adequate for the task of clearing airway secretions in the adult subject.

This review is in agreement with several reviews and meta-analysis of endotracheal suctioning where in a regulated vacuum pressure is described as $80-100 \mathrm{~mm} \mathrm{Hg}$ in neonates and less than $150 \mathrm{~mm} \mathrm{Hg}$ routinely in Adults. These recommendations appear in professional guidelines by the American Association for Respiratory Care, The Australian College of Critical Care Nurses, the Joanna Briggs Institute guide to evidence based practice and several more and yet the challenge remains, it appears, to bring this evidence to practice.

We have seen from the studies examined concerning human subjects that even with suction I vacuum regulated to these recommended levels a degree of lung volume loss and trauma are reported findings.

While no safe maximum has been determined; there is no evidence to support suctioning an artificial airway from an unregulated wall suction outlet.

What is the optimal level of vacuum / suction pressure to apply during the course of endotracheal suctioning?

As much as necessary and as little as possible.

\section{Implications for research}

It is always tempting to suggest that a proper randomised controlled trial of various aspects of endotracheal suctioning raised in the review be conducted.

Much of the current primary research into the effects of endotracheal suctioning has been performed in an animal model and may not be considered for inclusion in a systematic review under normal circumstances. We believe this may have important implications for further study both ethically and scientifically.

A primary research study looking at the issues of bringing existing evidence to practice (Knowledge translation) that arise from this review may be useful. 


\section{Implications for practice}

As a direct consequence of this review a program of bringing this evidence to practice in areas where this important parameter in the endotracheal suction process is not considered or given much weight should be undertaken.

It is hoped that this review although formally limited to an examination of studies concerning human subjects has highlighted the importance of this parameter when examining the effects of endotracheal suctioning.

It is in the interests of patients, health care practitioners and researchers that safety and consistency is achieved it this regard.

Important questions of patient safety are raised if a practice is found to be outside what might be considered safe on an international level.

\section{Contribution to knowledge}

This review has highlighted the importance of setting a regulated suction/ vacuum pressure prior to endotracheal suctioning in the intensive care unit.

It has highlighted the importance of conducting an historic study of the research and findings with regard to setting a regulated suction / vacuum pressure for endotracheal suctioning as confining a literature search to, for example, the present century will miss important and unequivocal findings from the past.

For those practitioners already setting a recommended level of suction / vacuum pressure prior to endotracheal suctioning it should be noted that even at the pressures mentioned above the possibility of lung volume loss, haemodynamic changes and trauma to the airways are reported. Individual attention to vacuum strength and depth of catheter insertion should be made for each patient.

The combination of detailed background information from anatomy, physiology and physical science with a comprehensive search of the literature over the last seventy years has provided the conditions for the appropriate synthesis of the evidence that is directly relevant to clinical practice. 
Appendices 


\section{Appendix I. Existing Guidelines, meta-analysis, systematic reviews}

\begin{tabular}{|c|c|c|c|c|}
\hline References Details & $\begin{array}{l}\text { Type of } \\
\text { Publication }\end{array}$ & Objectives & Results/Conclusions & Reviewer Comments \\
\hline $\begin{array}{l}\text { Patricia L Carroll. } \\
\text { The principles of } \\
\text { vacuum and its use } \\
\text { in the hospital } \\
\text { environment. } \\
\text { Monograph. Ohio } \\
\text { Medical Corporation } \\
\text { Form No. SOT } 645 \\
99510 \\
\text { Reprinted: } 030607 \\
\text { Printed in U.SA } \\
\text { Ohio Medical } \\
\text { Corporation }\end{array}$ & $\begin{array}{l}\text { Technical } \\
\text { review }\end{array}$ & $\begin{array}{l}\text { A review of the principles of } \\
\text { vacuum and its application in } \\
\text { various hospital settings } \\
\text { including recommendations for } \\
\text { suitable pressures for various } \\
\text { applications including } \\
\text { Endotracheal suctioning }\end{array}$ & $\begin{array}{l}\text { The least pressure required to draw } \\
\text { secretions into the collection vessel. } \\
\text { Recommended pressures are } 80 \text { to } \\
100 \mathrm{~mm} \mathrm{Hg} \text {. Negative pressure. }\end{array}$ & \\
\hline
\end{tabular}




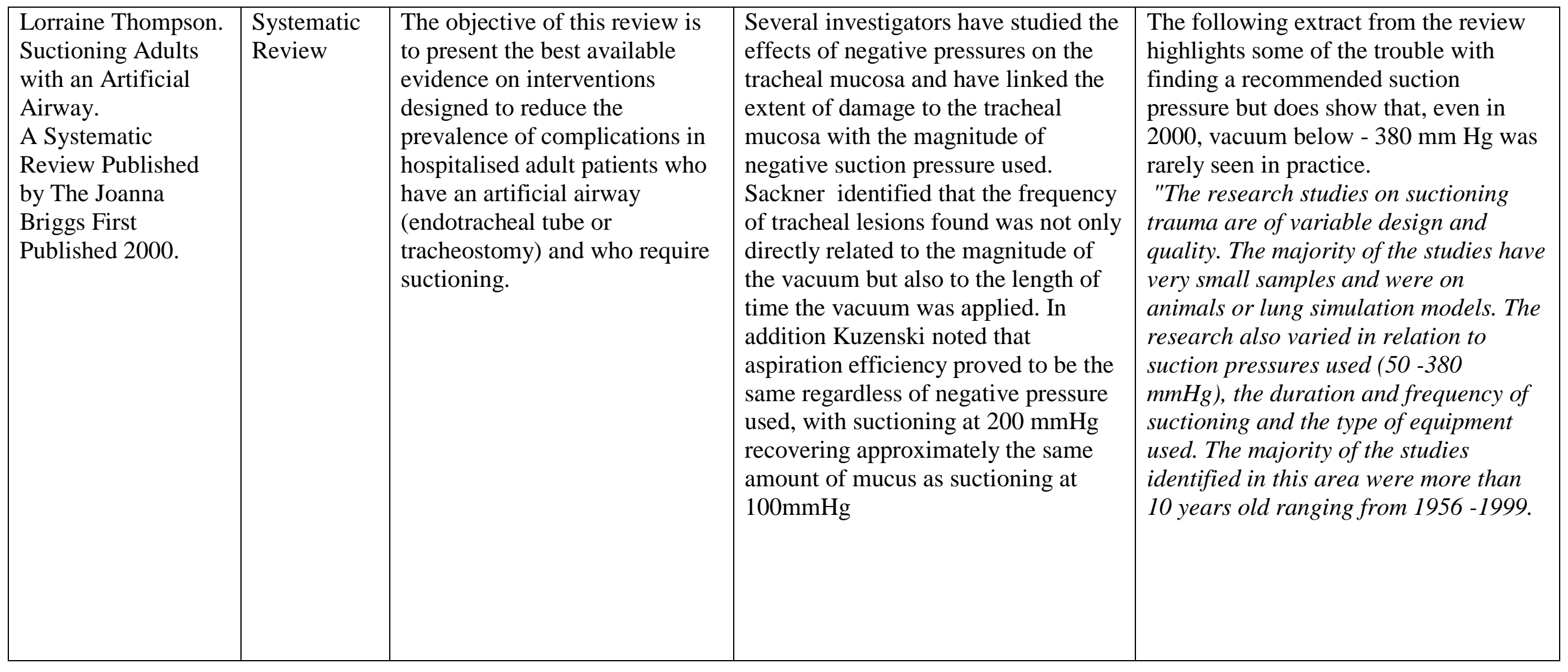




\begin{tabular}{|c|c|c|c|c|}
\hline $\begin{array}{l}\text { Carsten M. Pedersena, Mette } \\
\text { Rosendahl-Nielsenb, } \\
\text { Jeanette Hjermindc, Ingrid } \\
\text { Egerodd. Endotracheal } \\
\text { suctioning of the adult intubated } \\
\text { patient-What is the evidence? } \\
\text { Intensive and Critical Care } \\
\text { Nursing (2009) } 25,21-30\end{array}$ & $\begin{array}{l}\text { A Meta analysis of } \\
\text { current research } \\
\text { findings }\end{array}$ & $\begin{array}{l}\text { The aim of this article } \\
\text { was to review the } \\
\text { available literature } \\
\text { regarding endotracheal } \\
\text { suctioning of adult } \\
\text { intubated intensive } \\
\text { care patients and to } \\
\text { provide evidence- } \\
\text { based } \\
\text { recommendations }\end{array}$ & $\begin{array}{l}\text { The major recommendations are } \\
\text { suctioning only when necessary, } \\
\text { using a suction catheter occluding } \\
\text { less than half the lumen of the } \\
\text { endotracheal tube, using the lowest } \\
\text { possible suction pressure, inserting } \\
\text { the catheter no further than carina, } \\
\text { suctioning no longer than } 15 \mathrm{~s} \text {, } \\
\text { performing continuous rather than } \\
\text { intermittent suctioning, avoiding } \\
\text { saline lavage, providing } \\
\text { hyperoxygenation before and after } \\
\text { the suction procedure, providing } \\
\text { hyperinflation combined with hyper } \\
\text { oxygenation on a non-routine basis, } \\
\text { always using aseptic technique, and } \\
\text { using either closed or open suction } \\
\text { systems. } \\
\text { It is recommended using } \\
\text { the lowest possible suction pressure } \\
\text { during endotracheal suctioning, } \\
\text { usually } 80-120 \text { mmHg. } \\
\text { A negative pressure of } 200 \mathrm{mmHg} \\
\text { may be applied provided that the } \\
\text { appropriate } \\
\text { suction catheter size is used. }\end{array}$ & A recent and oft cited reference. \\
\hline
\end{tabular}




\begin{tabular}{|c|c|c|c|c|}
\hline $\begin{array}{l}\text { AARC Clinical Practice } \\
\text { Guidelines Endotracheal } \\
\text { Suctioning of Mechanically } \\
\text { Ventilated Patients } \\
\text { With Artificial Airways } 2010 \\
\text { Respiratory Care. June } 2010 \\
\text { Vol.44 No.6 }\end{array}$ & $\begin{array}{l}\text { A guide to practice } \\
\text { based on a } \\
\text { systematic review of } \\
\text { current literature }\end{array}$ & & $\begin{array}{l}\text { Experimental data to support an } \\
\text { appropriate maximum } \\
\text { suction level are lacking. } \\
\text { Negative pressure of } 80-100 \mathrm{mmHg} \\
\text { in neonates } 18 \text { and less than } \\
\text { 150mmHg in adults have been } \\
\text { recommended. } \\
\text { The recommendation for pressure } \\
\text { setting is essentially unchanged } \\
\text { from the } 1993 \text { version which states } \\
\text { that ' The suction pressure should } \\
\text { be set as low as possible and yet } \\
\text { effectively clear secretions } \\
\text { Experimental data to support an } \\
\text { appropriate maximum suction level } \\
\text { are lacking. Some textbooks cite a } \\
\text { safe limit of } 100 \text { - } 150 \text { mm Hg. but } \\
\text { do not reference their } \\
\text { recommendations." }\end{array}$ & $\begin{array}{l}\text { We do however see a } \\
\text { consistency and acceptance that } \\
\text { the least required to do the } \\
\text { work is preferable. } \\
\text { Significantly not regulating the } \\
\text { suction is not an option either. }\end{array}$ \\
\hline $\begin{array}{l}\text { Kaye Rolls, Kelvin Smith, } \\
\text { Pauline Jones } \\
\text { Megan Tuipulotu .Suctioning an } \\
\text { Adult with a Tracheal Tube } \\
\text { NSW Health Statewide } \\
\text { Guidelines for Intensive } \\
\text { Care.NSW Health } \\
\text { NSW Intensive Care } \\
\text { Coordination and Monitoring } \\
\text { Unit } 2007 .\end{array}$ & a systematic review & $\begin{array}{l}\text { The purpose of this set } \\
\text { of Guidelines is to } \\
\text { outline the best } \\
\text { available evidence } \\
\text { related to artificial } \\
\text { airway suctioning } \\
\text { procedures }\end{array}$ & $\begin{array}{l}\text { In addition to these aspects, expert } \\
\text { opinion suggests limiting the } \\
\text { suction procedure to a maximum of } \\
\text { three passes (of the suction } \\
\text { catheter) using a negative } \\
\text { pressure setting of between 100- } \\
150 \mathrm{mmHg}\end{array}$ & \\
\hline
\end{tabular}




\begin{tabular}{|l|l|l|l|}
\hline $\begin{array}{l}\text { HYUNSOO OH, WHASOOK } \\
\text { SEO. A meta-analysis of the } \\
\text { effects of various interventions } \\
\text { in preventing endotracheal } \\
\text { suction-induced hypoxemia. }\end{array}$ & Meta analysis & $\begin{array}{l}\text { The purpose of this } \\
\text { study was to clarify the } \\
\text { effects of interventions } \\
\text { that were applied to } \\
\text { prevent endotracheal } \\
\text { suction-induced } \\
\text { hypoxia by meta- } \\
\text { analysis. }\end{array}$ & $\begin{array}{l}\begin{array}{l}\text { Suctioning was commonly } \\
\text { sustained for }<15 \text { seconds using } \\
\text { pressures of } 80 \\
\text { to } 120 \text { mmHg and with size } 14 \\
\text { French catheters. Flow rates of } 15 \\
\text { to 22 litres/min described. }\end{array} \\
\end{array}$ \\
\hline
\end{tabular}




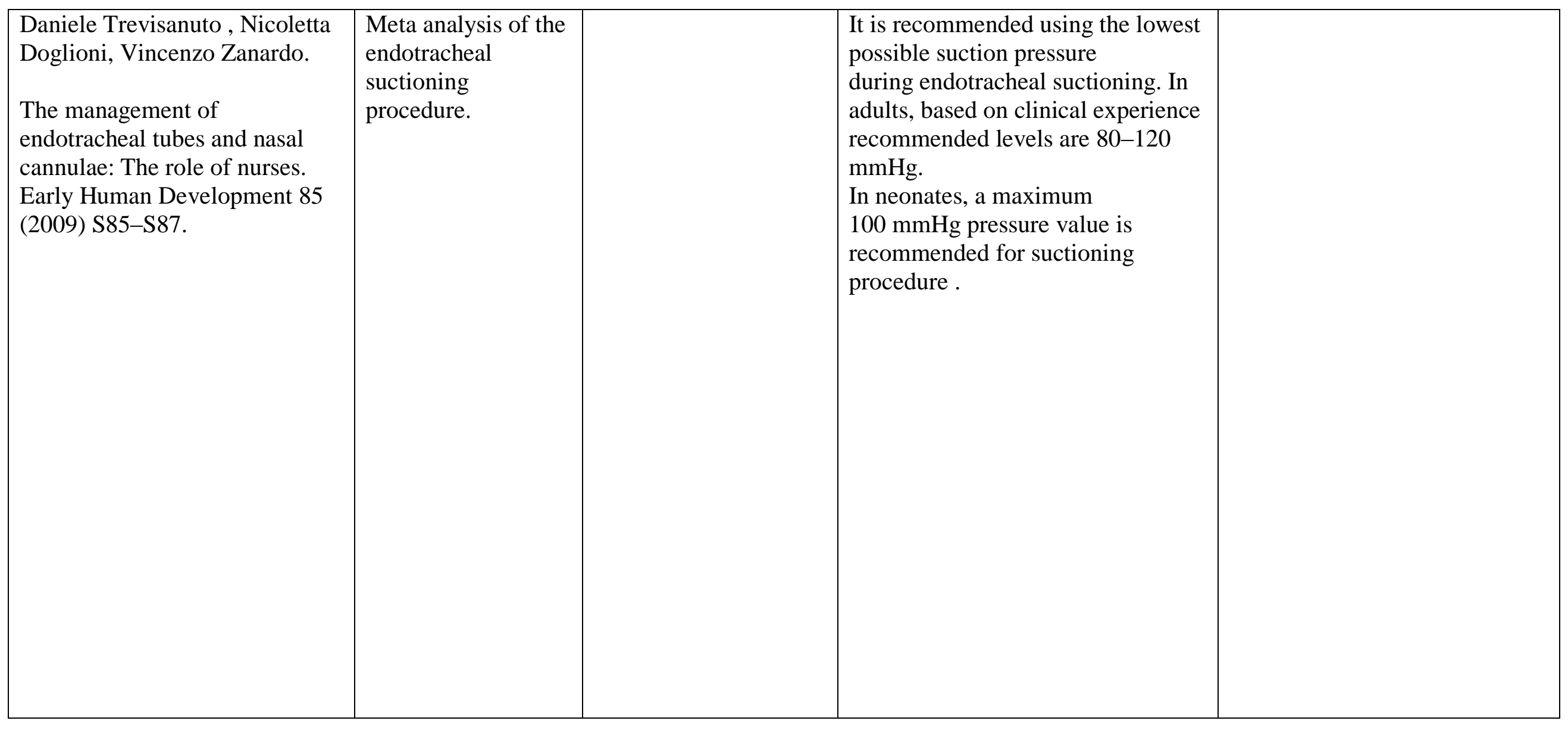




\begin{tabular}{|l|l|l|l|}
\hline $\begin{array}{l}\text { Brenda M. Morrow, Andrew C. } \\
\text { Argent. } \\
\text { A comprehensive review of } \\
\text { pediatric endotracheal } \\
\text { suctioning: } \\
\begin{array}{l}\text { Effects, indications, and clinical } \\
\text { practice. }\end{array}\end{array}$ & $\begin{array}{l}\text { The purpose of this } \\
\text { study was to provide a } \\
\text { comprehensive, } \\
\text { evidence-based review } \\
\text { of pediatric } \\
\text { endotracheal } \\
\text { suctioning: effects, } \\
\text { indications, and } \\
\text { clinical practice. }\end{array}$ & $\begin{array}{l}\text { Medical and paramedical staff } \\
\text { should use the lowest pressure that } \\
\text { effectively } \\
\text { removes the secretions with the } \\
\text { least adverse clinical reaction. } \\
\text { Suction } \\
\text { pressures should be at least } \\
\text { mm Hg. }\end{array}$ & $\begin{array}{l}\text { Higher suction / vacuum } \\
\text { pressures appear in Southern } \\
\text { Australia. }\end{array}$ \\
& & \\
\end{tabular}




\begin{tabular}{|c|c|c|c|c|}
\hline $\begin{array}{l}\text { Bronwyn A. Couchmana, } \\
\text { Sharon M. Wetzig, Fiona M. } \\
\text { Coyerc,*, Margaret K. } \\
\text { Wheelerc. Nursing care of the } \\
\text { mechanically ventilated patient: } \\
\text { What does the evidence say? } \\
\text { Part one. Intensive and Critical } \\
\text { Care Nursing (2007) } 23,4-14\end{array}$ & A literature review & $\begin{array}{l}\text { To identify the } \\
\text { evidence supporting } \\
\text { practice }\end{array}$ & $\begin{array}{l}\text { Evidence is lacking to suggest an } \\
\text { exact maximum pressure to be } \\
\text { applied, however pressures of } \\
\text { 200mmHg or greater have been } \\
\text { associated with tracheal damage } \\
\text { (Day et al., 2002; Donald et al., } \\
\text { 2000). } \\
\text { Recommendations for acceptable } \\
\text { suction pressures given in the } \\
\text { literature range from } 80 \text { to } \\
\text { 170mmHg (Day et al., 2002; } \\
\text { Donald et al., 2000). }\end{array}$ & \\
\hline $\begin{array}{l}\text { Tina Moore. Suctioning } \\
\text { techniques for the removal of } \\
\text { respiratory secretions. The } \\
\text { Royal College of Nursing. } \\
\text { Continuing Professional } \\
\text { Development guideline. } \\
\text { Nursing Standard } \\
\text { 2003.November } 12 . \text { Vol.18 no.9. } \\
\text { 49-55. }\end{array}$ & $\begin{array}{l}\text { Clinical practice } \\
\text { guideline }\end{array}$ & $\begin{array}{l}\text { An educational } \\
\text { resource and review } \\
\text { sponsored by the } \\
\text { Royal College of } \\
\text { Nursing Britain. }\end{array}$ & $\begin{array}{l}80 \text { to } 120 \mathrm{~mm} \mathrm{Hg} \text { negative pressure } \\
(12-16 \mathrm{kPa}) \text { More tenacious } \\
\text { secretions may require an increased } \\
\text { vacuum up to } 200 \mathrm{~mm} \mathrm{Hg} \text {. }\end{array}$ & \\
\hline
\end{tabular}




\begin{tabular}{|c|c|c|c|c|}
\hline $\begin{array}{l}\text { Tina Day, Sarah Farnell and } \\
\text { Jenifer Wilson-Barnett. } \\
\text { Suctioning: a review of current } \\
\text { research recommendations. } \\
\text { Intensive and Critical Care } \\
\text { Nursing (2002) 18, 7 9-8 9. }\end{array}$ & A literature review & $\begin{array}{l}\text { This paper reviews the } \\
\text { literature relating to } \\
\text { suctioning to identify } \\
\text { current research } \\
\text { recommendations for } \\
\text { safer suctioning } \\
\text { practice. }\end{array}$ & $\begin{array}{l}\text { Using high negative pressures does } \\
\text { not mean that more secretions will } \\
\text { be aspirated, therefore } \\
\text { limiting pressures to between } 80 \\
\text { and } 150 \mathrm{mmHg} \text { is recommended }\end{array}$ & $\begin{array}{l}\text { Contains an thorough review of } \\
\text { the papers describing suction } \\
\text { pressures }\end{array}$ \\
\hline $\begin{array}{l}\text { Stephen Ashurst. Suction } \\
\text { therapy in the } \\
\text { critically ill patient. British } \\
\text { Journal of Nursing.1993. Vol } 1 . \\
\text { No } 10 .\end{array}$ & Clinical Review & $\begin{array}{l}\text { An educational review } \\
\text { of use of suctioning in } \\
\text { respiratory care. }\end{array}$ & $\begin{array}{l}\text { high vacuum suction } \\
\text { (13-16 kPa) (Allen, 1988; } \\
\text { Lippincott, 1990). } 80 \text { tp } 120 \mathrm{~mm} \\
\mathrm{Hg} \text {. }\end{array}$ & $\begin{array}{l}\text { Interesting that Ashurst in } 1993 \\
\text { regarded "high Vacuum" as } 80 \\
\text { to } 120 \mathrm{~mm} \mathrm{Hg} \text { ) }\end{array}$ \\
\hline
\end{tabular}




\begin{tabular}{|l|l|l|l|}
\hline $\begin{array}{l}\text { Elaine Manderson, Clinical } \\
\text { Practice Guideline } \\
\text { Suctioning via an artificial } \\
\text { airway. }\end{array}$ & literature review \\
$\begin{array}{l}\text { Chelsea and Westminster } \\
\text { Hospital. NHS. August 2006. }\end{array}$ & Clinical Guideline. & $\begin{array}{l}\text { Applied negative pressure should } \\
\text { be between 80-150 mmHg (10.6- } \\
\text { 20kPa) as higher pressures have } \\
\text { been shown to cause trauma, } \\
\text { hypoxemia, atelectasis and catheter } \\
\text { collapse. }\end{array}$ & $\begin{array}{l}\begin{array}{l}\text { Jane } \\
\text { this guide after I had made } \\
\text { enquires as to the practice at the } \\
\text { hospital associated with N Soni } \\
\text { of Imperial College and co } \\
\text { editor of Oh's Intensive Care } \\
\text { Manual }\end{array} \\
\text { This guide is similar to those } \\
\text { UKroughout the NHS. }\end{array}$ \\
\end{tabular}




\begin{tabular}{|c|c|c|c|}
\hline $\begin{array}{l}\text { ACCN's Critical Care Nursing. } \\
\text { Elsevier } 2007 . \\
\text { Cuthbertson S, Kelly M. } \\
\text { Support of respiratory function. } \\
\text { In: Elliott D, Aitken L, } \\
\text { Chaboyer W, editors. Critical } \\
\text { Care Nursing: } \\
\text { Elsevior; 2007. p. } 280-1 .\end{array}$ & Textbook Chapter & $\begin{array}{l}\text { Insertion and } \\
\text { withdrawal of the } \\
\text { suction catheter } \\
\text { should not exceed } \\
10 \text { second, with no } \\
\text { more than three } \\
\text { attempts in one } \\
\text { procedure using } \\
100 \text { to } 150 \text { mm Hg } \\
\text { vacuum. Higher } \\
\text { pressures provide a } \\
\text { more effective } \\
\text { clearance in a } \\
\text { shorter time frame } \\
\text { with only one } \\
\text { sweep required but } \\
\text { adverse effects } \\
\text { include trauma, } \\
\text { hypoxemia and } \\
\text { atelectasis. } \\
100 \text { to } 150 \text { mm Hg } \\
\text { negative pressure. }\end{array}$ & $\begin{array}{l}\text { The Official Australian College of Critical Care } \\
\text { Nurses Guide. Only a couple of references; Wood } \\
\text { C, Endotracheal Suctioning; a Literature Review. } \\
\text { Intens Crit Care Nurs 1998; 14: 124-36. } \\
\text { National Guideline Clearing House. } \\
\text { Naso-tracheal suctioning-2004 revision[cited Oct } \\
\text { 2005]. } \\
\text { www.guideline.gov/summary/summary.aspx?view } \\
\text { id-1\&doc id=6514. } \\
\text { Morrow B, Futter M Argent A, Endotracheal } \\
\text { suctioning; from principals to practice.. Int Care } \\
\text { Med 2004; 30(6): 1167-74. }\end{array}$ \\
\hline
\end{tabular}




\title{
Appendix II. JBI Critical appraisal tools
}

\author{
NOTE:
}

This appendix is included on pages 63-65 of the print copy of the thesis held in the University of Adelaide Library. 


\section{Appendix III. JBI Data extraction form}

NOTE:

This appendix is included on pages 66-67 of the print copy of the thesis held in the University of Adelaide Library. 


\section{Appendix IV. Animal studies for background and discussion}

The Animal studies examined, in chronological order

\begin{tabular}{|c|c|c|c|c|c|c|}
\hline Study & Type & Description & $\begin{array}{l}\text { Suction/vacuum } \\
\text { level }\end{array}$ & Outcomes of interest & Subjects & Reviewers Comment \\
\hline $\begin{array}{l}\text { Hammouda M, } \\
\text { Wilson W H. Reflex } \\
\text { slowing of } \\
\text { respiration } \\
\text { accompanying } \\
\text { changes in the } \\
\text { intrapulmonary } \\
\text { pressure. J P } \\
\text { Physic.org } 1936 . \\
\text { J Pysiol. } 1936 .\end{array}$ & $\begin{array}{l}\text { Qasi- } \\
\text { experimental }\end{array}$ & $\begin{array}{l}\text { It is thought that } \\
\text { reflex slowing } \\
\text { of heart rate } \\
\text { occurs when the } \\
\text { lung is } \\
\text { completely } \\
\text { collapsed. In a } \\
\text { Dog neg -40mm } \\
\text { Hg. HR } \\
\text { decreases } 90 \text { to } \\
39 \text { BPM. Whilst } \\
\text { neg } 80 \text { mm Hg } \\
\text { completely } \\
\text { collapses lung. }\end{array}$ & Minus 14 mm Hg. & $\begin{array}{l}\text { A negative intra } \\
\text { pulmonary pressure of } \\
14 \text { mm Hg. Leads to } \\
\text { reflex slowing of heart } \\
\text { rate and just below this } \\
\text { the lung is completely } \\
\text { collapsed. The } \\
\text { experimental evidence } \\
\text { adduced in Section } 4 \text { can } \\
\text { be accepted as proving } \\
\text { that pressure changes } \\
\text { unaccompanied by } \\
\text { changes in the volume of } \\
\text { the lungs or air passages } \\
\text { have no excitatory effect } \\
\text { on the vagus } \\
\text { terminations, and that } \\
\text { therefore any reflex } \\
\text { slowing or acceleration } \\
\text { of the }\end{array}$ & Rabbits & $\begin{array}{l}\text { In man it is thought that a } \\
\text { negative pressure within the } \\
\text { lung of some } 50 \mathrm{~cm} \mathrm{H} 2 \mathrm{O} \\
\text { will be impossible to } \\
\text { breathe against. }\end{array}$ \\
\hline
\end{tabular}




\begin{tabular}{|c|c|c|c|c|c|c|}
\hline & & & & $\begin{array}{l}\text { respiratory rhythm must } \\
\text { be due to changes in the } \\
\text { shape or stress to } \\
\text { which the lungs, the air } \\
\text { passages or their } \\
\text { surroundings are } \\
\text { subjected. }\end{array}$ & & \\
\hline $\begin{array}{l}\text { Thambrian A K, } \\
\text { Ripley S H. } \\
\text { Observations on } \\
\text { tracheal trauma } \\
\text { following suctioning } \\
\text { - an experimental } \\
\text { study. British } \\
\text { Journal of } \\
\text { Anaesthesia } 1966 \\
\text { 38. } 459 \text {. }\end{array}$ & Experimental & $\begin{array}{l}\text { An experiment } \\
\text { to demonstrate } \\
\text { the effect of } \\
\text { catheter suction } \\
\text { on tracheas of } \\
\text { kittens is } \\
\text { described. } \\
\text { Damage to the } \\
\text { trachea is } \\
\text { shown to } \\
\text { increase with } \\
\text { the suction } \\
\text { pressure applied } \\
\text { and it is } \\
\text { recommended } \\
\text { that pressures of } \\
10 \text { cm Hg } \\
\text { should not be } \\
\text { exceeded. }\end{array}$ & $\begin{array}{l}\text { Aspirations were } \\
\text { done } \\
\text { using negative } \\
\text { pressures of } 5,10,20 \\
\text { and } 30 \mathrm{~cm} \\
\mathrm{Hg} \text { respectively. ( } 50 \\
\text { to } 300 \mathrm{~mm} \mathrm{Hg} \text {.) }\end{array}$ & $\begin{array}{l}\text { In summary, it was } \\
\text { found that mucosal } \\
\text { ulceration occurred with } \\
\text { passage of the catheter } \\
\text { alone, and that the } \\
\text { severity of ulceration } \\
\text { varied directly with the } \\
\text { increase in negative } \\
\text { pressure. In clinical } \\
\text { practice, we find that } \\
\text { pressures of } 7 \\
\text { to } 10 \mathrm{~cm} \text { Hg are adequate } \\
\text { to remove the thickest } \\
\text { secretions, and higher } \\
\text { pressures are therefore } \\
\text { avoided. }\end{array}$ & $\begin{array}{l}\text { Kittens } \\
n=6 .\end{array}$ & $\begin{array}{l}\text { Plum and Dunning (1956) } \\
\text { showed that tracheal trauma } \\
\text { was minimized with their } \\
\text { "regulated" suction } \\
\text { technique. The present } \\
\text { experiment, employing this } \\
\text { method, showed that trauma } \\
\text { occurred with the catheter } \\
\text { alone and with suction at a } \\
\text { pressure as low as } 5 \mathrm{~cm} \mathrm{Hg} \text {. } \\
\text { Plum and Dunning } \\
\text { (1956) set their suction } \\
\text { machine at a pressure of } 20 \\
\text { cm Hg. (200 mm Hg) }\end{array}$ \\
\hline
\end{tabular}




\begin{tabular}{|c|c|c|c|c|c|c|}
\hline $\begin{array}{l}\text { Fell T, Cheney F W. } \\
\text { Prevention of } \\
\text { hypoxia during } \\
\text { endotracheal } \\
\text { suctioning. Ann } \\
\text { Surg July } 1971 \text { Vol } \\
174 \text { no.1. }\end{array}$ & $\begin{array}{l}\text { Qasi- } \\
\text { experimental }\end{array}$ & $\begin{array}{l}\text { To determine } \\
\text { the extent to } \\
\text { which } \mathrm{Pa} \mathrm{O} 2 \\
\text { decreased } \\
\text { during ET } \\
\text { suctioning in } \\
\text { patients with } \\
\text { respiratory } \\
\text { failure. }\end{array}$ & $\begin{array}{l}\text { Negative } 60 \mathrm{~mm} \mathrm{Hg} \\
\text { producing a flow of } \\
\text { 18litres/min. Through } \\
3.5 \mathrm{~mm} \text { OD catheter. } \\
\text { Comment.(must be an } \\
\text { unoccluded vacuum } \\
\text { flow ) }\end{array}$ & $\begin{array}{l}\text { Insufflation of five litres } \\
\text { of } 02 \text { down a } \\
\text { sidearm during } \\
\text { endotracheal suction } \\
\text { diminished the rate of } \\
\text { decline of Pao } 2 \text { during } \\
\text { suction of normal dog } \\
\text { lungs. In patients with } \\
\text { respiratory insufficiency } \\
\text { the insufflations of } 02 \\
\text { during suction did not } \\
\text { have any effect on the } \\
\text { decreased Pao2 seen } \\
\text { during endotracheal } \\
\text { suction. }\end{array}$ & $\begin{array}{l}\text { Initial } \\
\text { studies } \\
\text { were } \\
\text { performed } \\
\text { in five } \\
\text { adult } \\
\text { mongrel } \\
\text { dogs of } \\
\text { mean } \\
\text { weight of } \\
26 \\
\mathrm{Kg} .\end{array}$ & $\begin{array}{l}\text { Further alveolar collapse } \\
\text { from } \\
\text { the suction per se, which } \\
\text { would increase the amount } \\
\text { of shunt, may also have } \\
\text { occurred due to the forced } \\
\text { exhalation associated with } \\
\text { coughing and bucking. Due } \\
\text { to the overriding influence } \\
\text { of these factors, any } \\
\text { increase in alveolar Po2 } \\
\text { brought about by the } \\
\text { sidearm flow of oxygen was } \\
\text { not enough to influence the } \\
\text { Pao2 during suction. }\end{array}$ \\
\hline $\begin{array}{l}\text { Kuzenski Barbara. } \\
\text { Effects of negative } \\
\text { pressure on tracheo } \\
\text { bronchial trauma. } \\
\text { Nursing Research. } \\
\text { July August } 1978 \text {. } \\
\text { Vol } 27 \text { no } 4 \text {. }\end{array}$ & $\begin{array}{l}\text { Qasi- } \\
\text { experimental }\end{array}$ & $\begin{array}{l}\text { To test the } \\
\text { effect of } \\
\text { different } \\
\text { negative } \\
\text { pressures on } \\
\text { tracheo } \\
\text { bronchial } \\
\text { trauma in the } \\
\text { presence of } \\
\text { simulated } \\
\text { mucous. }\end{array}$ & $\begin{array}{l}\text { Negative pressures of } \\
100 \text { and } 200 \mathrm{~mm} \mathrm{Hg} . \\
\text { A size } 14 \text { fr catheter } \\
\text { and a } 7.5 \mathrm{ID} \\
\text { endotracheal tube. }\end{array}$ & $\begin{array}{l}\text { Tracheo bronchial } \\
\text { trauma occurred with } \\
\text { suctioning at negative } \\
\text { pressures of } 100 \text { and } 200 \\
\text { mm Hg. Results were } \\
\text { consistent with } \\
\text { postulates made by other } \\
\text { investigators in that the } \\
\text { extent of tracheo } \\
\text { bronchial trauma was } \\
\text { directly related to the } \\
\text { magnitude of the } \\
\text { negative pressure } \\
\text { applied. In addition } \\
\text { aspiration efficiency }\end{array}$ & $\begin{array}{l}2 \text { mongrel } \\
\text { dogs } 15 \\
\mathrm{Kg} .\end{array}$ & $\begin{array}{l}\text { An oft cited paper. "Since } \\
\text { mucous is secreted in } \\
\text { response to an irritating } \\
\text { stimulus in order to protect } \\
\text { tracheo bronchial tissue } \\
\text { from damage by the } \\
\text { stimulus." }\end{array}$ \\
\hline
\end{tabular}




\begin{tabular}{|c|c|c|c|c|c|c|}
\hline & & & & $\begin{array}{l}\text { proved to be the same } \\
\text { regardless of the negative } \\
\text { pressure used. } \\
\text { Suctioning at } 200 \mathrm{~mm} \\
\text { Hg. recovered } \\
\text { approximately the same } \\
\text { amount of mucous as } \\
\text { suctioning at } 100 \mathrm{~mm} \\
\mathrm{Hg} \text {. }\end{array}$ & & \\
\hline $\begin{array}{l}\text { Lander J F, Kwoka } \\
\text { M A, Chapman G A, } \\
\text { Brito M, Sackner M } \\
\text { A. Effects of } \\
\text { suctioning on muco- } \\
\text { cilliary transport. } \\
\text { CHEST } 198077 \text {; } \\
202 \text { - } 207 .\end{array}$ & $\begin{array}{l}\text { Quasi- } \\
\text { experimental }\end{array}$ & $\begin{array}{l}\text { We previously } \\
\text { have shown that } \\
\text { the mucosa of } \\
\text { the airway is } \\
\text { injured after } \\
\text { suctioning, but } \\
\text { the effect of this } \\
\text { damage on } \\
\text { mucus transport } \\
\text { has not been } \\
\text { systematically } \\
\text { investigated. } \\
\text { We measured } \\
\text { bronchial } \\
\text { mucus velocity } \\
\text { of } \\
\text { conscious sheep } \\
\text { after }\end{array}$ & $\begin{array}{l}\text { Vacuum neg } 100 \mathrm{~mm} \\
\text { Hg. }\end{array}$ & $\begin{array}{l}\text { We conclude that suction } \\
\text { catheters with tips } \\
\text { designed to minimise } \\
\text { mucosal contact are less } \\
\text { injurious to mucous } \\
\text { transport than } \\
\text { conventional end / side } \\
\text { hole suctioning catheters. }\end{array}$ & $\begin{array}{l}13 \text { female } \\
\text { sheep } 24 \text { to } \\
45 \mathrm{Kg} \text {. }\end{array}$ & $\begin{array}{l}\text { A description of how a } \\
\text { modified suction catheter } \\
\text { may influence air flow and } \\
\text { tendency to "grab" tissue } \\
\text { when suctioning initiated. } \\
\text { The "Aero-Flow "catheter } \\
\text { style catheter. }\end{array}$ \\
\hline
\end{tabular}




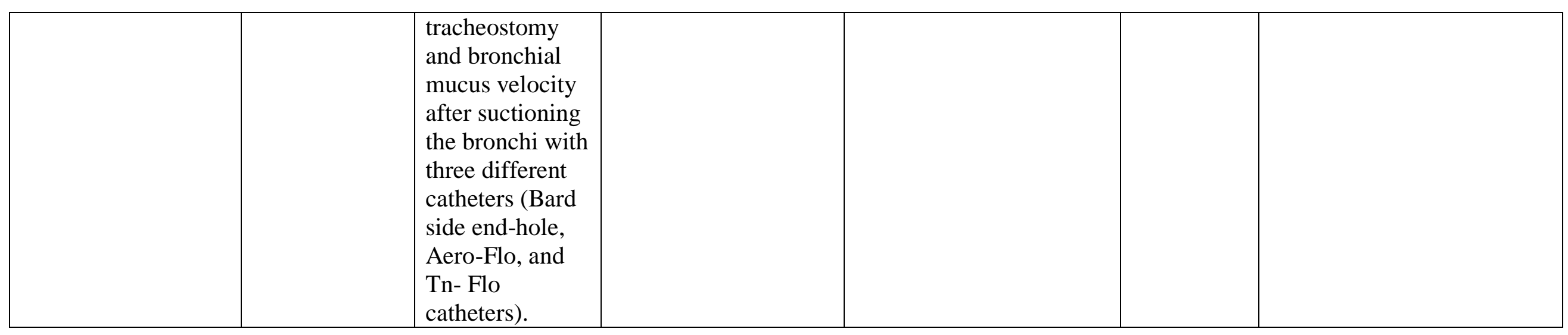




\begin{tabular}{|c|c|c|c|c|c|c|c|}
\hline $\begin{array}{l}\text { Czarnik R E, Stone } \\
\text { K S, Everhart C C, } \\
\text { Preusser B A. } \\
\text { Differential effects } \\
\text { of continuous versus } \\
\text { intermittent suction } \\
\text { on tracheal tissue. } \\
\text { Heart and Lung } \\
\text { March 1991 vol 20, } \\
\text { no 2; 144-151. }\end{array}$ & $\begin{array}{l}\text { quasi- } \\
\text { experimental }\end{array}$ & $\begin{array}{l}\text { The purpose of } \\
\text { this study was } \\
\text { to determine the } \\
\text { differential } \\
\text { effect of } \\
\text { continuous } \\
\text { versus } \\
\text { intermittent } \\
\text { application of } \\
\text { negative } \\
\text { pressure on } \\
\text { tracheal tissue } \\
\text { during } \\
\text { endotracheal } \\
\text { suctioning. }\end{array}$ & $\begin{array}{l}\text { Vacuum of } \\
\text { neg. } 200 \mathrm{~mm} \\
\text { Hg. creating a } \\
\text { flow of } 16 \\
\text { L/min through } \\
\text { a size } 14 \mathrm{Fr} \\
\text { catheter. } \\
\text { Inserted until } \\
\text { resistance } \\
\text { met... I.e. } \\
\text { deep. }\end{array}$ & \multicolumn{2}{|c|}{$\begin{array}{l}\text { Results indicate that both } \\
\text { continuous and intermittent } \\
\text { application of negative pressure } \\
\text { with endotracheal suctioning } \\
\text { produces significant damage to } \\
\text { tracheal tissue. Tracheal tissue } \\
\text { damage of the type found in this } \\
\text { study results in the reduction of } \\
\text { the normal muco-cilliary } \\
\text { clearing mechanism and the } \\
\text { production of additional } \\
\text { secretions. }\end{array}$} & $\begin{array}{l}12 \text { mongrel } \\
\text { dogs }\end{array}$ & $\begin{array}{l}\text { An animal model was } \\
\text { selected for this experiment } \\
\text { because post mortem } \\
\text { pathologic examination of } \\
\text { bronchial tissue was } \\
\text { necessary to compare the } \\
\text { differential effects of } \\
\text { continuous versus } \\
\text { intermittent suction on } \\
\text { bronchial tissue. Dogs were } \\
\text { chosen because previous } \\
\text { research on tracheal tissue } \\
\text { damage has been performed } \\
\text { in this animal model. }\end{array}$ \\
\hline $\begin{array}{l}\text { Almgren B, } \\
\text { Wickerts CJ } \\
\text { Heinonen E } \\
\text { Hogman M. Side } \\
\text { effects of } \\
\text { endotracheal suction } \\
\text { in pressure and } \\
\text { volume controlled } \\
\text { ventilation. CHEST }\end{array}$ & $\begin{array}{l}\text { quasi- } \\
\text { experimental }\end{array}$ & $\begin{array}{l}\text { Interventions: } \\
\text { The effects of } \\
\text { endotracheal } \\
\text { suction during } \\
\text { VCV and PCV } \\
\text { with tidal } \\
\text { volume (VT) of } \\
14 \mathrm{~mL} / \mathrm{kg} \text { were } \\
\text { compared. A }\end{array}$ & \multicolumn{2}{|c|}{$\begin{array}{l}\text { neg } 14 \mathrm{kPa} \text { with size } \\
12 \text { and } 14 \text { French } \\
\text { catheters. }\end{array}$} & $\begin{array}{l}\text { In conclusion ETS } \\
\text { causes lung collapse } \\
\text { leading to impaired gas } \\
\text { exchange, an effect that } \\
\text { is more severe and } \\
\text { persistent in pressure } \\
\text { control ventilation than } \\
\text { volume controlled } \\
\text { ventilation In conclusion. }\end{array}$ & 12 pigs. & \\
\hline
\end{tabular}




\begin{tabular}{|c|c|c|c|c|c|c|}
\hline $\begin{array}{l}20041251077 \text { - } \\
1080\end{array}$ & & $\begin{array}{l}\text { 60-mm inner- } \\
\text { diameter } \\
\text { endotracheal } \\
\text { tube was used. }\end{array}$ & & $\begin{array}{l}\text { Our study provides } \\
\text { further evidence that } \\
\text { endotracheal suction can } \\
\text { cause lung collapse. }\end{array}$ & & \\
\hline $\begin{array}{l}\text { Almgren B. } \\
\text { Endotracheal } \\
\text { suction a reopened } \\
\text { problem. } 2005 \\
\text { Digital } \\
\text { comprehensive } \\
\text { summaries of } \\
\text { Uppsala } \\
\text { dissertations from } \\
\text { the faculty of } \\
\text { Medicine } 11 . \text { issn } \\
1651-6206\end{array}$ & $\begin{array}{l}\text { quasi- } \\
\text { experimental }\end{array}$ & $\begin{array}{l}\text { The aim of this } \\
\text { study was to } \\
\text { investigate the } \\
\text { effects of } \\
\text { endotracheal } \\
\text { suction during } \\
\text { different } \\
\text { ventilator } \\
\text { settings and by } \\
\text { different suction } \\
\text { methods. }\end{array}$ & $\begin{array}{l}\text { Negative } 15 \mathrm{kPa} \text { and } \\
20 \mathrm{kPa} \text {. size } 12 \text { and } \\
14 \mathrm{fr} \text { catheters but } \\
\text { size } 6 \text { ID ETT. }\end{array}$ & $\begin{array}{l}\text { In conclusion open } \\
\text { endotracheal suction } \\
\text { causes impairment in gas } \\
\text { exchange and lung } \\
\text { mechanics and more so } \\
\text { in pressure controlled } \\
\text { than in volume } \\
\text { controlled mode. }\end{array}$ & $\begin{array}{l}\text { pigs } 17 \text { to } \\
35 \mathrm{Kg} \text {. }\end{array}$ & \\
\hline $\begin{array}{l}\text { Kasim I, Gulyas M, } \\
\text { Amlgren B, } \\
\text { Hogman. A } \\
\text { recruitment } \\
\text { manoeuvre directly } \\
\text { after endotracheal } \\
\text { suction improves } \\
\text { lung function; An } \\
\text { experimental study } \\
\text { in pigs..Uppsala }\end{array}$ & $\begin{array}{l}\text { quasi } \\
\text { experimental }\end{array}$ & $\begin{array}{l}\text { Atelectasis } \\
\text { occurs after a } \\
\text { well performed } \\
\text { endotracheal } \\
\text { suction. Clinical } \\
\text { studies have } \\
\text { shown that } \\
\text { recruitment } \\
\text { manoeuvres } \\
\text { added after }\end{array}$ & $\begin{array}{l}\text { neg } 14 \mathrm{kPa} \text {. size } 14 \\
\text { Fr. Catheter and size } \\
\text { 6 ETT. }\end{array}$ & $\begin{array}{l}\text { Atelectasis created by } \\
\text { endotracheal suction can } \\
\text { be opened by inflating } \\
\text { the lung for a short } \\
\text { duration with low } \\
\text { pressure without over } \\
\text { distension, immediately } \\
\text { after suction. }\end{array}$ & $\begin{array}{l}12 \text { pigs } 28 \\
\text { to } 35 \mathrm{Kg} \text {. }\end{array}$ & $\begin{array}{l}\text { Suctioning using the size } 14 \\
\text { catheter through a size } 6 \\
\text { ETT at A vacuum of } 14 \mathrm{kPa} \\
\text { reduces Vt from } 345 \mathrm{ml} \text { to } \\
247 \mathrm{ml} \text {. }\end{array}$ \\
\hline
\end{tabular}




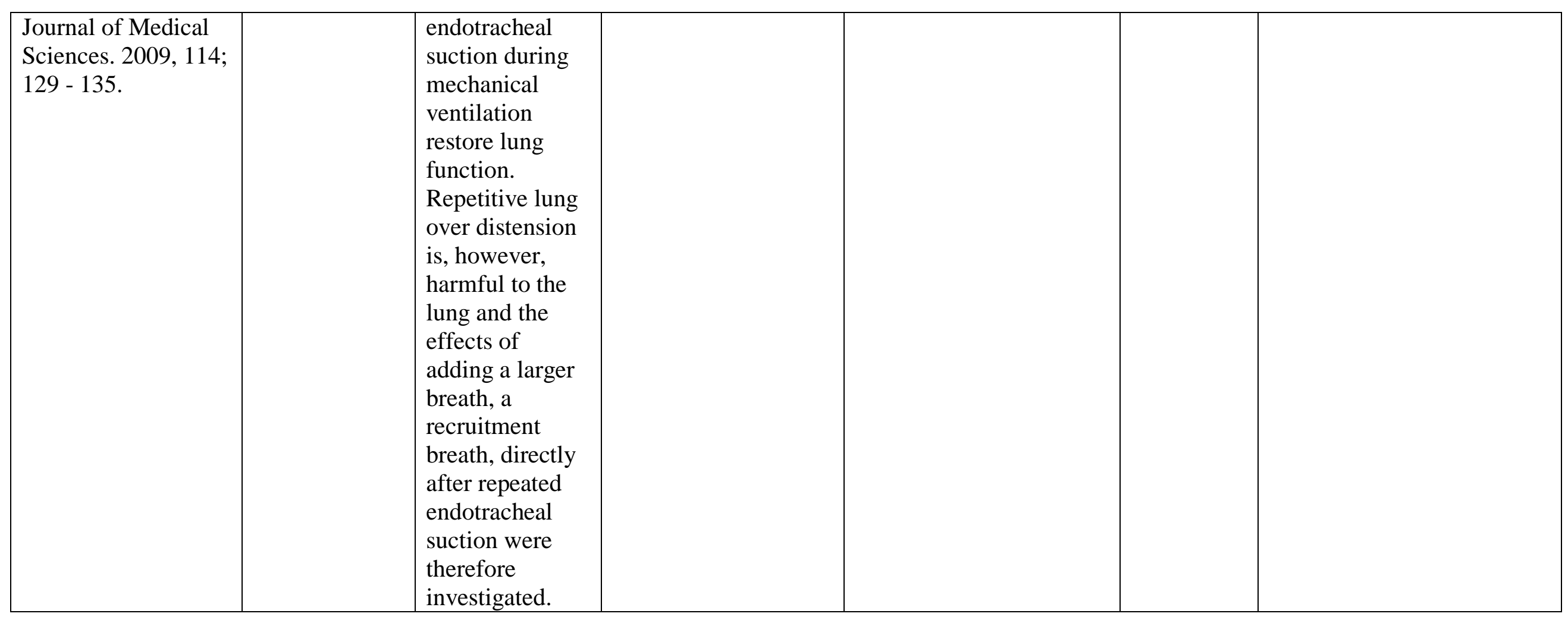




\begin{tabular}{|c|c|c|c|c|c|c|}
\hline $\begin{array}{l}\text { Copnell B, Dargaill } \\
\text { P. Ryan E, et al. The } \\
\text { effect of suction } \\
\text { method, catheter } \\
\text { size and suction } \\
\text { pressure on lung } \\
\text { volume changes } \\
\text { during endotracheal } \\
\text { suction in piglets. } \\
\text { Pediatric Research } \\
\text { 2009. vol. } 66 \text { No. 4; } \\
\text { 405-410. }\end{array}$ & $\begin{array}{c}\text { quasi } \\
\text { experimental }\end{array}$ & $\begin{array}{l}\text { We aimed to } \\
\text { identify the } \\
\text { effect of suction } \\
\text { pressure and } \\
\text { catheter size on } \\
\text { change in lung } \\
\text { volume during } \\
\text { open and closed } \\
\text { endotracheal } \\
\text { suction }\end{array}$ & $\begin{array}{l}\text { Vacuum pressures of } \\
80,140 \text { and } 200 \mathrm{~mm} \\
\text { Hg. Through size } 6, \\
7, \text { and } 8 \text { Fr catheters. } \\
\text { Pigs were intubated } \\
\text { with a size } 4 \text { ID ETT. }\end{array}$ & $\begin{array}{l}\text { Overall, open suction } \\
\text { resulted in greater lung } \\
\text { volume loss during and } \\
\text { at } 60 \text { sec post suction } \\
\text { than either closed } \\
\text { method (p<0.001). With } \\
\text { an } 8 \text { Fr catheter and } \\
\text { suction pressures of } 140 \\
\text { or } 200 \text { mm Hg. Volume } \\
\text { loss was equivalent with } \\
\text { open and closed suction. } \\
\text { Lung volume changes } \\
\text { are influenced by } \\
\text { catheter size and suction } \\
\text { pressure, as well as } \\
\text { suction method. With } \\
\text { commonly used suction } \\
\text { pressures and catheter } \\
\text { sizes, closed suction has } \\
\text { no advantage in } \\
\text { preventing loss of } \\
\text { volume in this animal } \\
\text { model. }\end{array}$ & $\begin{array}{l}\text { It was not } \\
\text { feasible to } \\
\text { conduct the } \\
\text { study in } \\
\text { human } \\
\text { infants, as } \\
\text { the } \\
\text { protocol } \\
\text { required } \\
\text { multiple } \\
\text { episodes of } \\
\text { suction in a } \\
\text { short time } \\
\text { frame, } \\
\text { together } \\
\text { with } \\
\text { repeated } \\
\text { alveolar } \\
\text { recruitment } \\
\text { and } \\
\text { derecruitm } \\
\text { ent and } \\
\text { thus an } \\
\text { animal } \\
\text { model was } \\
\text { used. } 12 \\
\text { two week } \\
\text { old piglets. }\end{array}$ & $\begin{array}{l}\text { This study appears to } \\
\text { demonstrate that once } \\
\text { vacuum pressure reached } \\
\text { 140mm Hg there was no } \\
\text { benefit from closed suction } \\
\text { over open remembering that } \\
\text { open resulted in the greatest } \\
\text { loss of volume overall. This } \\
\text { would seem to highlight the } \\
\text { importance of taking } \\
\text { vacuum / driving pressure } \\
\text { into account as well as } \\
\text { selection of catheter size. A } \\
\text { size } 8 \text { Fr catheter has an } \\
\text { external diameter of } \\
\text { 2.66mm which is more than } \\
\text { half the internal diameter of } \\
\text { the size 4mm internal } \\
\text { diameter ETT. }\end{array}$ \\
\hline
\end{tabular}




\begin{tabular}{|c|c|c|c|c|c|c|}
\hline $\begin{array}{l}\text { Tingay D G, } \\
\text { Copnell B, Grant C } \\
\text { A, Dargaville P A, } \\
\text { Dunster K R, } \\
\text { Schibler. The effect } \\
\text { of endotracheal } \\
\text { suction on regional } \\
\text { tidal ventilation and } \\
\text { end expiratory } \\
\text { volume. Intensive } \\
\text { Care Medicine. } \\
\text { 2010. 36. 888-896. }\end{array}$ & $\begin{array}{l}\text { quasi } \\
\text { experimental }\end{array}$ & $\begin{array}{l}\text { To examine the } \\
\text { impact of } \\
\text { different } \\
\text { endotracheal } \\
\text { tube (ETT) } \\
\text { suction } \\
\text { techniques on } \\
\text { regional end } \\
\text { expiratory lung } \\
\text { volume (Vt) in } \\
\text { an animal } \\
\text { model of } \\
\text { surfactant- } \\
\text { deficient lung } \\
\text { injury. }\end{array}$ & $\begin{array}{l}\text { Neg } 140 \mathrm{~mm} \mathrm{Hg.} \\
\text { Catheter size } 5 \text { and } 8 \\
\text { Fr. (1.7 and } 2.7 \mathrm{~mm}) . \\
\text { Size } 4 \text { ID }(4 \mathrm{~mm} \\
\text { internal diameter }) \\
\text { ETT tubes. }\end{array}$ & $\begin{array}{l}\text { ETT suction causes } \\
\text { transient loss of EELV } \\
\text { (end expired lung } \\
\text { volume) and Vt (tidal } \\
\text { volume) throughout the } \\
\text { lung. Catheter size exerts } \\
\text { a greater influence than } \\
\text { suction method, with } \\
\text { closed suction only } \\
\text { protecting against } \\
\text { derecruitment when a } \\
\text { small catheter is used, } \\
\text { especially in the non- } \\
\text { dependent lung. }\end{array}$ & $\begin{array}{l}2 \text { week old } \\
\text { piglets } \\
n=6 .\end{array}$ & $\begin{array}{l}\text { While even with closed } \\
\text { suction a large catheter in a } \\
\text { small ETT, at a high } \\
\text { vacuum pressure, will } \\
\text { collapse your lung. Open } \\
\text { suction will do it more so. }\end{array}$ \\
\hline $\begin{array}{l}\text { Caramez M P, } \\
\text { Schettino G, } \\
\text { Suchodolski K, et al. } \\
\text { The impact of } \\
\text { endotracheal } \\
\text { suctioning on gas } \\
\text { exchange and } \\
\text { haemodynamics } \\
\text { during lung } \\
\text { protective } \\
\text { ventilation in acute } \\
\text { respiratory distress } \\
\text { syndrome. } \\
\text { Respiratory care }\end{array}$ & $\begin{array}{l}\text { quasi } \\
\text { experimental }\end{array}$ & $\begin{array}{l}\text { To evaluate he } \\
\text { respiratory and } \\
\text { haemodynamics } \\
\text { effects of open } \\
\text { suction versus } \\
\text { closed } \\
\text { suctioning } \\
\text { during pressure } \\
\text { control and } \\
\text { volume control } \\
\text { ventilation } \\
\text { using a lung } \\
\text { protective } \\
\text { ventilation } \\
\text { strategy in an }\end{array}$ & $\begin{array}{l}\text { Neg pressure } 100 \mathrm{~mm} \\
\mathrm{Hg} \text {. The size } 9 \text { ETT } \\
\text { tube was suctioned } \\
\text { with a } 14 \mathrm{FR} 4.7 \mathrm{~mm} \text { ) } \\
\text { suction catheter. }\end{array}$ & $\begin{array}{l}\mathrm{PaO} 2 \text { / Fi O2 was better } \\
\text { maintained during closed } \\
\text { suctioning with both } \\
\text { volume control and } \\
\text { pressure control modes } \\
\text { during lung protective } \\
\text { ventilation for ARDS as } \\
\text { compared with open } \\
\text { suctioning and shunt } \\
\text { fraction post suctioning } \\
\text { changed least with } \\
\text { pressure control. }\end{array}$ & $\begin{array}{l}8 \text { Dorset } \\
\text { sheep } 25 \text { to } \\
35 \mathrm{Kg} . \\
\text { Intubated } \\
\text { with a size } \\
9 \text { ID ETT } \\
\text { (large). }\end{array}$ & $\begin{array}{l}\text { Here is a combination of } \\
\text { low suction /vacuum with a } \\
\text { large size ETT . Still } \\
\text { producing measurable } \\
\text { results with regard to lung } \\
\text { volume and hemodynamics. }\end{array}$ \\
\hline
\end{tabular}


May 2006 vol 51

no5 p.497-502

animal model of acute

respiratory

distress

syndrome. 


\title{
APPENDIX V. Included Studies
}

\author{
Studies Reviewed ( $\mathrm{n}=30$ ). In Chronological order;
}

\begin{tabular}{|c|c|}
\hline Study & $\begin{array}{l}\text { Plum, F. \& Dunning, M. Techniques for minimizing trauma to the tracheobronchial tree after } \\
\text { tracheotomy. The New England Journal of Medicine 254, 193-200 (1956). }\end{array}$ \\
\hline Method & Quasi Experimental \\
\hline Subjects & $\begin{array}{l}8 \text { patients who died eighteen to ninety six hours after tracheostomy were examined post } \\
\text { mortem. } 8 \text { patients followed after introduction of regulated pressure regime. } 1 \text { autopsy post } \\
\text { mortem }\end{array}$ \\
\hline Approach & $\begin{array}{l}\text { A method of tracheobronchial cleansing was devised in an effort to reduce tracheobronchial } \\
\text { trauma. Suction was briefly and intermittently applied so as to avoid hypoxia; vacuum } \\
\text { pressures were carefully controlled to minimize membrane damage and gentle guiding and } \\
\text { manipulation of catheters was emphasised. Experimentally, this regulated pressure method was } \\
\text { found to cause less tracheobronchial damage than the usual techniques of tracheal cleansing. } \\
\text { The intensity of post-tracheostomy tracheobrochitis and the duration of hemorrhagic } \\
\text { tracheobronchial secretions were reduced when this technique was applied to human patients. }\end{array}$ \\
\hline $\begin{array}{l}\text { Vacuum } \\
\text { Pressure }\end{array}$ & $\begin{array}{l}\text { Deep suctioning No } 12 \text { or } 14 \text { blunt tipped rubber catheters and pressures of } 250 \text { to } 380 \text { and } \\
\text { sometimes } 500 \mathrm{mmHg} \text {. Vs } .200 \mathrm{~mm} \mathrm{Hg} \text {. using a "y" suction catheter in the regulated suction } \\
\text { group. }\end{array}$ \\
\hline Finding & $\begin{array}{l}\text { "It is our impression that after tracheotomy, patients have cleaner tracheobronchial aspirations, } \\
\text { less bloody aspirates and less severe tracheal reactions when treated with the techniques } \\
\text { recommended. The pathological changes in patients suctioned by the observed method } \\
\text { emphasized the need for a more gentle approach; both the bedside observations and the results } \\
\text { of the experiments indicate that the regulated-pressure method of cleansing the } \\
\text { tracheobronchial tree is superior to those previously in general use." }\end{array}$ \\
\hline $\begin{array}{l}\text { Reviewer } \\
\text { comment }\end{array}$ & $\begin{array}{l}\text { Foreshadowed the introduction of the "Y" suction catheter and the regimen of insert then draw } \\
\text { back } 1 \text { or } 2 \mathrm{~cm} \text { before application of vacuum. }\end{array}$ \\
\hline
\end{tabular}




\begin{tabular}{|c|c|}
\hline Study 2. & $\begin{array}{l}\text { Egbert, L.D., Laver, M.B. \& Bendixen, H.H. Intermittent deep breaths and Compliance } \\
\text { during anesthesia in man. Anesthesiology 24, 58-60 (1963). }\end{array}$ \\
\hline Method & Quasi experimental \\
\hline Subjects & 32 patients; 19 subject to ET suctioning. \\
\hline Approach & $\begin{array}{l}\text { In } 19 \text { patients we inserted a suction catheter size } 12 \mathrm{Fr} \text { into the endotracheal tube and } \\
\text { aspirated for } 5 \text { seconds. Each patient served as his own control. Differences were tested for } \\
\text { statistical significance using the } \mathrm{t} \text { test. }\end{array}$ \\
\hline $\begin{array}{l}\text { Vacuum } \\
\text { Pressure }\end{array}$ & Suction flow rate of 15 to 20 Litres per minute through a size 12 Fr catheter. \\
\hline Finding & $\begin{array}{l}\text { Expanding the lung improves lung compliance by reopening atelectatic alveoli. Aspirating } \\
\text { the trachea would improve lung compliance if secretions obstructing the airways are } \\
\text { removed; otherwise, aspirating air from the trachea will lower lung compliance. }\end{array}$ \\
\hline $\begin{array}{l}\text { Reviewer } \\
\text { Comment }\end{array}$ & Informs the outcome of interest with regard to lung volume loss from suctioning. \\
\hline
\end{tabular}




\begin{tabular}{|c|c|}
\hline Study 3 & $\begin{array}{l}\text { Urban, B.J. \& Weitzner, S.W. Avoidance of hypoxemia during endotracheal suction. } \\
\text { Anesthesiology } 31,473-475 \text { (1969). }\end{array}$ \\
\hline Method & Quasi Experimental. \\
\hline Subjects & Seven male patients requiring mechanical ventilation \\
\hline Approach & $\begin{array}{l}\text { In theory removal of intrathoracic gas during suctioning could be offset by an increased } \\
\text { inspiratory flow. This is easily accomplished by increasing the inspiratory minute volume, } \\
\text { thus using the lung as a reservoir for gas removal by continuous suction. }\end{array}$ \\
\hline $\begin{array}{l}\text { Vacuum } \\
\text { Pressure }\end{array}$ & "Conventional" suction developing flow rates of 13 to 18 litres per minute. \\
\hline Finding & $\begin{array}{l}\text { Oxygenation may be preserved with a closed suction system and volume guaranteed } \\
\text { ventilation. }\end{array}$ \\
\hline $\begin{array}{l}\text { Reviewer } \\
\text { Comment }\end{array}$ & $\begin{array}{l}\text { Flow rates described will correspond to a vacuum setting of some } 100 \mathrm{~mm} \mathrm{Hg} \text {. This study } \\
\text { foresees the closed suction system where the ventilator may cause ingress of oxygen to offset } \\
\text { the flow removed by suctioning thereby maintaining lung volume. }\end{array}$ \\
\hline
\end{tabular}

\begin{tabular}{|l|l|}
\hline Study 4 & $\begin{array}{l}\text { Brandstater, B. Atelectasis following tracheal suction in infants. Anesthesiology, 468-473 } \\
(1969) .\end{array}$ \\
\hline Method & Quasi-experimental \\
\hline Subjects & 6 Newborn 7 to 34 days with healthy lungs. \\
\hline Approach & $\begin{array}{l}\text { The studies reported here were designed to show the extent of atelectasis, as presented by } \\
\text { compliance change, occurring in the lungs of infants subjected to transbronchial suction and } \\
\text { the subsequent behaviour of collapsed areas. }\end{array}$ \\
\hline $\begin{array}{l}\text { Vacuum } \\
\text { Pressure }\end{array}$ & $\begin{array}{l}\text { P=<46 cm H2O during suctioning (probably not and occluded vacuum pressure but read off } \\
\text { a manometer during suctioning). (33mm Hg.) }\end{array}$ \\
\hline Finding & $\begin{array}{l}\text { We have failed to find a convincing mechanism for compliance fall other than collapse of air } \\
\text { spaces and believe that the changes seen in our subjects were a quantitative index of } \\
\text { atelectasis. }\end{array}$ \\
\hline $\begin{array}{l}\text { Reviewer } \\
\text { Comment }\end{array}$ & $\begin{array}{l}\text { Describing the possibility of lung volume loss of up to 50\% after deep suctioning and } \\
\text { observing that quite high reopening pressures are needed to restore collapsed areas the } \\
\text { authors hypothesise that suctioning may be doing as much harm as good. }\end{array}$ \\
\hline
\end{tabular}




\begin{tabular}{|c|c|}
\hline Study 5 & $\begin{array}{l}\text { Boutros, A.R. Arterial blood oxygenation before and after endotracheal suctioning in the } \\
\text { apnoeic patient. Anesthesiology } 32,114-118 \text { (1970). }\end{array}$ \\
\hline Method & Quasi experimental \\
\hline Subjects & 22 patients scheduled for operative procedures without known lung disease. \\
\hline Approach & $\begin{array}{l}\text { Arterial blood gas measurements at } 30,60,120 \text { and } 180 \text { seconds after suctioning with size } 16 \\
\text { catheters and full occlusion. }\end{array}$ \\
\hline $\begin{array}{l}\text { Vacuum } \\
\text { Pressure }\end{array}$ & 20 inches of mercury or about $500 \mathrm{~mm} \mathrm{Hg}$. was described. \\
\hline Finding & $\begin{array}{l}\text { The significant difference between the effects of apnoea and the effects of suction in all } \\
\text { groups in this study indicates that varying degrees of atelectasis probably occurred, } \\
\text { presumably as a result of production of negative pressure in the lungs during suction. }\end{array}$ \\
\hline $\begin{array}{l}\text { Reviewer } \\
\text { Comment }\end{array}$ & $\begin{array}{l}\text { One of earlier studies observing a loss of functional lung from using a catheter which is } \\
\text { larger than half the internal diameter of the tracheal Tube and high vacuum pressure. }\end{array}$ \\
\hline
\end{tabular}

\begin{tabular}{|l|l|}
\hline Study 6 & $\begin{array}{l}\text { Fell, T. \& Cheney, F.W. Prevention of hypoxia during endotracheal suctioning. Ann. Surg. } \\
174,24-28(1972) .\end{array}$ \\
\hline Method & Quasi experimental \\
\hline Subjects & 26 patients 24 to 75 years of age requiring respiratory support. \\
\hline Approach & $\begin{array}{l}\text { To determine the extent to which PaO2 decreased during endotracheal suction in patients } \\
\text { with respiratory failure. }\end{array}$ \\
\hline $\begin{array}{l}\text { Vacuum } \\
\text { Pressure }\end{array}$ & $\begin{array}{l}\text { Flow of } 16 \text { Litres a minute and a negative pressure of } 60 \text { mm Hg. } \\
\text { Finding }\end{array}$ \\
\hline $\begin{array}{l}\text { Reviewer } \\
\text { Comment }\end{array}$ & $\begin{array}{l}\text { Hyperoxygenation with } 100 \text { per cent oxygen may itself result in atelectasis but this is } \\
\text { disguised as the circulating blood oxygen level is boosted. }\end{array}$ \\
\hline
\end{tabular}




\begin{tabular}{|l|l|}
\hline Study 7 & $\begin{array}{l}\text { Petersen, G.M., Pierson, D.J. \& Hunter, P.M. Arterial oxygen saturation during } \\
\text { nasotracheal suctioning. Chest 76, 283-287 (1979). }\end{array}$ \\
\hline Method & Quasi experimental \\
\hline Subjects & 31 Patients for whom naso-tracheal suction had been prescribed from various specialties \\
\hline Approach & $\begin{array}{l}\text { This study demonstrates the significant arterial desaturation can occur during nasotracheal } \\
\text { suctioning. }\end{array}$ \\
\hline $\begin{array}{l}\text { Vacuum } \\
\text { Pressure }\end{array}$ & 100 to $120 \mathrm{~mm}$ Hg. Through a size 14 Fr suction catheter. \\
\hline Finding & Desaturation during nasotracheal suctioning may be of a potentially serious magnitude \\
\hline $\begin{array}{l}\text { Reviewer } \\
\text { Comment }\end{array}$ & $\begin{array}{l}\text { Although not strictly endotracheal suctioning it is an interesting review of the effects of } \\
\text { regulated suction / vacuum pressure within the airway. }\end{array}$ \\
\hline
\end{tabular}

\begin{tabular}{|c|c|}
\hline Study 8 & $\begin{array}{l}\text { Brown, S.E., Stansbury, D.W., Merrill, E.J., Linden, G.S. \& Light, R.W. Prevention of } \\
\text { suctioning - related arterial oxygen desaturation. Comparison of off ventilator and on } \\
\text { ventilator suctioning. Chest } 83,621-627 \text { (1983). }\end{array}$ \\
\hline Method & Quasi experimental. \\
\hline Subjects & 22 patients with acute lung injury and underlying respiratory disease. \\
\hline Approach & $\begin{array}{l}\text { The purpose of this study was to determine the frequency and severity of arterial desaturation } \\
\text { during and after endotracheal suctioning in a group of ventilator dependent patients with acute } \\
\text { respiratory failure. }\end{array}$ \\
\hline $\begin{array}{l}\text { Vacuum } \\
\text { Pressure }\end{array}$ & $\begin{array}{l}80 \mathrm{~mm} \mathrm{Hg} \text { free flow through a size } 14 \mathrm{Fr} \text { catheter developing a flow rate of } 20 \text { litres / min. } \\
\text { (about } 100 \mathrm{~mm} \mathrm{Hg} \text { occlusion Pressure). }\end{array}$ \\
\hline Finding & $\begin{array}{l}\text { We conclude that the suctioning related desaturation which occurred in our patients can be } \\
\text { effectively minimised either by administering six ventilator } \mathrm{FiO} 2=1.0 \text { breaths before and } \\
\text { after each pass of the suction catheter, or by suctioning through an adaptor while the patient } \\
\text { remains attached to the ventilator. }\end{array}$ \\
\hline $\begin{array}{l}\text { Reviewer } \\
\text { Comment }\end{array}$ & $\begin{array}{l}\text { Again the administration of } \mathrm{Fi} \mathrm{O} 2 \text { of } 100 \% \text { is applied to reduce the fall in observed } \\
\text { circulating arterial oxygen content. }\end{array}$ \\
\hline
\end{tabular}




\begin{tabular}{|c|c|}
\hline Study 9 & $\begin{array}{l}\text { Baun, M.M., Frantz, R.A. \& Lindsay, A.M. Physiological determinants of a clinically } \\
\text { successful method of endotracheal suction. Western Journal of Nursing Research 6, 213-228 } \\
\text { (1984). }\end{array}$ \\
\hline Method & Quasi experimental. \\
\hline Subjects & 8 Subjects, (5 men and 3 women) \\
\hline Approach & $\begin{array}{l}\text { Investigating the correlation between the magnitude of hemodynamic and respiratory changes } \\
\text { during endotracheal aspiration and their baseline status prior to aspiration. To determine if a } \\
\text { standardised length of preoxygenation time prevents undesired changes in cardio-respiratory } \\
\text { variables. }\end{array}$ \\
\hline $\begin{array}{l}\text { Vacuum } \\
\text { Pressure }\end{array}$ & 14 Fr catheters and "wall suction" Flow rate of 17 to 30 litres/ min. described. \\
\hline Finding & $\begin{array}{l}\text { Even brief subatmospheric pressures as those developed by a large suction catheter in a } \\
\text { narrow ETT can cause a decrease in compliance (lung volume) and an increase in } \\
\text { cardio=pulmonary shunting. }\end{array}$ \\
\hline $\begin{array}{l}\text { Reviewer } \\
\text { Comment }\end{array}$ & $\begin{array}{l}\text { Contains a good summary of the physiological outcome related to negative intrapulmonary } \\
\text { pressure and loss of lung volume from suctioning in the discussion. }\end{array}$ \\
\hline
\end{tabular}

\begin{tabular}{|c|c|}
\hline Study 10 & $\begin{array}{l}\text { Walsh, J.M., Vanderwarf, C., Hoscheit, D. \& Fahey, P.J. Unsuspected hemodynamic } \\
\text { alterations during endotracheal suctioning. Chest 95, 162-165 (1989). }\end{array}$ \\
\hline Method & Observational study. \\
\hline Subjects & 10 acutely ill medical patients requiring intubation and positive pressure ventilation \\
\hline Approach & $\begin{array}{l}\text { To study the alterations in } \mathrm{CO}, \mathrm{Vo} 2 \mathrm{SaO} 2 \text { and the resulting effect on } \mathrm{SvO} 2 \text { during } \\
\text { endotracheal suctioning. }\end{array}$ \\
\hline $\begin{array}{l}\text { Vacuum } \\
\text { Pressure }\end{array}$ & $120 \mathrm{~mm} \mathrm{Hg}$ producing a flow of $20 \mathrm{~L} / \mathrm{min}$. \\
\hline Finding & $\begin{array}{l}\text { ETS produced a significant decrease in } \mathrm{SvO} 2 \text { which was predominately due to an increased } \\
\mathrm{VO} 2 \text { accompanied by an inadequate rise or even fall in cardiac output. }\end{array}$ \\
\hline $\begin{array}{l}\text { Reviewer } \\
\text { Comment }\end{array}$ & $\begin{array}{l}\text { Using the most commonly recommended levels of vacuum haemodynamic and ventilatory } \\
\text { effects are noted. Using a more sensitive measure than arterial oxygen saturation. }\end{array}$ \\
\hline
\end{tabular}




\begin{tabular}{|l|l|}
\hline Study 11 & $\begin{array}{l}\text { Kerim, E., Yatsiv, I. \& Goitein, K.J. Effect of endotracheal suctioning on blood gasses in } \\
\text { children. Intensive Care Medicine 16, 95-99 (1990). }\end{array}$ \\
\hline Method & Quasi-experimental. \\
\hline Subjects & 25 consecutive patients aged 1 day to 10 years. 97 episodes of suctioning were examined. \\
\hline Approach & $\begin{array}{l}\text { The study investigated the effect of suctioning on ABG in children and the efficacy of three } \\
\text { therapeutic methods to prevent the fall in Pa O2 during and after suctioning. }\end{array}$ \\
\hline $\begin{array}{l}\text { Vacuum } \\
\text { Pressure }\end{array}$ & $\begin{array}{l}\text { "standard wall suction" with catheter advanced until resistance met and withdrawn 2cm. () } \\
\text { Finding } \\
\text { can be prevented by preoxygenation. We assume that microatelectasis occurs during } \\
\text { suctioning and is reversed during hyperinflation }\end{array}$ \\
\hline $\begin{array}{l}\text { Reviewer } \\
\text { Comment }\end{array}$ & $\begin{array}{l}\text { Observing that increasing the circulating blood oxygen level can offset the fall induced by } \\
\text { suction induced atelectasis. Standard wall suction may or may not include a regulator the } \\
\text { practice in Israel is unknown but may follow US guidelines. }\end{array}$ \\
\hline
\end{tabular}

\begin{tabular}{|l|l|}
\hline Study 12 & $\begin{array}{l}\text { Stone, K., Bell, S. \& Preusser, B. The effect of repeated endotracheal suctioning on arterial } \\
\text { blood pressure. Applied Nursing Research 4, 152-164 (1991). }\end{array}$ \\
\hline Method & Quasi experimental. \\
\hline Subjects & "A convenience sample" 34 patients. Two large USA mid-western hospitals. \\
\hline Approach & $\begin{array}{l}\text { The purpose of this study was to examine the effects of three hyperinflation suction } \\
\text { sequences on mean arterial pressure. }\end{array}$ \\
\hline $\begin{array}{l}\text { Vacuum } \\
\text { Pressure }\end{array}$ & $\begin{array}{l}\text { A flow of 16 L / min through a size 14Fr catheter. (presumably with a suction regulator) } \\
\text { Finding }\end{array}$ \\
$\begin{array}{l}\text { The results indicate both lung hyperinflation and suction sequences significantly increased } \\
\text { be limited to only those necessary to maintain patency. }\end{array}$ \\
\hline $\begin{array}{l}\text { Reviewer } \\
\text { Comment }\end{array}$ & $\begin{array}{l}\text { Describes haemodynamic changes occurring with suction sequences and hyperinflation as } \\
\text { significant and cumulative. Even though a regulated suction flow of 16 Litres per minute is } \\
\text { reported through a size 14 Fr (4.7mm) catheter. }\end{array}$ \\
\hline
\end{tabular}




\begin{tabular}{|l|l|}
\hline Study 13 & $\begin{array}{l}\text { Boothroyd, A.E., Murthy, B.V.S., Darbyshire, A. \& Petros, A.J. Endotracheal suctioning } \\
\text { causes right upper lobe collapse in intubated children. Acta Paediatrica 85, 1422 - 1425 } \\
(1996) .\end{array}$ \\
\hline Method & Prospective audit, repeated after 3 months. \\
\hline Approach & $\begin{array}{l}\text { Pre regulation; } \mathrm{n}=102 \text { and post n=60. } \\
\text { hypothesized that that deep suctioning and uncontrolled negative pressures during } \\
\text { endotracheal tube suctioning were significant contributing factors. }\end{array}$ \\
\hline $\begin{array}{l}\text { Vacuum } \\
\text { Pressure }\end{array}$ & $\begin{array}{l}\text { Unregulated deep, until resistance met, suction Vs regulated suction < 165 cm H2O and } \\
\text { measured length of catheter insertion (120mm Hg, })\end{array}$ \\
\hline Finding & $\begin{array}{l}\text { We conclude that high negative pressure and deep suctioning causes right upper lobe collapse } \\
\text { in children. Any lobar collapse not only prolongs the child's stay in the intensive care unit but } \\
\text { can be associated with further morbidity which may have serious implications. By improving } \\
\text { suctioning techniques this morbidity can be significantly reduced. }\end{array}$ \\
\hline $\begin{array}{l}\text { Reviewer } \\
\text { Comment }\end{array}$ & $\begin{array}{l}\text { An interesting example of a clinical finding being observed and corrected by the } \\
\text { implementation of a regulated method of endotracheal suctioning. }\end{array}$ \\
\hline
\end{tabular}

\begin{tabular}{|l|l|}
\hline Study 14 & $\begin{array}{l}\text { Guglielminotti, J., Desmonts, J.-M. \& Dureuil, B. Effects of tracheal suctioning on respiratory } \\
\text { resistances in mechanically ventilated patients. Chest 113, 1135-1338 (1998). }\end{array}$ \\
\hline Method & Randomised crossover study. \\
\hline Subjects & 13 ICU patients mechanically ventilated various conditions. \\
\hline Approach & $\begin{array}{l}\text { Approach: objective; to evaluate the effect of tracheal suctioning on respiratory resistances in } \\
\text { sedated critical care patients receiving mechanical ventilation. }\end{array}$ \\
\hline Pressure & $\begin{array}{l}\text { Negative pressure -80 cm H2O or } 60 \text { mm Hg. Using size 14 Fr. Catheter inserted until } \\
\text { resistance felt. }\end{array}$ \\
\hline Finding & $\begin{array}{l}\text { Tracheal suction produces only a transient broncho-constrictor response, but thereafter does } \\
\text { not reduce respiratory resistances below pre suctioning values. However the decrease in peep } \\
\text { following tracheal suctioning suggests an increase of expiratory flow. B2 adrenergic receptor } \\
\text { blockade fails to suppress the suctioning induced broncho-constrictor response. }\end{array}$ \\
\hline $\begin{array}{l}\text { Reviewer } \\
\text { Comment }\end{array}$ & $\begin{array}{l}\text { Even with a low suction / vacuum pressure as reported here inserting the catheter deeply } \\
\text { within the tracheobronchial tree induces a broncho constrictor response. This may be seen also } \\
\text { after bronchoscopy. }\end{array}$ \\
\hline
\end{tabular}




\begin{tabular}{|c|c|}
\hline Study 15 & $\begin{array}{l}\text { Celik, S.S. \& Elbas, N.O. The standard of suction for patients undergoing endotracheal } \\
\text { intubation. Intensive Crit Care Nurs 16, 191-198 (2000). }\end{array}$ \\
\hline Method & Quasi experimental. \\
\hline Subjects & 60 patients 30 in each group. \\
\hline Approach & $\begin{array}{l}\text { The aim of this study was to determine whether a standard method of endotracheal (ET) } \\
\text { suctioning had any impact on patient care, by using an experimental study design to compare } \\
\text { the results of two different methods of ET suctioning in a cardiovascular surgery intensive } \\
\text { care unit. }\end{array}$ \\
\hline $\begin{array}{l}\text { Vacuum } \\
\text { Pressure }\end{array}$ & $\begin{array}{l}\text { Neg } 300 \mathrm{~mm} \mathrm{Hg} \text { due to no other regulator being available to supply recommended minus } 120 \\
\mathrm{~mm} \mathrm{Hg.} \mathrm{(author).}\end{array}$ \\
\hline Finding & $\begin{array}{l}\text { All nurses applying ET suction should be encouraged to follow the methods recommended by } \\
\text { the literature by providing them with appropriate suction equipment and adjusting the } \\
\text { working environment. }\end{array}$ \\
\hline $\begin{array}{l}\text { Reviewer } \\
\text { Comment }\end{array}$ & $\begin{array}{l}\text { An interesting paper with regard to the benefits of adopting an evidence based guide to } \\
\text { practice. Even though the ideal suction regulator was not available significant result were } \\
\text { observed by using the regulator that was available and introducing a' standard of practice'. }\end{array}$ \\
\hline
\end{tabular}

\begin{tabular}{|c|c|}
\hline Study 16 & $\begin{array}{l}\text { Cereda, M., et al. Closed system endotracheal suctioning maintains lung volume during } \\
\text { volume controlled mechanical ventilation. Intensive Care Medicine 27, 648-652 (2001). }\end{array}$ \\
\hline Method & Prospective randomised study. \\
\hline Subjects & 10 patients. \\
\hline Approach & Comparing open vs. closed suction systems with an eye to minimising lung volume loss. \\
\hline $\begin{array}{l}\text { Vacuum } \\
\text { Pressure }\end{array}$ & Negative pressure of $100 \mathrm{~mm} \mathrm{Hg}$. Deep, 'until resistance is met' suction method. \\
\hline Finding & $\begin{array}{l}\text { Hyper inflation and hyper oxygenation fail to maintain lung volumes during suctioning. There } \\
\text { has been increasing attention toward ventilatory strategies aimed at optimizing alveolar } \\
\text { recruitment. In this context, avoiding suction related lung volume loss can be helpful in } \\
\text { patients increased tendency to alveolar collapse. }\end{array}$ \\
\hline $\begin{array}{l}\text { Reviewer } \\
\text { Comment }\end{array}$ & $\begin{array}{l}\text { While the risk of significant negative pressure occurring in the lung during closed suctioning } \\
\text { with volume control ventilation has been postulated, we see here an example of a regulated } \\
\text { suction / vacuum pressure and modern micro processor controlled ventilator ameliorating this } \\
\text { concern. } \\
\text { The advantage of avoiding ventilator disconnection and deep suctioning may be of benefit. }\end{array}$ \\
\hline
\end{tabular}




\begin{tabular}{|l|l|}
\hline Study 17 & $\begin{array}{l}\text { Frengley, R.W., Closey, D.N., Sleigh, J.W. \& Torrance, J.m. The Effect of Closed System } \\
\text { Suction on Airway Pressures when using Servo 300 Ventilator. Critical Care and } \\
\text { Resuscitation 3,230-235 (2001). }\end{array}$ \\
\hline Method & Quasi experimental. \\
\hline Subjects & 16 patients Adult Intensive Care. \\
\hline Approach & $\begin{array}{l}\text { Aim was to measure airway pressure during closed system suctioning with the ventilator set to } \\
\text { three differing modes of ventilation. }\end{array}$ \\
\hline Vacuum & $\begin{array}{l}\text { Negative pressure of -500 cm H2O.or 368mm Hg. was described. Size 14 Fr catheter and size } \\
8 \text { ETT. The flow developed was 40 L/min. Catheter insertion 2cm below end of ETT. }\end{array}$ \\
\hline Finding & $\begin{array}{l}\text { The degree of negative airway pressure generated by suctioning depends upon the balance } \\
\text { between the inspiratory of gas and the rate at which gas is removed by suctioning. }\end{array}$ \\
\hline $\begin{array}{l}\text { Reviewer } \\
\text { Comment }\end{array}$ & $\begin{array}{l}\text { Highlights the importance of matching ventilator capabilities to suction technique as well as } \\
\text { describing the large airflows developed and subsequent effect this may have on lung volume } \\
\text { or collapse. Using a large amount of suction / vacuum pressure. }\end{array}$ \\
\hline
\end{tabular}

\begin{tabular}{|l|l|}
\hline Study 18 & $\begin{array}{l}\text { Leur, J.P., Zwaveling, J.H., Loef, B.G. \& Schans, C.P. Endotracheal suctioning versus } \\
\text { minimally invasive airway suctioning in intubated patients: a prospective randomised } \\
\text { controlled trial. Intensive Care Medicine 29, 426-432 (2003). }\end{array}$ \\
\hline Method & Prospective randomised controlled trial. \\
\hline Subjects & 383 patients intubated for more than 24 hours. \\
\hline Approach & $\begin{array}{l}\text { Routine endotracheal suctioning (n=197) was compared with on demand minimally invasive } \\
\text { suctioning (n=186) with a catheter only } 29 \mathrm{~cm} \text { long. }\end{array}$ \\
\hline Pacuum & Negative pressure 200 to $400 \mathrm{~mm} \mathrm{Hg.}$ \\
\hline Finding & $\begin{array}{l}\text { This study demonstrates that minimally invasive airway suctioning in intubated ICU patients } \\
\text { had fewer side effects than routine, deep endotracheal suctioning without being inferior in } \\
\text { terms of duration of intubation, length of stay or mortality. Mucosal bleeding may have been } \\
\text { the effect of direct damage of the catheter introduced into the airway, but could have been also } \\
\text { related to the negative pressure applied and to the technique of suctioning. }\end{array}$ \\
\hline $\begin{array}{l}\text { Reviewer } \\
\text { Comment }\end{array}$ & $\begin{array}{l}\text { A randomised control trial with a larger number of participants demonstrating an advantage of } \\
\text { minimally invasive ventilation although reporting suction / vacuum of up to } 400 \text { mm Hg. }\end{array}$ \\
\hline
\end{tabular}




\begin{tabular}{|c|c|}
\hline Study 19 & $\begin{array}{l}\text { Dyhr, T., Bonde, J. \& Lasson, A. Lung recruit manoeuvres are effective in regaining lung } \\
\text { volume and oxygenation after open endotracheal suctioning in acute respiratory distress } \\
\text { syndrome. Critical Care, } 55 \text { - } 62(2003) \text {. }\end{array}$ \\
\hline Method & A prospective randomised clinical trial. \\
\hline Subjects & 8 consecutive patients with acute lung injury. \\
\hline Approach & $\begin{array}{l}\text { Eight consecutive mechanically ventilated patients with acute lung injury or acute respiratory } \\
\text { distress syndrome were included. One of two suctioning procedures was performed in each } \\
\text { patient. In the first procedure, ETS was performed followed by LR manoeuvre and } \\
\text { reconnection to the ventilator with positive end-expiratory pressure set at } 1 \mathrm{cmH} 2 \mathrm{O} \text { above the } \\
\text { lower inflexion point, and after } 60 \text { min another ETS (but without LR manoeuvre) was } \\
\text { performed followed by reconnection to the ventilator with similar positive end-expiratory } \\
\text { pressure; the second procedure was the same as the first but conducted in reverse order. Before } \\
\text { (baseline) and over } 25 \text { min following each ETS procedure, partial arterial oxygen tension } \\
(\mathrm{PaO} 2) \text { and end-expiratory lung volume were measured. }\end{array}$ \\
\hline $\begin{array}{l}\text { Vacuum } \\
\text { Pressure }\end{array}$ & Wall suction $-400 \mathrm{~mm} \mathrm{Hg}$. Using a size 14 suction catheter inserted to just below ETT. \\
\hline Finding & $\begin{array}{l}\text { We confirmed that open ET suction per se may result in a significant drop in oxygenation and } \\
\text { in lung volume. Therefore we believe that the most important preventative measure may be to } \\
\text { avoid ETS if at all possible. }\end{array}$ \\
\hline $\begin{array}{l}\text { Reviewer } \\
\text { Comment }\end{array}$ & A very high level of vacuum but seen also in Leur 2003 (200 to $400 \mathrm{~mm} \mathrm{Hg}$ ) \\
\hline
\end{tabular}




\begin{tabular}{|c|c|}
\hline Study 20 & $\begin{array}{l}\text { Maggiore, S. \& al, e. Prevention of Endotracheal Suction Induced Alveolar Derecruitment in } \\
\text { Acute Lung Injury. American Journal of Respiratory Critical Care Medicine 167, 1215-1224 } \\
\text { (2003). }\end{array}$ \\
\hline Method & Observational. \\
\hline Subjects & $\begin{array}{l}9 \text { Patients with ALI/ARDS sedated paralysed and ventilated in volume controlled mode via } \\
\text { a size } 8 \text { ETT. }\end{array}$ \\
\hline Approach & $\begin{array}{l}\text { Comparing loss of lung volume using various open and closed suctioning techniques and } \\
\text { recruitment manoeuvres. }\end{array}$ \\
\hline $\begin{array}{l}\text { Vacuum } \\
\text { Pressure }\end{array}$ & $150 \mathrm{~mm} \mathrm{Hg}$. \\
\hline Finding & $\begin{array}{l}\text { Oxygenation paralleled lung volume changes. Suctioning induced lung derecruitment can be } \\
\text { prevented by performing recruitment manoeuvres during suctioning and minimized by } \\
\text { avoiding disconnection. }\end{array}$ \\
\hline $\begin{array}{l}\text { Reviewer } \\
\text { Comment }\end{array}$ & $\begin{array}{l}\text { Although describing a level of suction / vacuum pressure of } 150 \mathrm{~mm} \mathrm{Hg} \text { a loss of functional } \\
\text { lung volume is described. }\end{array}$ \\
\hline
\end{tabular}

\begin{tabular}{|l|l|}
\hline Study 21 & $\begin{array}{l}\text { Fernandez, M.-d.-M., Piacentini, E., Blanch, L. \& Fernandez, R. Changes in lung volume } \\
\text { with three systems of endotracheal suctioning with and without preoxygenation in patients } \\
\text { with mild to moderate lung failure. Intensive Care Medicine 30, 2210-2215 (2004). }\end{array}$ \\
\hline Method & Prospective crossover study. \\
\hline Subjects & 10 patients. \\
\hline Approach & $\begin{array}{l}\text { To compare changes in lung volume, oxygenation, airway pressure and haemodynamic } \\
\text { effects induced by suctioning. To evaluate the effects of hyper-oxygenation applied prior to } \\
\text { the manoeuvre as suggested by some guidelines. }\end{array}$ \\
\hline $\begin{array}{l}\text { Vacuum } \\
\text { Pressure }\end{array}$ & $\begin{array}{l}\text { Negative suction pressure of } 150 \text { to } 200 \text { mm Hg. Size 14Fr catheter in } 8.5 \mathrm{~mm} \text { ID ET tube, } \\
\text { Inserted 20mm to 30 mm from tip of the ET tube. }\end{array}$ \\
\hline Finding & $\begin{array}{l}\text { The reductions in lung volume during suctioning were similar with the quasi-closed (386+/- } \\
124 \mathrm{ml}) . \text { And closed system (497+/- 338ml), but significantly higher with the open system } \\
(1281+/-656 \text { ml).With or without preoxygenation lung volume returned to normal in ten } \\
\text { minutes. }\end{array}$ \\
\hline $\begin{array}{l}\text { Reviewer } \\
\text { Comment }\end{array}$ & $\begin{array}{l}\text { Here we see how ventilator disconnection alone results in lung volume loss. With a regulated } \\
\text { pressure and length of catheter insertion. }\end{array}$ \\
\hline
\end{tabular}




\begin{tabular}{|c|c|}
\hline Study 22 & $\begin{array}{l}\text { Lasocki, S., et al. Open and Closed circuit endotracheal suctioning in acute lung injury. } \\
\text { Efficiency and effects on gas exchange. Anaesthesiology 104, 39-46 (2006). }\end{array}$ \\
\hline Method & Observational Study. \\
\hline Subjects & 18 patients with acute lung injury. \\
\hline Approach & $\begin{array}{l}\text { A two part study aimed comparing gas exchange and efficiency between OES and CES } \\
\text { performed at two levels of negative pressure. }\end{array}$ \\
\hline $\begin{array}{l}\text { Vacuum } \\
\text { Pressure }\end{array}$ & $300 \mathrm{~mm} \mathrm{Hg}$ and $150 \mathrm{~mm} \mathrm{Hg}$ Catheter inserted until resistance is felt and withdrawn $2 \mathrm{~cm}$. \\
\hline Finding & $\begin{array}{l}\text { Closed circuit endotracheal suctioning followed by a recruitment manoeuvre prevents } \\
\text { hypoxemia resulting from open endotracheal suction but decreases secretion removal. } \\
\text { Increasing suction pressure enhances suctioning efficiency without impairing gas exchange. }\end{array}$ \\
\hline $\begin{array}{l}\text { Reviewer } \\
\text { Comment }\end{array}$ & $\begin{array}{l}\text { Suggests that increasing the level of vacuum increases secretion removal while the greatest } \\
\text { loss of lung volume occurs with circuit disconnection. Does increasing vacuum cause more } \\
\text { secretion production? Similar to the previous study only with higher suction pressures and } \\
\text { deep catheter insertion. }\end{array}$ \\
\hline
\end{tabular}

\begin{tabular}{|c|c|}
\hline Study 23 & $\begin{array}{l}\text { Morrow, B., Futter, M. \& Argent, A. Effect of endotracheal suction on lung dynamics in } \\
\text { mechanically - ventilated paediatric patients. Australian Journal of Physiotherapy 52, } 121 \text { - } \\
126 \text { (2006). }\end{array}$ \\
\hline Method & prospective observational study. \\
\hline Subjects & 65 patients 0.3 to 24 months in age. \\
\hline Approach & $\begin{array}{l}\text { This study aimed to determine the immediate effect of endotracheal suctioning on dynamic } \\
\text { compliance, tidal volume and airway resistance in mechanically ventilated paediatric patients. }\end{array}$ \\
\hline $\begin{array}{l}\text { Vacuum } \\
\text { Pressure }\end{array}$ & Neg 360 mm Hg. Occlusion pressure. (High ). \\
\hline Finding & $\begin{array}{l}\text { No evidence that suctioning reduces airway resistance. In this study we recorded an overall } \\
\text { decrease n dynamic compliance and Vte. mech following standardized single episode of } \\
\text { tracheal suctioning. These results support the findings of Branstater } 1969 \text { who documented a } \\
\text { consistent fall in compliance. }\end{array}$ \\
\hline $\begin{array}{l}\text { Reviewer } \\
\text { Comment }\end{array}$ & A larger sample size but a high vacuum level in the pediatric setting. \\
\hline
\end{tabular}




\begin{tabular}{|c|c|}
\hline Study 24 & $\begin{array}{l}\text { Heinze, H., Sedemund-Adib, B., Herringlake, M., Gosch, U. \& Eichler, W. Functional } \\
\text { residual capacity changes after different endotracheal suctioning methods. Anesthesia and } \\
\text { Analgesia 107, 941-944 (2008). }\end{array}$ \\
\hline Method & Randomised crossover study. \\
\hline Subjects & $\begin{array}{l}20 \text { post op cardiac surgery patients. Certain patients may have very pronounced changes in } \\
\text { FRC. }\end{array}$ \\
\hline Approach & $\begin{array}{l}\text { To compare the effects of three different ETS procedures; CS-PCV, CS-VCV and Open } \\
\text { suctioning (OS) on functional residual capacity (FRC). }\end{array}$ \\
\hline $\begin{array}{l}\text { Vacuum } \\
\text { Pressure }\end{array}$ & $\begin{array}{l}150 \mathrm{~mm} \text { Hg. Size } 14 \text { FR catheter inserted until resistance is felt and withdrawn } 2 \mathrm{~cm} \text {. } \\
\text { Combined with either a size } 8 \text { or } 7.5 \text { ID ET tube. }\end{array}$ \\
\hline Finding & FRC is reduced in all cases. \\
\hline $\begin{array}{l}\text { Reviewer } \\
\text { Comment }\end{array}$ & $\begin{array}{l}\text { While cardiac surgery may be inclined to lose FRC it may have been interesting to adopt a } \\
\text { less invasive method than inserting the catheter until resistance was met or deeply into the } \\
\text { respiratory tree. The size } 14 \text { catheter is large for a size } 7 \text { ET tube, perhaps. }\end{array}$ \\
\hline
\end{tabular}

\begin{tabular}{|l|l|}
\hline Study 25 & $\begin{array}{l}\text { Briassoulis, G., et al. The Effects of Endotracheal Suctioning on the Accuracy of Oxygen } \\
\text { Consumption and Carbon Dioxide Production Measurements and Pulmonary Mechanics } \\
\text { Calculated by Compact Metabolic Monitor. Anesthesia and Analgesia 109, 873-879 (2009). }\end{array}$ \\
\hline Method & Prospective observational clinical study. \\
\hline Subjects & 11 mechanically ventilated children. \\
\hline Approach & $\begin{array}{l}\text { Investigating the effects of ETS on the accuracy of O2 consumption and CO2 measurement } \\
\text { and calculated lung mechanics, respiratory quotient and resting energy expenditure in } \\
\text { mechanically ventilated children using a compact metabolic monitor. }\end{array}$ \\
\hline $\begin{array}{l}\text { Vacuum } \\
\text { Pressure }\end{array}$ & $\begin{array}{l}\text { P=-250mm Hg (-33kPa or -4.8psi) occlusion pressure catheter inserted just below ETT i.e., } \\
\text { shallow }\end{array}$ \\
\hline Finding & $\begin{array}{l}\text { Pulmonary mechanics and indirect calorimetry measurements are not influenced after } \\
\text { uneventful open ETS in well sedated patients. The metabolic monitor is able to reliably record } \\
\text { spirometry and metabolic indices as early as 5 minutes after suctioning at different ventilator } \\
\text { modes. }\end{array}$ \\
\hline $\begin{array}{l}\text { Reviewer } \\
\text { Comment }\end{array}$ & $\begin{array}{l}\text { Carefully measured depth of suction although at a reasonably high vacuum occlusion pressure } \\
\text { in 'well sedated patients'. Reading s taken 5 minutes after the event may not capture adverse } \\
\text { effects during the suctioning event. Others have reported a return to baseline after 5 minutes. } \\
\text { See also Seymour 2009 below. }\end{array}$ \\
\hline
\end{tabular}




\begin{tabular}{|c|c|}
\hline Study 26 & $\begin{array}{l}\text { Grivans, C., Lindren, S., Aneman, A., Stenqvst, O. \& Lundin, S. A Scandinavian survey } \\
\text { of drug administration through inhalation, suctioning and recruitment manoeuvres in } \\
\text { mechanically ventilated patients. Acta Anaesthesiologica 53,710-716 (2009). }\end{array}$ \\
\hline Method & prospective clinical audit / survey. \\
\hline Subjects & *87 ICUs out of 161 answered the survey. \\
\hline Approach & $\begin{array}{l}\text { Aim was to describe current practices for drug administration through inhalation, } \\
\text { endotracheal suctioning and lung recruitment manoeuvres in mechanically ventilated } \\
\text { patients in Scandinavian Intensive care Units. }\end{array}$ \\
\hline Vacuum Pressure & $45 \%$ less than $-20 \mathrm{kPa}, 29 \%$ set above $-30 \mathrm{KPa}$. (150mm Hg.) \\
\hline Finding & $\begin{array}{l}\text { While clinical guidelines for endotracheal suction recommend a vacuum level of } 13 \mathrm{kPa} \text {. } \\
\text { In this survey more negative pressure was used in clinical practice, with an obvious risk } \\
\text { for derecruitment. }\end{array}$ \\
\hline Reviewer Comment & $\begin{array}{l}\text { Not a "human study", but a review of practice. But informs some of the outcome of } \\
\text { interest criteria. }\end{array}$ \\
\hline
\end{tabular}

\begin{tabular}{|c|c|}
\hline Study 27 & $\begin{array}{l}\text { Lindgren, S., et al. Bronchoscopic suctioning may cause lung collapse: a lung model and } \\
\text { clinical evaluation Acta Anaesthesiologica Scandinavia 52, 209-218 (2008) }\end{array}$ \\
\hline Method & Bench test and Quasi- experimental. \\
\hline Subjects & 13 patients in an Adult ICU with acute lung injury. \\
\hline Approach & $\begin{array}{l}\text { We hypothesized that suctioning might cause substantial and sustained changes in respiratory } \\
\text { pattern, volume and other variables that are important in assessing a patients readiness for } \\
\text { discontinuation of ventilatory support. }\end{array}$ \\
\hline $\begin{array}{l}\text { Vacuum } \\
\text { Pressure }\end{array}$ & Negative $\mathrm{p}$ less than $200 \mathrm{~mm} \mathrm{Hg}$. Size 14 catheter $30 \mathrm{~cm}$ long. \\
\hline Finding & $\begin{array}{l}\text { Post suction changes in measured variables persist longer in these spontaneously breathing } \\
\text { patients weaning from mechanical ventilation than in patients who are sedated and paralysed. } \\
\text { The effects of suction on cardiopulmonary function should be considered in practice and } \\
\text { during the design of future studies. }\end{array}$ \\
\hline $\begin{array}{l}\text { Reviewer } \\
\text { Comment }\end{array}$ & $\begin{array}{l}\text { The Bronchoscope although almost } 5 \mathrm{~mm} \text { in diameter has room for only a } 2 \mathrm{~mm} \text { suction } \\
\text { channel with perhaps the suction power of a size } 8 \text { or } 10 \text { French suction catheter. }\end{array}$ \\
\hline
\end{tabular}




\begin{tabular}{|c|c|}
\hline Study 28 & $\begin{array}{l}\text { Seymour, C., Cross, B., Cooke, C., Gallop, R. \& Fuch, B. Physiologic impact closed system } \\
\text { endotracheal suctioning in spontaneously breathing patients receiving mechanical ventilation. } \\
\text { Respiratory Care 54, 367-374 (2009). }\end{array}$ \\
\hline Method & Prospective cohort study. \\
\hline Subjects & 29 Patients, mechanically ventilated in a university hospital medical intensive care unit. \\
\hline Approach & $\begin{array}{l}\text { We hypothesized that suctioning might cause substantial and sustained changes in respiratory } \\
\text { pattern, volume and other variables that are important in assessing a patients readiness for } \\
\text { discontinuation of ventilatory support. }\end{array}$ \\
\hline $\begin{array}{l}\text { Vacuum } \\
\text { Pressure }\end{array}$ & Negative pressure regulated to less than $200 \mathrm{~mm} \mathrm{Hg}$. Size 14 catheter $30 \mathrm{~cm}$ long. \\
\hline Finding & $\begin{array}{l}\text { Post suction changes in measured variables persist longer in these spontaneously breathing } \\
\text { patients weaning from mechanical ventilation than in patients who are sedated and paralysed. } \\
\text { The effects of suction on cardiopulmonary function should be considered in practice and } \\
\text { during the design of future studies. }\end{array}$ \\
\hline $\begin{array}{l}\text { Reviewer } \\
\text { Comment }\end{array}$ & $\begin{array}{l}\text { An interesting study describing the more significant effects of suctioning on the less well } \\
\text { sedated patients. }\end{array}$ \\
\hline Study 29 & $\begin{array}{l}\text { Soares dePaula, L.C.S. \& Ceccon, M.E.J. randomised comparative analysis between two } \\
\text { tracheal suction systems in neonates. Rev Assoc Med Bras 56, 434-439 (2010). }\end{array}$ \\
\hline Method & A prospective randomized controlled study \\
\hline Subjects & 39 newborn infants. \\
\hline Approach & $\begin{array}{l}\text { Methods. A prospective randomized controlled study was carried out with } 39 \text { newborn infants } \\
\text { of gestational age } \geq 34 \text { weeks using pressure-limited, time-cycled, continuous-flow } \\
\text { mechanical ventilators. } \\
\text { The infants were classified into two groups according to ventilatory parameters: Group I was } \\
\text { ventilated using positive end-expiratory pressure (PEEP) } \geq 5 \mathrm{~cm} \mathrm{H} 2 \mathrm{O} \text { and mean airway } \\
\text { pressure (MAP) } \geq 8 \mathrm{~cm} \mathrm{H} 2 \mathrm{O} \text {; and Group II using PEEP }<5 \mathrm{~cm} \mathrm{H} 2 \mathrm{O} \text { and MAP }<8 \mathrm{~cm} \mathrm{H} 2 \mathrm{O} \text {. }\end{array}$ \\
\hline $\begin{array}{l}\text { Vacuum } \\
\text { Pressure }\end{array}$ & $\begin{array}{l}\text { level: A suction catheter } \# 6 \text { or } \# 8 \text {, according to the size of the endotracheal tube, }(2.5,3.0,3.5 \text {, } \\
\text { and } 4 \mathrm{~cm} \text { ) was inserted only twice during each procedure, and the time interval between } \\
\text { insertions was three minutes. The negative pressure used during suctioning was } 150 \text { to } 200 \\
\mathrm{~mm} \text {. Hg. }\end{array}$ \\
\hline Finding & $\begin{array}{l}\text { Results. No statistically significant differences were observed when OSS and CSS were } \\
\text { compared in both groups. There was a statistically significant improvement in post-procedure } \\
\text { oxygen saturation in both groups. The study showed a decrease in functional residual capacity } \\
\text { after suctioning, regardless of the system used. }\end{array}$ \\
\hline $\begin{array}{l}\text { Reviewer } \\
\text { Comment }\end{array}$ & $\begin{array}{l}\text { This study may show that } 150 \text { to } 200 \mathrm{~mm} \mathrm{Hg} \text { vacuum pressure results in lung volume loss in } \\
\text { neonates. It is certainly above what is generally recommended, but that aside represents a } \\
\text { controlled and minimally invasive method of ET suctioning. }\end{array}$ \\
\hline
\end{tabular}




\begin{tabular}{|c|c|}
\hline Study 30 & $\begin{array}{l}\text { Corley, A., Coruana, L. \& Barnett, A. Open and closed suctioning result in significant lung } \\
\text { derecruitment. Anaesthesia and Intensive Care 38. (2010). }\end{array}$ \\
\hline Method & A randomised controlled study. \\
\hline Subjects & 2 female and 18 male patients. \\
\hline Approach & $\begin{array}{l}\text { Aim was to optimise alveolar recruitment and positive lung volume, thereby attenuating } \\
\text { ventilator induced lung injury. Open vs. closed suctioning. Electrical impedance tomography. }\end{array}$ \\
\hline $\begin{array}{l}\text { Vacuum } \\
\text { Pressure }\end{array}$ & Neg 120 mm Hg. \\
\hline Finding & $\begin{array}{l}\text { Lung volume loss was observed during both open and closed suctioning at a vacuum pressure } \\
\text { of } 120 \mathrm{~mm} \mathrm{Hg} \text {. Open }=2321 \text { units and closed }=1416 \text { units. }\end{array}$ \\
\hline $\begin{array}{l}\text { Reviewer } \\
\text { Comment }\end{array}$ & $\begin{array}{l}\text { Amanda Corley kindly set me her paper ahead of publication after the appearance of an } \\
\text { abstract in Anaesthesia and Intensive Care. While apparently remaining suspicious of closed } \\
\text { suction interesting results may be extracted considering these demonstrated lung volume } \\
\text { losses if compared with vacuums presented by an unguarded wall suction outlet. ( } 550 \mathrm{~mm} \mathrm{Hg} \text { ) }\end{array}$ \\
\hline
\end{tabular}




\section{Appendix VI. List of Excluded Studies}

While of interest to the discussion of the issues surrounding the practice of endotracheal suctioning these studies did not present data with regard to the effect of suction vacuum pressure on the outcomes of interest for this review.

1. Waters RM. Tracheobronchial Toilet. British Journal of Anaesthesia. 1942;18(1). Reasons for exclusion: Outcomes of interest regarding level of vacuum pressure and its influence on study results were not reported.

2. Nunn JF, Ezi-Ashi TI. The respiratory effects of resistance to breathing in anesthetised man. Anesthesiology. 1961;22(2):174 - 85.

Reasons for exclusion: Outcomes of interest regarding level of vacuum pressure and its influence on study results were not reported.

3. Shim C, Fine N, Fernandez R, Williams MH. Cardiac arrythmias resulting from tracheal suctioning. Annals of Internal Medicine. 1969;71(6):1149 - 53.

Reasons for exclusion: Outcomes of interest regarding level of vacuum pressure and its influence on study results were not reported.

4. Mehta S. The risk of aspiration in presence of cuffed endotracheal tubes. Brit J Anaesth. 1972;44:601 - 5.

Reasons for exclusion: Outcomes of interest regarding level of vacuum pressure and its influence on study results were not reported.

5. Loubser MD, Mahoney PJ, Milligan DWA. Hazards of routine endotracheal suction in the neonatal unit. The Lancet. 1989(June 24):144 - 5.

Reasons for exclusion: Outcomes of interest regarding level of vacuum pressure and its influence on study results were not reported.

6. Cook D, De-Jonghe B, Brochard L, Brun-Buisson C. Influence of airway management on ventiator - associated pneumonia. JAMA. 1998;279(10):781 - 7. Reasons for exclusion: Outcomes of interest regarding level of vacuum pressure and its influence on study results were not reported.

7. Guglielminotti J, Alzieu M, Maury E, Guidet B, Offenstadt G. Bedside detection of retained secretions in patients receiving mechanical ventilation. Is it time for suctioning. Chest. 2000; 118 (4):1095 - 9.

Reasons for exclusion: Outcomes of interest regarding level of vacuum pressure and its influence on study results were not reported. 
8. Lapinsky S. Recruitment and retention of lung volume (commentary). Critical Care. 2002; 7:9-10.

Reasons for exclusion: Outcomes of interest regarding level of vacuum pressure and its influence on study results were not reported.

9. Rabitsch W, Kostler W, Fiebiger W, al e. Closed suctioning system reduces crosscontamination between bronchial system and gastric juices. Anesthesia and Analgesia. 2004; 99:886-92.

Reasons for exclusion: Outcomes of interest regarding level of vacuum pressure and its influence on study results were not reported.

10. Ridling DA, Martin LD, Bratton SL. Endotracheal suctioning with or without installation of isotonic sodium chloride solution in critically ill children. Am J Crit Care. 2003; 12 (212-219).

Reasons for exclusion: Outcomes of interest regarding level of vacuum pressure and its influence on study results were not reported.

11. Hedenstierna G. Alveolar collapse and closure of airways; regular effects of anaesthesia. Clinical Physiology and Functional Imaging. 2003; 23 (2):123 - 9.

Reasons for exclusion: Outcomes of interest regarding level of vacuum pressure and its influence on study results were not reported.

12. Abbas SM, Hoda MQ, Department of Anaesthesiology AKUH, Karachi. Negative Pressure Pulmonary Edema: Case Report. Journal of Pakistan Medical Association. [Case report]. 2004 Jul 2004; 54 (7):396-8.

Reasons for exclusion: Outcomes of interest regarding level of vacuum pressure and its influence on study results were not reported.

13. Heinze H, Sedemund-Adib B, Herringlake M, Gosch U, Eichler W. Functional residual capacity changes after different endotracheal suctioning methods. Anesthesia and Analgesia. 2008; 107 (3):941-4.

Reasons for exclusion: Outcomes of interest regarding level of vacuum pressure and its influence on study results were not reported.

14. Kaiser JR, Gauss CH, Williams DK. Tracheal suctioning is associated with prolonged disturbances of cerebral hemodynamics in very low birth weight infants. Journal of Perinatology. 2008; 28:34-41.

Reasons for exclusion: Outcomes of interest regarding level of vacuum pressure and its influence on study results were not reported. 
15. George KJ. A systematic approach to care; adult respiratory distress syndrome. Journal of Trauma Nursing. 2008; 15 (1):19 - 22.

Reasons for exclusion: Outcomes of interest regarding level of vacuum pressure and its influence on study results were not reported.

16. Jung JW, Choy EH, Kim JH, et al. Comparison of a closed with an open endotracheal suction; costs and the incidence of ventilator associated pneumonia. Tuberculosis and respiratory disease. 2008; 65 (3):198 - 206.

Reasons for exclusion: Outcomes of interest regarding level of vacuum pressure and its influence on study results were not reported.

17. Caruso P, Denari S, Ruiz S, Demarzo S, Deheinzelin D. Saline instillation before tracheal suctioning decreases the incidence of ventilator associated pneumonia. Crit Care Med. 2009;37(1):32 - 8.

Reasons for exclusion: Outcomes of interest regarding level of vacuum pressure and its influence on study results were not reported.

18. Larsson A. Inhale, suction and close the lung: a common clinical practice in Scandinavian intensive care units. Acta Anaesthesiologica. [Editorial]. 2009;53:699-700

Reasons for exclusion: Outcomes of interest regarding level of vacuum pressure and its influence on study results were not reported. 


\section{Appendix VII. References cited in previous publications}

These are the references cited in previous systematic reviews, meta-analyses and expert guides to endotracheal or tracheal suctioning.

Rosen M and Hillard E K: The effects of negative pressure during tracheal suction. Anaesthesia and Thambrian K K, Ripley S H; Observations on tracheal trauma following suction. An experimental study. British Journal of Anaesthesiology 1966; 38 459-462.

Fell T and Cheney F W. Prevention of hypoxia during endotracheal suction. Annals of Surgery 1971; 174(1): 24-28.

Sackner M A, Landa J F, Greeneltch N. Pathogenesis and prevention of tracheobronchial damage with suction procedures. Chest 1973; 64(3) 284-290.

Kuzenski B. Effect of negative pressure on tracheobronchial trauma. Nursing Research 1978; 27: 260-263.

Skelly B F H, Deeren S M, Powaser M M. The effectiveness of two preoxygenation methods to prevent endotracheal suctioning hypoxemia. Heart and Lung 1980; 9:316.

Gibson I. Tracheostomy management. Nursing 198318 538-541.

Young C S. Recommended guidelines for suction. Physiotherapy 1984; 70(3): 106-108.

Fluck R R. 1985. Suctioning- Intermittent or continuous? Respiratory Care, 1985; 30: 837838.

Goodenough SKC. The effects of oxygen and hyperinflation on arterial oxygen after endotracheal suctioning. Heart and Lung: Journal of Critial Care; 1985; 14(1): 11-17.

Serra A, Bailey C M, Jackson P. Ear, Nose and Throat Nursing. Blackwell scientific. Oxford 1986.

Rudy E B, Baun M, Stone K, Turner B. The relationship between endotracheal suctioning and changes in intracranial pressure: a review of the literature. Heart and Lung 1986; 15(5): 488-494.

Shekelton M, Nield D M. Ineffective airway clearance related to artificial airways. Nurs Clin North Am 1987; 22(1): 167-178.

Mapp G S. Trach care. Are you aware of all the dangers? Nursing88 1988; 18(7): 32-42. 
Reagan M. Tracheal - mucosal injury - the nurses role. Nursing 1988; 29(3): 1064-6.

Preusser B A, Stone K S, Gonyon D S, Winningham M L, Groch K F, Karl J E. Effects of two methods of preoxygenation on mean arterial pressure, cardiac output, peak airway pressure and post suctioning hypoxemia. Heart and Lung; Journal of Critical Care. 1988; 17(3): 290-299.

Martin L K. Management of the altered airway in the head and neck cancer patient. Semin Oncol Nurs.1989: 5(3): 182-90.

Stone K S, Vorst E C, Zahn S. Effects of lung hyperinflation on mean arterial pressure and post suctioning hypoxemia. Heart and Lung 1989; 18(4): 377-385.

Clark A P, Winslow E H, Tyler D O, White K M. Effects of endotracheal suctioning on mixed venous oxygen saturation and heart rate in critically ill adults. Heart and Lung: Journal of Critical Care.1990; 19(5 part 2): 552-557.

Tenaillon A. Tracheobronchial suction during mechanical ventilation. Update Intensive Care Emerg Med. 1990; 10: 1996-200.

Gray J E et al. The effects of bolus normal saline instillation in conjunction with endotracheal suctioning. Respiratory Care, 1990; 35(8): 785-790.

Lookinland S, Appel P L. Hemodynamic and oxygen transport changes following endotracheal suctioning in trauma patients. Nursing Research 1991; 40(3): 133-138.

Hodge D. Endotracheal suctioning and the infant: a nursing care protocol to reduce complications. Neonatal Network 1991; 9:7-15.

Czarnik R E, Stone K S, Everhart C C, Preusser B A. Differential effects of continuous versus intermittent suction tracheal tissue. Heart and Lung. March 1991; 20 (2):144-151.

Singh N C, Kissoon N, Frewen T, et al. Physiological responses to endotracheal and oral suctioning in paediatric patients: The influence of endotracheal tube sizes and suction pressures. Clinical Intensive Care, 1991: 2:345-350.

Fiorentini A. Potential hazards of tracheobronchial suctioning. Intensive and Critical Care Nursing. 1992; 8: 217-226.

Mancinelli- Van Arta $\mathbf{J}$ and Beck S L. Preventing hypoxemia and haemodynamic compromise related to endotracheal suctioning. American Journal of Critical Care 1992; 1:62-79 Nov.

Odell A, Adler A, Bayne R et al. Endotracheal suction for adult non-head injured patients. A review of the literature. Intensive Critical Care Nursing. 1993; 9: 274-278. 
Kerr M, Rudy E Brucia K. Head- injured adults. Recommendations for endotracheal suctioning. Journal of Neuroscience Nursing. 1993; 25(2): 86-91.

Branson R D, Cambell R S, Chatburn R L, Covington J. AARC Practice Guideline; Endotracheal suctioning of mechanically ventilated adults and children with artificial airways. Respiratory Care 1993; 38(5): 500-4.

Boggs R L. Airway Management. In Boggs R L, Woodridge-King (eds) AACN Procedure. Meyer-Holoway N. Nursing in the critically ill adult. $4^{\text {th }}$ edition 1993.California, AddisonWesley. Nov.1993; 2: 326-330.

Glass C, et al. Nurses ability to achieve hyperinflation and hyper-oxygenation with a manual inflation bag during endotracheal suctioning. Heart Lung. Mar-Apr. 1993; 22:158165.

McCabe S M, Smeltzer S C. Comparison of tidal volumes obtained by one handed and two handed ventilation techniques. American Journal of Critical Care. Nov 1993; 2: 467-473.

Ackerman M. The effect of saline lavage prior to suctioning. American Journal of Critical Care. 1993; 2; 326-330.

Luce J M, Pierson D J, Tyler M L. Intensive Respiratory Care. $2^{\text {nd }}$ Ed 1993. W B Saunders, Philadelphia.

Carroll P F. Safe Suction PRN Registered Nurse 1993, 57, 5, 32-37.

Hagler D A, and Traver G A. Endotracheal saline and suction catheters: sources of lower airway contamination. American Journal of Critical Care. Nov. 1994; 3: 444-447.

Kacmerek R M, Stoller J K. Principles of respiratory care. In Text Book of Critical Care. Third Edition. Shoemaker W C, Ayres S M, Grenvik A et al (eds). USA, WB Saunders Company 1995 pp 695.

Glass C A and Grap M J. Ten Tips for Safer Suctioning. Advanced Journal of Nursing 1995; 5: 51-53.

Hooper M. Nursing care of the patient with a tracheostomy. Nursing Standard 1996; 10(34): 40-43.

Wood C J. Endotracheal suctioning; a literature review. Intensive and Critical Nursing 1998; 14(3): 124-136.

Wood C J. Can nurses safely assess the need for endotracheal suction in short term ventilated patients instead of using routine techniques? Intensive Critical Care Nursing 1998; 14(4): 170-178. 
Griggs A. Tracheostomy suctioning and humidification. Nursing Standard. 1998; 13(2): 49-56.

McKelvie S. Endotracheal suctioning. Nursing Critical Care. 1998; 3(5): 244-248.

Buglass E. Tracheostomy care; tracheal suctioning and humidification. British Journal of Nursing, 1999; 8(8): 500-504.

Kerr M, Weber B, Sereika S, Darby J, Marion D and Orndoff P. Effect of endotracheal suctioning on cerebral oxygenation in traumatic brain injured patients. Critical Care Medicine 1999; 27(12): 2776-2781.

Blackwood B. Normal saline installation with endotracheal suctioning: primum non nocere. Journal of Advanced Nursing. 1999; 29(4): 928-934.

Thompson L. Suctioning adults with an artificial airway. The Joanna Briggs Institute for Evidence Based Nursing and Midwifery. 2000; 9. (level 1).

Day T. Best practice for tracheal suctioning. Nursing Times Plus.2000; 96(20): 13-15.

Donald K J, Robertson V J, Tsebelis K. Setting safe and effective suction pressure: The effect of using a manometer in the suction circuit. Intensive Care Medicine 2000; 26: 15 19.

Laws-Chapman C, Rushmer F, Miller R, Flanagan K, Prigmore S, Chabane S. Guidelines for the care of patients with tracheostomy tubes. St George's Healthcare NHS Trust. August 2000; page 32.

Tracheal suctioning of adults with an artificial airway, Best Practice Evidence Based Information Sheets for Health Professionals. Volume 4. Issue 4. 2000. Joanna Briggs Institute for Evidence Based Nursing and Midwifery.

Kohlhauser C, Bernert G, Hermon M, et al. Effects of endotracheal suctioning in high frequency oscillatory and conventionally ventilated low birth weight neonates on cerebral hemodynamics observed by Near infrared Spectroscopy. (NIRS). Pediatr Pulmonol. 2000; 29: 270-275.

Celik S S, Elbas N O. The standards of suction for patients undergoing endotracheal intubation. Intensive and Critical Care Nursing. 2000; 16:191-198.

Day T, Farnell S, Wilson-Barnett J. Suctioning: a review of current research recommendations. Intensive Critical Care Nursing. 2002; 18(2): 79-89.

Oh H, Seo W. A meta-analysis of the effects of various interventions in preventing endotracheal suction- induced hypoxemia, Nov 2003; 12(6): 912-924. (level1). 
Van de Leur L P, Zwaveling J H, Loef B G, Van der Schans C P. Endotracheal suctioning versus minimally invasive airway suctioning in intubated patients: a prospective randomised controlled trial. Intensive Care Medicine. 2003 Mach; 29(3): 426-432.

Morrow B, Futter M, Argent A. Endotracheal suctioning: from principles to practice. Intensive Care Medicine 2004; 30:1167-1174.

Morrow B M, An investigation into nonbrochoscopic bronchoalveolar lavage and endotracheal suctioning in critically ill infants and children. $\mathrm{PhD}$ Thesis, University of Cape Town, 2005.

Celik S A, Kanan N A. Current conflict: use of isotonic sodium chloride solution ome endotracheal suctioning in critically ill patients. Dimensions of Critical Care Nursing. 2006; Jan-Feb, 25(1):11-14.

Morrow B, Futter m, Argent A. Effect of endotracheal suction on lung dynamics in mechanically ventilated pediatric patients. Australian Physiotherapy 2006; 52: 121-126.

Subirana M, Solal, Benito S. Closed tracheal suction systems versus open suction systems for mechanically ventilated adult patients. Cochrane Database of Systematic Reviews 2007 , issue 4.

Peter J V, Chacko B, Moran J L. Comparison of closed endotracheal suction versus open endotracheal suction in the development of ventilator associated pneumonia in intensive care patients: an evaluation using meta-analytic techniques. Indian Journal Medical Science 2007 April; 61(4): 201-211.

Morrow B, Futter, Argent A, A recruitment manoeuvre performed after endotracheal suction does not increase dynamic compliance in ventilated pediatric patients: A randomised controlled trial. Australian Journal of Physiotherapy. 2007; 53: 163-169.

Pedersen C, Rosendahl-Nielsen, Hjermind J, Egerod I. Endotracheal suctioning of the adult intubated patient - what is the evidence? Intensive and Critical Nursing 2009; 25:21-30. 


\section{References}

1. Thompson L. Suctioning Adults with an Artificial Airway. A Systematic Review. The Joanna Briggs Institute for Evidence Based Nursing and Midwifery. [Systematic Review]. 20002000.

2. Pedersen C, Rosendahl-Nielsen M, Hjermind J, Egerod I. Endotracheal suctioning of the adult intubated patient - What is the evidence? Intensive and Critical Care Nursing. 2009;25:2130.

3. Rosen M, Hillard EK. The use of suction in clinical medicine. British Journal of Anaesthesia. 1960;32:486 - 504.

4. Lindgren S, Odenstedt H, Olegard C, Sondergaard S, Lundin S, Stenqvist O. Regional lung derecruitment after endotracheal suction during volume or pressure-controlled ventilation: a study using electric impedance tomography. Intensive Care Medicine. 2007;33:172 - 80.

5. Boothroyd AE, Murthy BVS, Darbyshire A, Petros AJ. Endotracheal suctioning causes right upper lobe collapse in intubated children. Acta Paediatrica. 1996;85(12):1422 - 5.

6. Fiorentini A. Potential hazards of tracheobronchial suctioning. Intensive and Critical Care Nursing. 1992;8:217 - 26.

7. Davidson S, Guinn C, Gacharna D. Diagnosis and treatment of negative pressure pulmonary edema in a pediatric patient: A case report. AANA Journal. 2004;72(5):337 - 8.

8. Lim EB, How J. A review of cases of pulmonary barotrauma from diving. Singapore Medical Journal. 1993;34:16 - 9.

9. Almgren B, Wickerts C-J, Heinonen E, Hogman M. Side effects of endotracheal suction in pressure- and volume-controlled ventilation. Chest. 2004;125:1077-80.

10. Hahn M. 10 considerations for endotracheal suctioning. RT: for decision makers in respiratory care. 2010 July 2010.

11. Munson BR, Young DF, Okiishi TH, Huebsch WW. Fundamentals of Fluid Mechanics: John Wiley \& sons; 2009.

12. Burke J. Connections a few notes. Scientific American. 1999(july):105-6.

13. Brush SG. Gadflies and geniuses in the histort of gas theory. Synthese. 1999;119(1/2):11 -

43.

14. Cornell U. Pressure conversion calculator. Cornell University Joan and Sanford Weill Medical College 
2002; Available from: http://www-users.med.cornell.edu/ spon/picu/calc/pressure.htm.

15. Australia CHS. Medical suction equipment Part 3: Suction equipment powered from a vacuum pressure source. Australian Standards. [Australian Standard]. 1992;AS 2120.3-1992.

16. Shannon A, Goldsmith A. Suction devices. Anaesthesia and Intensive Care Medicine. 2009;10(10):468-70.

17. Thompson C. Suction Systems.2010: Available from:

www.anaes.med.usyd.edu.au/lectures/suction c/t.html.

18. Carroll PL. The Principles of Vacuum and its use in the Hospital environment [Monograph.]. 2006.

19. Arbon D. Flow Rates Through Suction Catheters. [Original experimental measurements]. 2010.

20. Campos SL, Soares FC, Deus JRBd, Andrade RMd, Pinotti M. SUCTION PRESSURE BEHAVIOR IN FUNCTION OF THE HOLES IN THESUCTION DEVICES OF LUNG SECRETIONS. Proceedings of COBEM 2005 18th International Congress of Mechanical Engineering. 2005;November 6-11, 2005, Ouro Preto, MG.

21. Kiraly N, Tingay D, Mills J, Morley C, Copnell B. Negative Tracheal Pressure During Neonatal Endotracheal Suction. Pediatric Research. 2008;64(29 - 33).

22. Lumholt N. Design and function of tracheal suction catheters. Acta Anaesthesiologica Scandinavia. 1982;26:1-3.

23. Rosen $\mathrm{M}$, Hillard $\mathrm{E}$. The effects of negative pressure during tracheal suction. Anesthesia ans Analgesia. 1962;41(1):50 - 8.

24. Vanner R, Bick E. Tracheal pressures during open suctioning. Anaesthesia. 2008(63):313 5.

25. Gleick J. Chaos. Making a new science. New York: Open Road Integrated Media; 2011.

26. Schmidt A, Zidowitz S, Kriete A, Denhard T, Crass S, Peitgen HO. A digital reference model of the human bronchial tree. Computerized Medical Imaging and Graphics. 2004;28:203-11.

27. Kitaoka H, Takaki R, Suki B. A three-dimensional model of the human airway tree. Journal of Applied Physiology. 1999;87:2207 - 17.

28. Lindgren S, Odenstedt H, Erlandsson K, Grivans C, Lundin S, Stenqvist O. Bronchoscopic suctioning may cause lung collapse: a lung model and clinical evaluation Acta Anaesthesiologica Scandinavia. 2008;52:209-18. 
29. Leur JP, Zwaveling JH, Loef BG, Schans CP. Endotracheal suctioning versus minimally invasive airway suctioning in intubated patients: a prospective randomised controlled trial. Intensive Care Medicine. 2003;29:426-32.

30. Mu P-F, Wang K-WK, Chen Y-C, Tsay S-F. A Systematic review of the experiences of adult ventilator dependent patients. JBI Library of Ststematic Reviews. [Qualitative Systematic review.]. 2010;JBL000251(2010;8(8).):343-81.

31. Broccard AF, Liaudet L, Aubert J-D, Schnyder P, Schaller M-D. Negative Pressure PostTracheal Extubation Alveolar Hemorrhage. Anesthesia and Analgesia. 2001;92:273 - 5.

32. Ackland GL, Mythen MG. Negative Pressure Pulmonary Edema as an Unsuspected Imitor of Acute Lung Injury / ARDS. Chest. [Editorial]. 2005;127:1867 - 8.

33. Abbas SM, Hoda MQ, Department of Anaesthesiology AKUH, Karachi. Negative Pressure Pulmonary Edema: Case Report. Journal of Pakistan Medical Assiciation. [Case report]. 2004 Jul 2004;54(7):396-8.

34. Fremont RD, Kallet RH, Matthay MA, Ware LB. Postobstructive Pulmonary Edema. A case for hydrostatic mechanisms. Chest. [A retrospective review of 341 patients]. 2007;131:1742 - 6 . 35. Langenderfer B. A case of negative pressure pulmonary oedema after breast implant surgery. Internet Journal of Pulmonary Medicine. [Case Study]. 2005;5(2).

36. Pang WW, Chang DP, Huang MH. Negative pressure pulmonary oedema induced dy direct suctioning of endotracheal tube adapter. Canadian Journal of Anaesthesia. [case report]. 1998 1998;45:785 - 8.

37. Rolls K, Smith K, Jones P, Tuipulotu M, Butcher R, Kent B, et al. Suctioning an Adult with a Tracheal Tube N.S.W. Health Statewide Guidelines for Intensive Care New South Wales Intensive Care Coordination and Monitoring Unit. [Systematic review]. 2007.

38. Jayasekara R. Clinical Inquiry. Joanna Briggs Institute, Adelaide.; 2009.

39. Almgren B. Endotracheal suction - do it right or close the lung. Clinical Window ; International Web Journal for Medical Professionals 2008(24).

40. Larsson A. Inhale,suction and close the lung: a common clinical practice in Scandinavian intensive care units. Acta Anaesthesiologica. [Editorial]. 2009;53:699-700.

41. Huilgol RR. Flow through a Catheter. Flinders University South Australia.; 2010.

42. Worthley DLIG. Is endotracheal suctioning an art or a science? Critical Care and Resuscitation [Editorial Comment]. 2001;3:221-9. 
43. Yeh H-C, Schum GM. Models of human lung airways and their application to inhaled particle deposition. Bulletin of Mathematical Biology. 1980;42:461-80.

44. Spence K, Gilles D, Waterworth L. Deep versus shallow suction of endotracheal tubes in ventilated neonates and young infants. The Cochrane Library. [Cochrane Review]. 2003(1).

45. Almgren B. Endotracheal Suction a Reopened Problem. Digital comprehensive summaries of Upsalla dissertations from the Faculty of Medicine 11. [Doctoral Dissertation]. 20052005.

46. Qin L, Andre C, Philippe C, Eric M, Lamine A, Jean-Dominique L-K, et al. A computed tomographic scan assessment of endotracheal suctioning induced bronchoconstriction in ventilated sheep. American Journal of Respiratory Critical Care Medicine. 2000;162:1898 = 904 .

47. Corley A, Coruana L, Barnett A. Open and closed suctioning result in significant lung derecruitment. Anaesthesia and Intensive Care. [Abstract. of randomised control study]. 2010;38(6).

48. Papadakos PJ, Lachmann B. The Open Lung Concept of alveolar recruitment can improve outcome in respiatory failure and ARDS

The MountSinai Journal of Medicine. 2002;69 (1 - 2).

49. Plum F, Dunning M. Techniques for minimizing trauma to the tracheobronchial tree after tracheotomy. The New England Journal of Medicine. 1956;254(5):193-200.

50. Brandstater B. Atelectasis following tracheal suction in infants. Anesthesiology. 1969(November):468-73.

51. Boutros AR. Arterial blood oxygenation before and afterendotracheal suctioning in the apneic patient. Anesthesiology. 1970;32(2):114-8.

52. Sackner M, Landa J, Greenelth N, Robinson M. Pathogenesis and prevention of tracheobronchial damage with suction procedure. Chest. 1973;64(3):284 - 90.

53. Kuzenski BM. Effect of negative pressure on tracheobronchial trauma. Nursing Research. 1978;27(4):260-3.

54. Baun MM, Frantz RA, Lindsay AM. Physiological determinants of a clinically successful method of endotracheal suction. Western Journal of Nursing Research. 1984;6(2):213-28.

55. Walsh JM, Vanderwarf C, Hoscheit D, Fahey PJ. Unsuspected hemodynamic alterations during during endotracheal suctioning. Chest. 1989;95(1):162-5.

56. Lindgren S. Open and Closed Endotracheal Suctioning. Experimental and human studies [Thesis] 2007. 
57. Sinclair S, Molthen R, Haworth S, Dawson C, Waters C. Airway strain during mechanical ventilation in an intact animal model. American Journal of Respiratory Critical Care Medicine. [quasi experimental observational]. 2007;176:786 - 94.

58. Egbert LD, Laver MB, Bendixen HH. Intermittent deep breaths and Compliance during anesthesia in man. Anesthesiology. 1963;24(1):58-60.

59. Fell T, Cheney FW. Prevention of hypoxia during endotracheal suctioning. Ann Surg. 1972;174(1):24-8.

60. Cereda M, Villa F, Columbo E, Greco G, Nacoti M, Presenti A. Closed system endotracheal suctioning maintains lung volume during volume controlled mechanical ventilation. Intensive Care Medicine. 2001;27:648-52.

61. Frengley RW, Closey DN, Sleigh JW, Torrance Jm. The Effect of Closed System Suction on Airway Pressures when using Servo 300 Ventilator. Critical Care and Resuscitation. 2001;3:230 - 5. 62. Dyhr T, Bonde J, Larrson A. Lung recruit manoeuvres are effective in regaining lung volume after open endotracheal suctioning in acute respiratory distress syndrome. Critical Care. 2002;7:55 - 62.

63. Maggiore $S$, al e. Prevention of Endotracheal Suction Induced Alveolar Derecruitment in Acute Lung Injury. American Journal of Respiratory Critical Care Medicine. 2003;167:1215-24. 64. Branson R, Campbell R, Chatburn R, Covington J. AARC Clinical Practice Guideline; Endotracheal suctioning of mechanically ventilated adults and children with artificial airways. RESPIRATORY CARE. 1993;38(5):500-4.

65. Fernandez M-d-M, Piacentini E, Blanch L, Fernandez R. Changes in lung volume with threesystems of endotracheal suctioning with and without preoxygenation in patients with mild to moderate lung failure. Intensive Care Medicine. 2004;30:2210-5.

66. Morrow B, Futter M, Argent A. Effect of endotracheal suction on lung dynamics in mechanically - ventilated paediatric patients. Australian Journal of Physiotherapy. 2006;52:121 6.

67. Heinze H, Sedemund-Adib B, Herringlake M, Gosch U, Eichler W. Functional residual capacity changes after different endotracheal suctioning methods. Anesthesia and Analgesia. 2008;107(3):941-4.

68. Frerichs I, Pulletz S, Elke G, Zick G, Weiler N. Electrical impedance tomography in acute respiratory distress syndrome. The Open Nuclear Medicine Journal. 2010;2:110-8.

69. Stone K, Bell S, Preusser B. The effect of repeated endotracheal suctioning on arterial blood pressure. Applied Nursing Research. 1991;4(4):152-64. 
70. Celik SS, Elbas NO. The standard of suction for patients undergoing endotracheal intubation. Intensive Crit Care Nurs. 2000 Jun;16(3):191-8.

71. Briassoulis G, Briassoulis P, Michaeloudi E, Fitrolaki D-M, Spanaki A-M, Briassouli E. The Effects of Endotracheal Suctioning on the Accuracy of Oxygen Consumption and Carbon Dioxide Production Measurements and Pulmonary Mechanics Calculated by Compact Metabolic Monitor. Anesthesia and Analgesia. 2009;109(3):873-9.

72. Seymour C, Cross B, Cooke C, Gallop R, Fuch B. Physiologic impact closed system endotracheal suctioning in spontaneously breathing patients receiving mechanical ventilation. Respiratory Care. 2009;54(3):367-74.

73. Soares-de-Paula LC, Ceccon MEJ. randomised comparitive analysis between two tracheal suction systems in neonates. Rev Assoc Med Bras. 2010;56(4):434-9.

74. Thambrian AK, Ripley SH. Observations on tracheal trauma following suction; an experimental study. British Journal of Anaesthesia. 1966;38:459-62.

75. Czarnik RE, Stone K, Everhart C, Preusser B. Differential effects of continuous versus intermittent suction on tracheal tissue. Heart and Lung. 1991;20(2):144-51.

76. Grivans C, Lindren S, Aneman A, Stenqvst O, Lundin S. A Scandinavian survey of drug administration through inhalation, suctioning and recruitment maneuvers in mechanically ventilated patients. Acta Anaesthesiologica. [prospective survey]. 2009 2009;53:710-6.

77. Stenqvist O, Lindgren S, Karason S, Sondergaard S, Lundin S. Warning! Sunctioning. A lung model evaluation of closed suctioning systems. Acta Anaesthesiologica Scandinavia. 2001;45:16772.

78. Craig RJ. Supporting respiratory function. In: Luckman KSaJ, editor. BASIC NURSING W B Saunders; 1979. 